\title{
Diyanet İşleri Başkanlığı ve Dinî Söylemi -Diyanet Gazetesi ve Diyanet Aylık Dergi Başyazıları Örnekleminde-*
}

Cenksu ÜÇER**

\section{Öz}

Bu çalışmada Diyanet İşleri Başkanlığının dinî söylemi, Diyanet Gazetesi ve Diyanet Aylık Dergide yer alan ve Diyanet İşleri Başkanlarının (Vekili ve Yardımcılarının) kaleminden çıkan Başyazılar çerçevesinde ele alınmaktadır. Cumhuriyet'e geçişte de mevcut idarî yapı içerisinde yer alan Başkanlık, din hizmetlerini kamu görevi olarak yürütmekle yükümlü tutulmuştur. Başkanlık süreç içerisinde kurulan farklı idarî birimler vasıtasıyla mevzuatın yükümlü tuttuğu görevleri yerine getirmektedir. Başkanlığın hizmet politikalarının ve hassasiyetlerinin Diyanet İşleri Başkanlarının dilinden kamuoyu ile paylaşıldığı malumdur. Diyanet İşleri Başkanları 1950'li yıllardan beri düzenli olarak yayımlanan süreli yayınlarda Başyazılar ile topluma mesajlarını sistematik olarak iletmektedir. Bu itibarla bu yazıda Diyanet Gazetesi ve Diyanet Aylık Dergi Başyazıları merkeze alınarak Başkanlığın dinî söylemi hakkında bazı değerlendirmelerde bulunulmuştur. Başkanlığın dinî söyleminde Kanunla kendisine tanınan yetkilere bağlı olarak şekillenen iman esasları ve bazı inançlar, ibadet hayatı, birlik ve beraberlik, ahlak ve sosyal hayat merkezli bir çerçevenin söz konusu olduğu; bununla birlikte ahlak ve sosyal hayata ait konulara dair mesajların daha çok ön plana çıtığı dikkat çekmektedir.

Anahtar Kelimeler: Diyanet İşleri Başkanlığı, Dinî Söylem, İnanç, İbadet, Ahlak, BirlikBeraberlik, Sosyal Hayat.

\footnotetext{
* Araştırma Makalesi. Makale Gönderim Tarihi: 13.11.2021 Makale Kabul Tarihi: 04.12.2021

Bu çalışmada Diyanet Gazetesi ve Diyanet Aylık Dergiye ait verilerin derlenmesi ve değerlendirilmesi bağlamındaki katkıları için Ankara Yıldırım Beyazıt Üniversitesi Sosyal Bilimler Enstitüsü Yüksek Lisans Öğrencileri Hatice Kübra Çelebi ve Büşra Zoba'ya teşekkür ederim.

DOI: https://10.52886/ilak.1022952

** Prof. Dr., Ankara Yıldırım Beyazıt Üniversitesi, İslami İlimler Fakültesi, Temel İslam Bilimleri Bölümü, Kelam ve Mezhepler Tarihi Anabilim Dalı

Prof Dr., Ankara Yıldırım Beyazıt University, Faculty of Islamic Sciences, Department of Kalam and History of Islamic Sects, cenksu.ucer@ybu.edu.tr; hcenksuucer@hotmail.com ORCID: 0000-0001-9874-2990
} 


\title{
Presidency of Religious Affairs and Religious Discourse -In the Sampling of Diyanet Gazetesi/Diyanat Newspaper and Diyanet Aylık Dergi/Diyanat Monthly Magazine Editorials-
}

\begin{abstract}
In this study, the religious discourse of the Presidency/Directorate of Religious Affairs is discussed within the framework of the Editorials published in the Diyanat Newspaper and the Diyanat Monthly Magazine and written by the President of Religious Affairs (Incl. Deputies and Assistants). The the Presidency/Directorate, which was included in the current administrative structure during the shifting of the Republic, was obliged to lead religious services as a public duty. The Presidency/Directorate fulfills the required duties by the legislation through different administrative units established within the process. It is wellknown that the service policies and sensitivities of the Directorate are shared with the public through the perspective of the President of Religious Affairs. The Presidency/Directorate of Religious Affairs has been conveying its messages to the society systematically through the periodicals published editorials, consecutively since the 1950s. Concerning, this article, some evaluations were made about the religious discourse of the Directorate by taking the Diyanat Newspaper and Diyanat Monthly Magazine Editorials to the centric consideration. In the religious discourse of the Directorate, there is a centric framework on the principles of faith and certain beliefs, the life of worship, unity and solidarity, morality and social life, which are shaped depending on the jurisdictive granted to it by the Law; however, it is noteworthy that messages about moral and social life issues become important and noticed by people.
\end{abstract}

Keywords: Presidency/Directoorate of Religious Affairs, Religious Discourse, Belief, Worship, Ethics, Unity and Solidarity, Social Life.

\section{Özet}

Bu çalışmada Diyanet İşleri Başkanlığının dinî söylemi, Diyanet Gazetesi ve Diyanet Aylık Dergide yer alan ve Diyanet İşleri Başkanlarının (Vekili ve Yardımcılarının) kaleminden çıkan Başyazılar çerçevesinde ele alınmaktadır. Gerek kurumların gerek dinî söylemin geçmişten tevarüs edilen bir takım hususiyetlerle birlikte dünyada ve yerelde yaşanan ve daima birbiriyle irtibatlı bir şekilde biçim alan siyasî, iktisadî, bilimsel, kültürel vb. gelişmelere göre ortaya çıktığı ya da şekillendiği hususunda şüphe yoktur. Bu itibarla Başkanlığın dinî söyleminin özellikle tarihî arka planının ortaya konulması adına İslam tarihinde gerek dindevlet ilişkileri gerek din hizmeti olgusu bağlamında dönemler, coğrafyalar ve devletler nezdindeki uygulamaların dikkate alınması gerektiği açıktır.

Türkiye Cumhuriyeti'nin, idare müesseselerinin mahiyetini ve bunların köklerini anlayabilmek için doğal olarak Cumhuriyet'ten önceki devirlerin, başta en yakın devlet tecrübesi olarak Osmanlı müesseselerinin bütününü mukayeseli bir 
şekilde gözden geçirmenin gerekliliği ortadadır. Zira Başkanlık, Osmanlı döneminin Şeyhülislamlık kurumunun adalet, eğitim, vakıflar ve din hizmetlerine dair yürüttüğü görevlerden sadece din hizmetine ait olanlarını belirli sınırlar içerisinde yürütmekle mükellef tutulmuştur.

Başkanlığın dinî söyleminde ülkemizde 20. yüzyıl sürecinde yaşanan siyasî, iktisadî, kültürel vb. gelişmelerin etkisi olması kaçınılmazdır. Ayrıca Başkanlığın yetki alanının belirlenmesi hususu bağlamında şer'î hukuk ve örfî hukuk olgusunun dikkate alınması gerektiği açıktır. Bununla birlikte -her ne kadar farklı çevrelerde değişik zamanlarda Eş‘arîlik etkisi olduğu bilinse de- gerek dinî anlayış olarak gerek Orta Asya'dan Anadolu'ya coğrafya olarak büyük oranda Hanefî-Mâturidî kültür havzası ile hemhal olmanın neticesinde bu gerçekliğin de dinî söyleme ana unsur haliyle tesir edeceği şüphesizdir.

Cumhuriyet'e geçişte de mevcut idarî yapı içerisinde yer alan Başkanlık din hizmetlerini kamu görevi olarak yürütmekle yükümlü tutulmuştur. Başkanlık süreç içerisinde kurulan farklı idarî birimler vasitasıyla mevzuatın yükümlü tuttuğu görevleri yerine getirmektedir. Diyanet İşleri Başkanlarının konuşmaları, basın açıklamaları, değişik vesilelerle yayımladıkları mesajlar başta olmak üzere, kurulduğu günden bugüne varlığını devam ettiren Din İşleri Yüksek Kurulunun kararları, mütalaaları, fetvaları ve görüşleri, hutbeler, vaazlar, basılı-süreli vb. yayınlar Başkanlığın dinî söylemi açısından ayrı ayrı ele alınması gerekli unsurlardır.

Bununla birlikte Başkanlığın hizmet politikalarının ve hassasiyetlerinin Diyanet İşleri Başkanlarının dilinden kamuoyu ile paylaşıldığı malumdur. Diyanet İşleri Başkanları 1950'li yıllardan beri düzenli olarak yayımlanan süreli yayınlarda Başyazılar ile topluma mesajlarını sistematik olarak iletmektedir. Bu itibarla bu yazıda Diyanet Gazetesi ve Diyanet Aylık Dergi Başyazıları merkeze alınarak Başkanlığın dinî söylemi hakkında bazı değerlendirmelerde bulunulmuştur.

Başkanlığın dinî söyleminde kanunla kendisine tanınan yetkilere bağlı olarak şekillenen iman esasları ve bazı inançlar, ibadet hayatı, birlik ve beraberlik, ahlak ve sosyal hayat merkezli bir çerçevenin söz konusu olduğu; bununla birlikte ahlak ve sosyal hayata ait konulara dair mesajların daha çok ön plana çıtığı dikkat çekmektedir.

Diyanet Gazetesi Başyazılarının 4 adetinin $(\% 1,4)$ iman esasları ve inanç konuları, 18 adetinin $(\% 6,4)$ ibadetler, 5 adetinin $(\% 1,8)$ ahlak, 18 adetinin $(\% 6,4)$ birlik ve beraberlik, 232 adetinin $(\% 83,7)$ de dinî sosyo-kültürel hayatla ilgili olduğu görülmektedir. Diyanet Gazetesi Başyazılarının konularının ilgili başlıklara taksimi sonucunda ortaya çıkan bu tablo, Başyazıların 22'sinin (\%8) iman esasları ve inanç konuları ile ibadetler ve ibadet hayatı hakkında iken; 255'inin doğrudan ahlak kelimesini içermek suretiyle ahlak, birlik ve beraberlik ve dinî sosyo-kültürel hayatla ilgili olmak üzere toplamda \% 92'lik yüksek bir oranla genel kategori olarak ahlak alanını ilgilendiren bir çerçevede olduğunu göstermektedir. 
Buna yakın bir çerçeve gerek Diyanet Aylık Dergi'nin gerek Başyazılarının gündemleri ve konuları bağlamında da söz konusudur. Diyanet Aylık Dergi'nin gündem konularına göz atıldığında fizikî ve internet ortamında ulaşılabilen 360 sayıdan 15 adetinin (\%4) iman esasları ve inanç konuları, 25 adetinin (\%7) ibadetler, 16 adetinin (\%4,5) ahlak, 33 adetinin (\%9) birlik ve beraberlik, 271 adetinin $(\% 75,5)$ ise dinî sosyo-kültürel hayat ve aktüel konularla ilgili olduğu anlaşılmaktadır. Bu durumda Diyanet Aylık Dergi gündem konularının 40 adeti (\%11) iman esasları ve inanç konuları ve ibadetler hakkında iken; 320 adeti doğrudan ahlak kelimesini içermek üzere ahlak, birlik ve beraberlik, dinî sosyo-kültürel hayatla ilgili olmak üzere toplamda \% 89'luk yüksek bir oranla genel kategori olarak ahlak alanını ilgilendiren bir çerçevede olduğu görülmektedir.

Diyanet Aylık Dergi'nin 2021 Ağustos itibariyle neşredilen 360 Başyazısının konu dağılımları Dergi gündemlerindeki konu dağılımına yakındır. Buna göre Başyazıların 12 adeti (yaklaşık \%3,4) iman esasları ve inanç konuları, 28 adeti (yaklaşık \%7,8) ibadetler, 14 adeti (yaklaşık \%3,8) ahlak, 32 adeti (yaklaşık \%8,8) birlik ve beraberlik, 274 adeti (yaklaşık \%76) dinî sosyo-kültürel hayat ve aktüel konularla ilgilidir. Buna göre Diyanet Aylık Dergi'nin Başyazıların (360) 40 adeti (yaklaşık \%11) iman esasları ve inanç konuları ile ibadetler hakkında iken; 320'si ahlak, birlik ve beraberlik, dinî sosyo-kültürel hayatla ilgili olmak üzere toplamda yaklaşık \% 89'lik yüksek bir oranla genel kategori olarak ahlak alanını ilgilendiren bir çerçevede olduğu görülmektedir.

Neticede Diyanet İşleri Başkanları kaleme aldıkları Başyazılarda \%90’lara varan bir oranda sosyal içerikli yazılar kaleme almıştır. Bu durumda din söylemi, din üzerine konuşmak bağlamında dinin ana öğretisinin tanıtımı ve hâdiseleri dinle ilişkilendirmek kapsamında dinin dolaylı ilgi alanlarının tespiti ya da üretilmesi açısından değerlendirildiğinde, Başkanlığın din söyleminin iman esasları ve ibadet hayatı ile beraber dinin sosyal hayatın pek çok farklı alanıyla ilgili mesajını kamuoyu ile paylaşma yoluna gittiği görülmektedir. Bu, Başkanların ve Başkanlığın İslâm dininin ilgi alanı hakkında sosyal alanı dikkate alan bir yaklaşım ve sosyal ahlakı inşaya dönük fiilî bir tavır sergilediklerini ortaya koymaktadır.

\section{Summary}

In this study, the religious discourse of the Presidency/Directorate of Religious Affairs is discussed within the framework of the Editorials published in the Diyanat Newspaper and the Diyanat Monthly Magazine and written by the President of Religious Affairs (Incl. Deputies and Assistants). Political, economic, scientific, cultural, etc. which are lived in the world and domestically and always take shape in connection with each other, together with some inherited characteristics of the both institutions and religious discourse. There is no doubt that it emerged or was shaped according to the developments. Concerning, in order to reveal the historical background of the Directorate's religious discourse, it is clear that the practices in the 
context of religion-state relations and religious service in Islamic history should be taken into account in terms of periods, geographies, and states.

In order to understand the nature of the administrative institutions of the Republic of Turkey and their roots, it is naturally necessary to review all of the Ottoman institutions in a comparative way, as the most recent state experience of the periods before the Republic. Because the Directorate was obliged to lead only those of the religious service within certain limits among the duties carried out by the Sheikhul-Islam institution of the Ottoman era regarding justice, education, foundations, and religious services. In the religious discourse of the Directorate, political, economic, cultural, etc. experienced in our country during the 20th century. It is inevitable that developments will have an impact. In addition, it is clear that the phenomenon of Shariah law and consuetudinary law should be taken into account in the context of determining the jurisdiction of the Directorate. However, although it is known that there was an influence of Asharite school in different spheres at different times, this reality is also the main element in religious discourse, as a result of being in contact with the Hanafi-Maturidi cultural area to a large extent, the both in terms of religious understanding and geography from Central Asia to Anatolia. No doubt it will have an effect.

The Directorate, which was included in the existing administrative structure during the shifting of the Republic, was held responsible for leading religious services as a public duty. The Directorate fulfills the duties required by the legislation through different administrative units established during the process. The decisions, opinions, fatwas and dictums, printed-periodicals sermons, preaches, etc. of the High Board of Religious Affairs, which has been in existence since its establishment, especially the speeches of the Presidents of Religious Affairs, press statements, messages published on different occasions. Publications are elements that need to be dealt with separately in terms of the Directorate's religious discourse.

However, it is known that the service policies and sensitivities of the Directorate are shared with the public through the language of the President of Religious Affairs. The Presidents of Religious Affairs have been conveying its messages to the society systematically through the periodicals published editorials, consecutively since the 1950s. Concerning, this article, some evaluations were made about the religious discourse of the Presidency by taking the Diyanat Newspaper and Diyanat Monthly Magazine Editorials to the centric consideration.

In the religious discourse of the Directorate, there is a centric framework on the principles of faith and certain beliefs, the life of worship, unity and solidarity, morality and social life, which are shaped depending on the jurisdictive granted to it by the Law; however, it is noteworthy that messages about moral and social life issues become important and noticed by people. 
Of the Diyanat Newspaper Editorials, $4(1.4 \%)$ were based on the principles of faith and belief issues, $18(6.4 \%)$ were prayers/worships, $5(1.8 \%)$ were ethics, 18 $(6.4 \%)$ were unity and solidarity, 232 It is seen that the number of customs $(83.7 \%)$ is related to religious socio-cultural life. This table, which emerged as a result of the division of the topics of the Diyanat Newspaper Editorials into the relevant headings, shows that 22 of the editorials (8\%) are about the principles of faith, belief issues, worship and worship life; By including the word morality/ethics directly, 255 of them are related to morality, unity and solidarity, and religious socio-cultural life, with a high rate of $92 \%$ in total, showing that they are in a framework that concerns the field of morality/ethics as a general category.

A similar framework exists in the context of the agendas and topics of both the Diyanat Monthly Journal and the Editorials. When we look at the agenda and topics of the Diyanat Monthly Magazine, 15 (4\%) of the 360 issues that can be accessed physically and on the internet are principles of faith and belief topics, $25(7 \%)$ are worship, 16 (4.5\%) are morals, $33(4 \%)$ 9) unity and solidarity, 271 (75.5\%) of them are related to religious, socio-cultural life and current issues. At that rate, while 40 $(11 \%)$ of the agenda topics of the Diyanat Monthly Magazine are about the principles of faith, belief issues and worship; It is seen that it is in a framework that concerns the field of morality as a general category, with a high rate of $89 \%$ in total, 320 of which are directly related to morality, unity and solidarity, and religious sociocultural life.

The distribution of topics in the 360 Editorials of Diyanat Monthly Magazine published as of August 2021 is close to the distribution of topics on the agenda of the Journal. According to this, 12 of the editorials (approximately 3.4\%) were on the principles of faith and belief, 28 (approximately $7.8 \%$ ) were prayers/worship, 14 (approximately 3.8\%) were morals, and 32 (approximately 8.8\%) were unity. and solidarity, 274 of them (about $76 \%$ ) are related to religious, socio-cultural life and current issues. According to this, 40 of the editorials (360) of the Diyanat Monthly Magazine (about 11\%) are about the principles of faith, belief issues and worship; It is seen that it is in a framework that concerns the field of morality as a general category, with a high rate of $89 \%$ in total, 320 of which are related to morality, unity and solidarity/togetherness, and religious socio-cultural life.

And consequently, the Presidents of Religious Affairs wrote up to $90 \%$ of social content in their editorials. At that, when the religious discourse is evaluated in terms of the identification or production of indirect interests of religion within the scope of promoting the main teaching of religion and associating events with religion in the context of talking about religion, the Directorate's religious discourse, appears to be in the way of sharing, along with the principles of faith and religious life, as well as the message of religion in many different areas of social life, is shared with the public. This reveals that the Presidents and the Directorate exhibit an approach that takes into account the social field about the interest of the religion of Islam and an active demeanor towards building the social morality. 


\section{Giriş}

Bu çalışmada, Diyanet Gazetesi ve Diyanet Aylık Dergide yer alan ve Diyanet İşleri Başkanlarına (bazısı Vekilleri ve Yardımcılarına) ait Başyazılar üzerinden Diyanet İşleri Başkanlığının dinî söylemi ele alınmaktadır. Hem kurumların hem dinî söylemin gerek dünyada gerek yerelde yaşanan ve daima birbiriyle irtibatlı bir şekilde biçim alan siyasi, iktisadi, bilimsel, kültürel vb. gelişmelere göre ortaya çıtığ 1 ya da şekil aldığında şüphe yoktur. Cumhuriyet'e geçişte de Başkanlığa mevcut idari yapı içerisinde yer verilmiş ve kurum din hizmetlerini kamu görevi olarak yürütmekle yükümlü tutulmuştur. Dolayısıyla Başkanlığın Cumhuriyet tarihinde başlangıçtan bugüne geçirdiği süreçleri dikkate almak konumuzun çerçevesi açısından son derece önemlidir. Ancak, Başkanlığın hem kurumsal yapısı hem yetkileri hem de hizmet alanlarının sağlıklı değerlendirilmesi için tevarüs etmiş olduğu birtakım unsurları mutlaka dikkate almak gerekmektedir. Bu itibarla Cumhuriyet öncesinde gerek bu topraklarda kurulmuş devletlerin gerek irtibatlı oldukları coğrafyalarda kurulan devletlerin idari yapısı, bu idari yapı içerisinde kurgulanmış din-devlet ilişkileri; dinî anlayış ve yapılar ile yürütülen din hizmetlerinin beraberce göz önünde bulundurulması kaçınılmazdır.

Başkanlığın dinî söylemini ele alan bir çalışmada, kuruluşundan bugüne Başkanlık bünyesinde yer alan farklı birimlerin faaliyetlerinin ayrı ayrı incelenmesi gerektiği açıktır. Bu bağlamda Diyanet İşleri Başkanlarının konuşmaları, basın açıklamaları, çeşitli vesilelerle yayımladıkları mesajlar, Din İşleri Yüksek Kurulunun kararları, mütalaaları, fetvaları, hutbeler, Kurul onayından geçerek yayımlanan vaaz kitapları, basılı yayınlar, süreli yayınlar ayrı ayrı; hatta kendi içinde de dünyada ve ülkede yaşanan siyasal, sosyo-ekonomik ve kültürel gelişim ve değişimler, bu gelişim ve değişimlerin yaşandığı ana zaman aralıkları, mevzuatta yaşanan değişiklikler ya da görev alan Başkanların hizmet anlayışları vb. farklı ölçeklerde değerlendirmeye tabi tutulabileceğinde şüphe yoktur. Bu çalışmada konu, makale sınırlılıkları dikkate alınarak ve Başkanlığın hizmet politikalarının ve hassasiyetlerinin Diyanet İşleri Başkanlarının dilinden sistematik bir şekilde kamuoyu ile paylaşıldığı gerçeğinden hareketle Başkanların Diyanet Gazetesi ve Diyanet Aylık Dergide yer alan Başyazıları ${ }^{1}$ merkeze alınarak sınırlandırılmıştır.

\section{Diyanet İşleri Başkanlığı: Kuruluş ve Temel Görevlerine Dair Kısa Tarihçe}

03 Mart 1924 yılında kurulan Diyanet İşleri Reisliğinin/Başkanlığının o günden bugüne kanunla belirlenen ortak temel görevi "İslam Dininin inançları ve ibadetleri ile ilgili işleri yürütmek ve ibadet yerlerini yönetmek”tir. Kanun

\footnotetext{
${ }^{1}$ Diyanet Gazetesi'nde Gazete'nin başlık kısmında Başyazı olarak belirlenen yazıların devam sayfalarında bazen Başmakale ifadesinin kullanıldığı görülmektedir.
} 
maddelerinde hâlihazırda yer alan "ahlak esasları" ibaresi ve "din konusunda toplumu aydinlatmak" görevleri ile "laiklik ilkesi doğrultusunda", "bütün siyasi görüş ve düşünüşlerin dişında kalarak" ve "milletçe dayanışma ve bütünleşmeyi amaç edinerek" görevlerini yerine getireceği çerçevesindeki ilkeler, ülkedeki gelişmelere bağlı olarak zaman içerisinde kanun maddelerine eklenmiştir. Nitekim Diyanet İşleri Reisliği'nin 03 Mart 1924 tarihli ve 429 sayılı "Şeriye ve Evkâf ve Erkânı Harbiyei Umumiye Vekâletlerinin İlgasına Dair" Kuruluş Kanunu'nda "İslam Dininin inançları ve ibadet esasları ile ilgili işleri yürütmek ve ibadet yerlerini yönetmek" görevleri yer alırken; "ahlak esasları" ve "din konusunda toplumu aydınlatmak" görevi ve "laiklik ilkesi doğrultusunda", "bütün siyasi görüş ve düşünüşlerin dışında kalarak" ve "milletçe dayanışma ve bütünleşmeyi amaç edinerek" hükümlerine yer verilmemiştir. ${ }^{2}$ İlgili Kanun'un 1. maddesi şu şekildedir: “Türkiye Cumhuriyeti'nde muamelât-ı nâsa dair olan ahkâmın teşri ve infazı, Türkiye Büyük Millet Meclisi ile onun teşkil ettiği Hükûmete ait olup dini mübini İslâm'ın bundan maada itikadat ve ibadata dair bütün ahkâm ve mesâilinin tedviri ve müessesatı diniyenin idaresi için Cumhuriyet'in makarrında bir Diyanet İşleri Reisliği makamı tesis edilmiştir."3

Diyanet İşleri Reisliği teşkilat ve vazifeleri hakkındaki 2800 sayılı Kanun 14 Haziran 1935 tarihinde kabul edilmiş ve 22 Haziran 1935 tarihli ve 3035 sayılı Resmî Gazetede yayımlanmıştır. ${ }^{4}$ Bu Kanun'un 2. maddesi uyarınca çıkarılan ve Reisliğin görevlerini belirleyen 7647 sayılı Diyanet İşleri Reisliği Teşkilatı'nın Vazifelerini Gösterir Nizamname ise 11 Kasım 1937 tarihlidir. ${ }^{5} 03$ Mart 1950 tarihinde kabul edilen 5634 sayılı Kanun ile kurumun adı, Diyanet İşleri Başkanlığı olmuştur. İlgili Kanun ile kurumdaki mevcut birimler yeniden yapılandırılarak isimlendirilmiş ve kurumun teşkilat yapısına yeni birtakım birimler ve görevler eklenmiştir. ${ }^{6}$

154. maddesinde "Genel idare içerisinde yer alan Diyanet İşleri Başkanlığı, özel kanununda gösterilen görevleri yerine getirir." 7 ifadeleriyle 1961 Anayasası'nda yer verilen Başkanlığa, 1982 Anayasası'nda da yer verilmiş ve ilgili Anayasa'nın 136. maddesi şu şekilde düzenlenmiştir: “Genel idare içinde yer alan Diyanet İşleri

\footnotetext{
2429 sayılı Kuruluş Kanunu'nda zikredilmeyen ve kanun maddesinde ancak 1965 tarihinde kabul edilen 633 sayılı Kanun'la yer alan "toplumu din konusunda aydınlatma” görevi, aslında 2800 sayılı Diyanet İşleri Reisliği Teşkilât ve Vazifeleri Hakkında Kanun gereğince çıkarılan 11 Teşrinisani 1937 tarihli ve 7647 sayılı Diyanet İşleri Reisliği Teşkilâtı'nın Vazifelerini Gösterir Nizamname’ de yer almıştır. İştar Gözaydın, Diyanet Türkiye Cumhuriyeti'nde Dinin Tanzimi (İstanbul: İletişim, 2020), 113.

${ }^{3}$ Kuruluşundan Günümüze Diyanet Işsleri Başkanliğı Tarihçe-Teşkilat-Hizmet ve Faaliyetler (1924-1997) (Ankara: Diyanet İşleri Başkanlığı Yayınları, 1999), 21; Nihat Aytürk vd., “Diyanet İşleri Başkanlığı Teşkilat Tarihçesi”, Diyanet İlmi Dergi 15/1 (1989), 31. Söz konusu Kanun metninin Şeriye ve Evkâf Vekâleti'nden Başkanlığa geçiş açısından ne anlama geldiği hakkında bk. Gözaydın, Diyanet, 15-16, 59-62.

${ }^{4}$ Diyanet İşleri Reisliği Teşkilat ve Vazifeleri Hakkındaki Kanun, Resmî Gazete 3035 (22 Haziran 1935), Kanun No: 2800, (5376-5377).

${ }^{5}$ Gözaydın, Diyanet, 113.

${ }^{6}$ Kuruluşundan Günümüze Diyanet Işsleri Başkanlığı, 21-25; Nihat Aytürk vd., “Diyanet İşleri Başkanlığ1 Teşkilat Tarihçesi", 32-33.

7 T.C. Anayasa (1961), Resmî Gazete 10859 (20.07.1961), Kanun No: 334, m. 154 (4653).
} 
Başkanlığı, laiklik ilkesi doğrultusunda, bütün siyasi görüş ve düşünüşlerin dışında kalarak ve milletçe dayanışma ve bütünleşmeyi amaç edinerek, özel kanununda gösterilen görevleri yerine getirir." 1982 Anayasası'nda Başkanlığın görev şekli ve amaçları daha da genişletilip belirginleştirilerek kurumun "laiklik ilkesi doğrultusunda, bütün siyasî görüş ve düşünüşlerin dışında kalarak ve milletçe dayanışma ve bütünleşmeyi amaç edinerek" hizmetlerini yürüteceği hükme bağlanmıştır. ${ }^{9}$

1961 Anayasası'nın 154. maddesinde işaret edilen Başkanlığın 633 sayılı Özel Kanunu, 22 Haziran 1965 tarihinde yürürlüğe girmiştir. Bu Kanun'la Başkanlığın görevleri büyük oranda bugünkü mevcut halini almış ve 1924'teki Kuruluş Kanunu'nun metnine "ahlak" ibaresi ${ }^{10}$ ve "toplumu din konusunda aydınlatma" hükmü ilave edilerek şu şekilde düzenlenmiştir: "İslam Dininin inançları, ibadet ve ahlak esasları ile ilgili işleri yürütmek, din konusunda toplumu aydınlatmak ve ibadet yerlerini yönetmek üzere Başbakanlığa bağlı Diyanet İşleri Başkanlığı kurulmuştur." 1113 Temmuz 2010 tarihli ve 27640 sayılı Resmî Gazetede yayımlanan 01 Temmuz 2010 tarihli ve 6002 sayılı Diyanet İşleri Başkanlığı Kuruluş ve Görevleri Hakkında Kanun ile Bazı Kanunlarda Değişiklik Yapılmasına Dair Kanun ${ }^{12}$ ile Başkanlık hakkında geniş bir düzenleme yapılmış; bu düzenlemelere göre Başkanlık müsteşarlık düzeyinde yapılandırılmış, hizmet birimleri artırılmış, cami dışı alanlarda hizmet yürütebilmesinin önü açılmış, uluslararası alanda yürüttüğü hizmetler yasal alt yapıya kavuşturulmuş, radyo ve televizyon kurması gibi pek çok yeni hizmet alanı imkanı verilmiştir. ${ }^{13}$ Cumhurbaşkanlığı Hükümet Sistemi'ne geçilmesiyle birlikte Başkanlık Cumhurbaşkanlığı'na bağlanmış ve bu çerçevede Kanun'da yer alan "Başbakanlığa" ibaresi, 02 Temmuz 2018 tarihli ve 703 sayılı KHK'nin 141'inci maddesiyle "Cumhurbaşkanlığına" şeklinde değiştirilmiş, ilgili KHK ve müteakip diğer kanuni düzenlemeler ile dijital yayıncılık, Kuran-ı Kerîm meâllerini incelemek, öğrenci yurtları, eğitim kurumları, ceza infaz kurumları vb. farklı kurumlarla işbirliği yapmak suretiyle buralarda manevi danışmanlık ve din hizmetleri yürütmek, yine göçmen, engelli, bağımlı vb. desteğe muhtaç kesimlere manevi danışmanlık hizmeti vermek, ihtiyaç duyulan yerlerde okuma salonu, gençlik merkezi vb. yerler açmak, müftülükler marifetiyle nikah kıymak gibi

\footnotetext{
${ }^{8}$ T.C. Anayasa (1982), Resmî Gazete 17863 (Mükerrer) (09.11.1982), Kanun No: 2709, m. 136 (39).

${ }^{9}$ Başkanlık teşkilatı ile ilgili yapılan hukuki düzenlemeler hakkında bkz. Gözaydın, Diyanet, 62-92.

10 İsmail Kara, "Din ile Devlet Arasında Sıkışmış Bir Kurum: Diyanet İşleri Başkanlığı", Marmara Üniversitesi İlahiyat Fakültesi Dergisi 18 (2000), 39-40. Ayrıca bkz. Bahset Karslı, "Cumhuriyet Dönemi Din-Siyaset Tartışmaları: Ahmet Hamdi Akseki Örneği", Turkish Studies Türkoloji Araştırmaları 9/5 (2014), 279-1298.

${ }^{11}$ Diyanet İşleri Başkanlığı Kuruluş ve Görevleri Hakkında Kanun (DİB Kanun), Resmî Gazete 12038 (2 Temmuz 1965), Kanun No: 633, m.1.

${ }_{12}$ Diyanet İşleri Başkanlığı Kuruluş ve Görevleri Hakkında Kanun ile Bazı Kanunlarda Değişiklik Yapılmasına Dair Kanun (DiB Değişiklik Kanun), Resmî Gazete 27640 (13.07.2010), Kanun No: 6002.

${ }_{13}$ Ömür Aydın, “Diyanet İşleri Başkanlığının Hukuki Statüsü Üzerine Tartışmalar”, Akademik İncelemeler Dergisi 14/2 (2019), 268.
} 
Başkanlığın hizmet alanlarının geliştirilip genişletilmesini de muhtevi bir takım düzenlemeler yapılmıştır. ${ }^{14}$

\section{Tevarüs Edilen Kurumsal Tecrübe}

Diyanet İşleri Reisliği/Başkanlığı, kuruluş aşamasından bugünlere hakkında daima sıcak ve yoğun tartışmaların yaşandığı bir kurum olma hüviyetini taşımaktadır. Kuruluş aşamasında daha çok isimlendirilmesi, yetki ve hizmetleri bağlamında yürütülen tartışmaların, ${ }^{15}$ ilerleyen süreçlerde çoğunlukla kurumun statüsü, özerkliği ve temsil sorunu gibi farkı alanlarda yoğunlaştığg görülmektedir. ${ }^{16}$ Başkanlık hakkında yapılan çalışmaların doğal ve haklı olarak en yakın kurumsal tecrübe olan Osmanlı Devletinin teşkilat yapısı içerisinde yer alan Şeyhülislâmlık/Meşihât-ı İslâmiyye kurumunu merkeze alarak yürütüldüğü dikkat çekmektedir. ${ }^{17}$ Zira bir Cumhuriyet kurumu olarak Reislik/Başkanlık, Osmanlı döneminde süreç içerisinde Şeyhülislâmlık kurumunun icra ettiği adalet, eğitim, vakıflar ve din hizmeti alanlarındaki görevlerinden sadece din hizmeti alanında görev icra etmek üzere yetkilendirilmiştir. ${ }^{18}$ Bugün Türkiye Cumhuriyeti'nin genel idare yapılanması dikkate alındığında ise Adalet Bakanlığı, Millî Eğitim Bakanlığı, Diyanet İşleri Başkanlığı, YÖK, Vakıflar Genel Müdürlüğü vb. pek çok kurumun yürüttüğü görevlerin dönemi itibariyle Şeyhülislâmlık/Meşihât kurumu tarafından ifa edildiği görülmektedir. ${ }^{19}$

Reisliğin/Başkanlığın Cumhuriyet dönemiyle beraber görev alanının din hizmetiyle sınırlandırılması hususunun sağlıklı bir şekilde değerlendirilmesi adına konunun farklı yönlerini dikkate alarak gerek din-devlet ilişkileri gerek din hizmeti olgusu bağlamında dönemler, coğrafyalar ve devletler nezdindeki uygulamaların dikkate alınması gerektiği açıktır. İslâm tarihinde din-devlet ilişkisi ve

\footnotetext{
${ }^{14}$ Anayasada Yapılan Değişikliklere Uyum Sağlanması Amacıyla Bazı Kanun ve Kanun Hükmünde Kararnamelerde Değişiklik Yapılması Hakkında Kanun Hükmünde Kararname (KHK 703), Resmî Gazete 30473 (3. Mükerrer) (09 Temmuz 2018), KHK No: 703, m. 141.

${ }^{15}$ Kuruluş Kanunu'nda dinî yayın yapması hakkında herhangi bir hüküm bulunmamasına rağmen Başkanlığın kurulduğu yıla ait ilk bütçesi (1924) ile ikinci bütçesi (1925) hakkında Türkiye Büyük Millet Meclisi'nde yapılan görüşmelerde Diyanet İşleri Reisliği/Başkanlığı'nın dinî eser telif etmesi gerektiği hakkında ileri sürülen görüşler bu durumu teyit etmektedir. Mehmet Bulut, "Diyanet İşleri Reisliği (Başkanlığı) 1341 (1925) Malî Yılı Bütçe Müzakereleri”, Diyanet Illmi Dergi 36/1 (2000), 102-125.

${ }^{16}$ Aydın, “Diyanet İşleri Başkanlığının Hukuki Statüsü Üzerine Tartışmalar”, 240-253.

${ }^{17}$ Remzi Kaya, Sosyolojik Açıdan Türkiye'de Din-Devlet İlişkileri ve Diyanet İşler Başkanlığı (İstanbul: İstanbul Üniversitesi, Sosyal Bilimler Enstitüsü, Doktora Tezi, 1994), 85-94; Kemalettin Taş, Türk Halkının Gözüyle Diyanet (İstanbul: İz Yayıncillk, 2002), 67-85.

18 Davut Dursun, Yönetim-Din İlişkileri Açısından Osmanlı Devletinde Siyaset ve Din (İstanbul: İşaret Yayınları, 1992), 263-311; Kemalettin Taş, “Osmanlı Yönetim Sisteminde Şeyhülislâmlık Kurumu Sosyolojik Bir Çözümleme-", Süleyman Demirel Üniversitesi Sosyal Bilimler Enstitüsü Dergisi 1/1 (2005), 8792; Seyfettin Erşahin, “Bir Cumhuriyet Kurumu Olarak Diyanet İşleri Başkanlığının Tarihi Kökeni (Ümmet Yapısından Millet Yapısına)", Din Hizmetleri ve Din Eğitiminde Türkiye Tecrübesi (Ankara: Diyanet İşleri Başkanlığı Yayınları, 2019), 36, 38-40.

19 İrfan Yücel, “Diyanet İşleri Başkanlığının Tarihçesi”, Diyanet Aylık Dergi 41 (1994), 17.
} 
kurumsallaşmış bir din hizmeti bağlamında başta Hz. Peygamber (s.a.s) döneminden başlayarak ilk dört halifeyi ifade eden Hülefâ-i Râşidîn dönemi, Emevîler, Abbâsîler, Selçuklular, Osmanlılar ve Cumhuriyet dönemlerine ve bu dönemlerdeki gelişmelere genel hatlarıyla göz atmak yerinde olacaktır. ${ }^{20}$

Din-devlet ilişkileri bağlamında gerek dünyada gerek İslâm dünyasında pek çok farklı uygulamanın bulunduğu bir gerçeklikte ${ }^{21}$ bu noktada öncelikle değinilmesi gereken husus, Kur'an'da ve hadislerde devlet ve yönetim şekli hakkında belirleyici, sabit ve değiştirilemez hükümlerin yer almaması; yerine şûra, liyakat, işin ehline verilmesi, hakk ve adalet üzere olma, zulme engel olma, İslâm'ın kurallarına uyma gibi kaidelere yer verilmesi, bu hususun Müslümanlara bırakılmış olduğunu göstermektedir. ${ }^{22} \mathrm{~Hz}$. Peygamber'den sonra devlet idaresini üstlenen İlk Dört Halife' nin her birinin farklı şekillerde halifelik görevine getirilmesi ${ }^{23} \mathrm{ve}^{\text {"halife", }}$ "emir" ve "imam" gibi farklı unvanlarla anılmalar ${ }^{24}$ Müslüman toplumun ilk zamanlardan itibaren yönetim işini kendi coğrafyalarındaki yerleşik kabul ve uygulamalar ile o zamandaki -hatta andaki- şartlara göre şekillendirdiğinin en bariz göstergelerinden biridir. İslâm tarihinde Hz. Peygamber'den bugünlere din-devlet ilişkileri hakkındaki pratik çerçeve de bu durumu teyit etmektedir.

Hilafetin kurumsallaşmasında İlk Dört Halife döneminden itibaren farklı tarz1 siyasetler ${ }^{25}$ söz konusu olmakla birlikte bu kurumsallaşmanın İlk Dört Halife'den Osmanlı'ya kadar da farklı biçimlerde olduğu görülmektedir. Bilindiği üzere Hz. Peygamber döneminde gerek din gerek devlet işleri Hz. Peygamber (s.a.s) tarafından yürütülmüş, dolayısıyla din ve devlet işleri birbirinden ayrılmamıştır. Aynı durum

\footnotetext{
${ }^{20} \mathrm{Bu}$ noktadaki genel bir tarihlendirme için bak. Hasan Yavuzer, Çağdaş Din Hizmeti ve Diyanet İşleri Başkanlı̆̆ı-Dini Otorite ve Teşkilatların Sosyolojik Analizi (Kayseri: Laçin Yayınları, 2006), 31-49.

${ }^{21}$ Ejder Okumuş, “Din-Devlet İlişkilerine Meşruiyet Kavramı Etrafında Bir Yaklaşım”, Marife: Dini Araştırmalar Dergisi 1/3 (2002), 12-28; Osman Zahid Çifçi, "Batı'da Din-Devlet İlişkilerinde Ortaya Çıkan Dönemler", ISTEM: İslâm Sanat, Tarih, Edebiyat ve Musikisi Dergisi 10/19 (2012), 195-207; İsmail Kaya, "Makrososyolojik Perspektife Göre İslâm Tarihinde Din ve Devlet İlişkisi Modelleri", Tokat İlmiyat Dergisi [Gaziosmanpaşa Üniversitesi İlahiyat Fakültesi Dergisi] 8/1 (2020), 403-428.

${ }^{22}$ Casim Avcı, "Hilâfet", Türkiye Diyanet Vakfi İslâm Ansiklopedisi (İstanbul: TDV Yayınları, 1998), 17/539; Mustafa Özkan, Dört Halife ve Emevîler Döneminde Din Devlet İlişkileri (Ankara: Araştırma Yayınları, 2015), 160-165; Osman Zahid Çifçi -Hüsamettin Erdem, "İslâm Siyaset Tarihinde Din ve Devlet İlişkisi”, ISTEM: İslâm, San'at, Tarih, Edebiyat ve Mûsikîsi Dergisi 11/22 (2013), 126.

${ }^{23}$ Mustafa Fayda, "Hulefâ-yi Râşidîn", Türkiye Diyanet Vakfi İslâm Ansiklopedisi (İstanbul: TDV Yayınları, 1998), 18/331.

${ }^{24}$ Fayda, "Hulefâ-yi Râşidîn", 324-333; Mustafa Öz - Avni İlhan, "İmâmet", Türkiye Diyanet Vakfı İslâm Ansiklopedisi (İstanbul: TDV Yayınları, 2000), 22/201-203.

${ }_{25}$ “Hz. Osman'ın şehadetiyle birlikte İslâm siyaset düşüncesinde iki farklı siyaset tarzı ortaya çıkmıştır. Birincisi, kabilelerin yerel otoritelerini ve menfaatlerini korumaya çalışan bir anlayışı benimseyen $\mathrm{Hz}$. Ömer'in siyaset tarzı, ikincisi de Kureyş aristokrasisinden meydana gelen siyaset merkezini güçlü bir şekilde devam ettirmeye çalışan bir anlayışla siyaset icra eden Hz. Osman'ın tarz-1 siyasetidir. Bu siyaset tarzlarından birincisi Hz. Ali tarafından Kufe merkezli bir devlette devam ettirilmeye çalışlırken; ikincisi de Muaviye b. Ebi Süfyan tarafından Şam merkezli bir devlette sürdürülmüştür". Ramazan Yıldırım, "Sünni Siyaset Düşüncesinin Tarih İçindeki Gelişimi ve Etkinliği", İstanbul Üniversitesi İlahiyat Fakültesi Dergisi [Darulfunun İlahiyat] 24 (2011), 11-13, 23.
} 
Hülefâ-i Râşidîn döneminde de söz konusudur ve din ve devlet işlerinde Halifeler yetkili olmuştur. ${ }^{26} \mathrm{Bu}$ noktada göz önünde bulundurulması gereken önemli bir husus, İlk Dört Halife tarafından uygulanan halifelik sisteminin, bir yandan Kur'an'ın yukarıda işaret edilen bu noktadaki temel ilkeleri ve Hz. Peygamber'in uygulamalarından hareketle oluşturulan prensiplere dayandığı mutlak olmakla birlikte diğer yandan İslâm öncesi Arap siyasi kültürünün bir takım yerleşik kabullerinin sahâbe tarafından söz konusu prensiplerle dinî bir nitelik kazandırılarak İslâmîleştirilip hayata taşındığı bir sistem hüviyetinde olmasıdır. ${ }^{27}$

Emevîler dönemi Müslümanlar arası siyasi çekişmelerin şiddetlendiği, buna bağlı olarak dinî konular hakkında farklı tartışmaların söz konusu olduğu, dinî tartışmaların aynı zamanda mevcut siyasi çekişmelere bağlı olarak da yürütüldüğü, bununla birlikte devleti idare edenlerce dinin siyasi, sosyal ve ekonomik alanlarda belirleyici olarak kabul edilmediği, hatta bir nevi "devlet için din" anlayışının hayata geçirildiği; her ne kadar idarenin "babadan oğula geçmesi" sadece Araplara ve özelde Emevîler'e ait bir özellik olmasa da yönetimin saltanata dönüştüğü, devlet yönetiminde yine Ümeyyeoğulları'nın hakimiyetinin görüldüğü ve şûraya itibar edilmediği, böylece İslâm'ın öngördüğü devlet reisliği yerine Arap asil sınıfına (Ümeyyeoğulları) dayalı bir hükümdarlık ve "mülk-devlet" merkezli bir uygulamanın getirildiği, devlet idare merkezinin Şam olması dolayısıyla coğrafya/mekan unsuruna bağlı olarak Bizans etkisinin görüldüğü ve siyasi-örfi hukukun ön planda tutulduğu bir dönem olmuştur. ${ }^{28}$

Abbâsîler döneminde halifeler, "genellikle Emevîler'in temsil ettiği 'mülkdevlet' anlayışı yerine "dine dayalı devlet" şeklinde bir halifelik fikir ve idealini temsil eden kişiler olarak karşılansalar ve buna bağlı olarak Hz. Peygamber' in hırka1 şerifini giyerek Cuma namazı kıldırıp etraflarında devlet işlerinde görüşlerine müracaat ettikleri fıkıhçılar ya da diğer din âlimlerini bulundursalar da Abbâsî halifeleri mutlak bir hükümdar; halifelik de yine verasete dayalı bir hükümdarlık şeklinde devam etmiş; bununla birlikte halifeler İlk Dört Halife'nin aksine -ki onlar 'halîfetullah' unvanının kullanılmasını reddederek yerine Hz. Peygamber' in halifesi olduklarını ifade eden unvanlar kullanmışlardır.- Emevî hükümdarlarında olduğu üzere "halîfetullah" ya da "zıllullâh fil'-arz" unvanını kullanmaktan

\footnotetext{
${ }^{26}$ Yavuzer, Çă̆gaş Din Hizmeti ve Diyanet İşleri Başkanlığı, 33-36.

${ }^{27} \mathrm{Bu}$ dönemdeki din devlet ilişkisi hakkında bir nevi "din için devlet" anlayışının söz konusu olduğuna işaret eden Özkan bu noktada şunları dile getirmektedir: "Zira şekil ve işleyiş olarak hilâfet ile İslâm öncesi Arap kabile yönetimi arasında -başkanın sıfatları ve otorite kaynağı dışında- pek bir fark yoktur. İkisinde de toplumun en yaşlı üyesi, ileri gelenler tarafından ömür boyu seçilmişlerdir. Her iki sistemde de veliahtlık anlayışı ve uygulaması yoktur. Yine hem kabile yönetiminde hem de hilafette devlet başkanı şûra kurumunun kararları doğrultusunda hareket etmiş ve aynı zamanda topluma karşı sorumlu davranmıştır." Özkan, Dört Halife ve Emevîler Döneminde Din Devlet İlişkileri, 156.

${ }^{28}$ Hakkı Dursun Yıldız, "Abbâsîler", Türkiye Diyanet Vakfi İslâm Ansiklopedisi (İstanbul: TDV Yayınları, 1988), 1/31; Özkan, Dört Halife ve Emevîler Döneminde Din Devlet İlişkileri, 159; Yıldırım, “Sünni Siyaset Düşüncesi", 11-13, 23.
} 
çekinmemişlerdir. ${ }^{29}$ Abbâsîler döneminin en belirgin özelliklerinden biri devletin idari ve siyasi teşkilatında bir kurumsallaşma faaliyetinin görülmesi ve buna bağlı olarak vezirlik, emirlik, farklı alanlarda inşa edilen divanlar, kâdı'l-kudâtlık, hisbe vb. adli ve askerî alanlarda faaliyet yürüten pek çok yeni müessesenin kurulmasıdır. Başkentin Suriye'den Irak topraklarına taşınması Abbâsîler'de İran tesirinin görülmesine yol açmış; ayrıca devletin sınırlarının genişlemesine ve yaşanan siyasiaskerî gelişmelere bağlı olarak daha önceki dönemlerden farklılık bağlamında devlet teşkilatlarında Türklerin de dâhil olduğu gayr-1 Arap unsurların varlığı söz konusu olmuştur. ${ }^{30}$

Devletlerin, hukuk sistemlerinin ya da kurumların, bir milletin ya da toplumun yaşamış olduğu coğrafya ve zamanın ruhuyla mütenasip şekillenerek aktarılan bazı tecrübelerden arındırılarak anlaşılması mümkün değildir. Bu noktada bir milletin farklı coğrafyalarda dahi dâhilî bir tekamül neticesinde aynı sistematikle (özellikle âmme hukuku alanında) kurgulamış olduğu nizamla beraber doğal ve herkes için geçerli olan bir gerçekliğe bağlı olarak bulundukları coğrafya ve zamana göre bir hal alıp bazı iktibaslarla düzenlenen nizamlarını ve kurumsal yapılarını (âmme müesseseleri/kamu kurumları) devam ettirdikleri hususunu mutlaka dikkate almak gerekmektedir. ${ }^{31}$ Nitekim bu husus, Selçuklular devri sultanlık ve halifelik uygulamalarında daha bariz bir şekilde görünürlük kazanmaktadır.

Genel idare içerisinde yer verilen Diyanet İşleri Başkanlığı da dahil olmak üzere Türkiye Cumhuriyeti'nin, idare müesseselerinin mahiyetini ve bunların köklerini anlayabilmek için doğal olarak Cumhuriyet'ten önceki devirlere, başta en yakın devlet tecrübesi olarak Osmanlı müesseseleri olmak üzere, "Osmanlı

\footnotetext{
${ }^{29}$ Yıldız, "Abbâsîler", 33-34; Casim Avc1, "Abbâsîler ve Hilâfet", Geçmişten Günümüze Hilâfet, ed. Mustafa Sabri Kü̧̈ükaşçı vd. (İstanbul, İlem Yayınları, 2019), 142.

${ }^{30}$ Yıldız, "Abbâsîler", 38-40; Casim Avcl, "Abbâsîler ve Hilâfet", 133-163. Söz gelimi Kadı'1-Kudâtlık teşkilatı ve Abbâsî yönetimindeki Türkler hakkında bkz. Yavuz Selim Göl, "Abbasîler Döneminde Kâdı'1-Kudâtl1k", Karadeniz Teknik Üniversitesi İlahiyat Fakültesi Dergisi 5/1 (2018), 12-52; Mehmet Emin Şen, "Abbâsîler Döneminde İdarî ve Malî Kadrolardaki Türkler", İSTEM: İslâm San'at, Tarih, Edebiyat ve Mûsikîsi Dergisi 7/13 (2009), 233-259.

${ }^{31}$ Bu meyanda sözgelimi Türklerin farklı coğrafyalarda on iki sağ, on iki sol olmak üzere kurguladıkları devlet memuriyet sisteminin ya da bazı culûs merasimlerinin farklı coğrafya ve zamanlardaki Türk Devletlerinde görülmesi oldukça dikkate değerdir. Ayrıca Samaniler ve Gazneliler gibi ilk Müslüman Türk Devletlerinde de farklı teşkilatlarda hem Abbasî hem Kök-Türk ve Eftalit etkilerini görmek mümkündür. Bu itibarla Türkler gerek İslâmiyet'ten önce gerek İslâmiyet'ten sonra farklı hukuk alanlarında tarihte yaşamış oldukları coğrafyalarda komşu oldukları Çinliler, Ruslar, Macarlar, Slavlar, Araplar gibi milletler ve kurdukları devletlerden çift yönlü olarak hem etkilenmişler hem de onları etkilemişlerdir. Aynı durum İslâm Tarihinde Dört Halife sonrasında kurulan ilk devletler olan Emevîler ve Abbâsîler'de de söz konusu olmuş, bunlarda söz gelimi merkezî idare ve vilayetler teşkilatı, mahalli idareler teşkilatı, askerî, adli ve mâli teşkilatlanmada olduğu üzere Mısır, Mezopotamya ve İran kültür sahasında kurulan Sasani ve Bizans devletlerinin hukuki ananelerinin açık tesiri görülmüştür. M. Fuad Köprülü, "Ortazaman Türk Hukuki Müesseseleri”, İkinci Türk Tarih Kongresi: İstanbul 20-25 Eylül 1937 Kongrenin Çalısmaları, Kongreye Sunulan Tebliğler (İstanbul: Kenan Matbaası, 1943), 387-396, 400-404, 406417.
} 
devletinden önce Türklerin önce Anadolu'da ve Anadolu'dan önce kurmuş oldukları siyasî heyetlerin, idarî müesseselerin bütününü mukayeseli bir şekilde gözden geçirmenin gerekliliği ortadadır. Bu suretle Türklerin, Türk devletlerinin umumî seyrinde, müesseselerinde, başlangıçta en eski kabile hayatlarından kalan müesseseleri görmek mümkündür. Ondan sonra tarih sırasıyla, tarihî gelişme bağlamında içinde yaşamış oldukları Uzak Şark müşterek medeniyetinin hakim olduğu kültür sahalarında olan hukukî an'anelerin, Türklerin malum eski tribal an'aneleriyle karışmasından hasıl olmuş müesseseleri görmek mümkündür. Daha sonra Türkler müslüman olduktan sonra yine o zamana kadar gelmiş olan eski idarî müesseselerinin, eski hukuk an'anelerinin, âmme hukuku an'anelerinin tesiri ile karışık olarak İslam hukukunun ve İslam tarihinin inkişafına bağlı olarak vücuda gelen sonraki safhalar görülebilir ki, -hilâfet konusunda yukarıda zikredildiği üzerebunun en mükemmel örneği Selçuklular devrinde Büyük Selçuklu İmparatorluğu'nun teşekkülü ile kendisini göstermiştir. ${ }^{32}$

Abbâsîler devrinde tarih sahnesinde etkili bir şekilde ortaya çıkan Selçuklu döneminde "halifelik ve sultanlık ayırımı" olgusu belirgin bir hal almıştır. Bu dönemde Selçuklu Sultanları ile Abbâsî Halifeleri arasındaki ilişikler, olayların karakteri açısından iki safhada ele alınmaktadır. Birinci safhaya göre, Tuğrul Bey'in Abbâsî halifesi tarafından "Dünyanın Sultanı" unvanıyla meşru sultan ilan edilmesi ve devamındaki süreçtir. Bu süreçte Selçuklu Sultanları halifelik makamına gereken hürmeti gösterip Büveyhîler tarafından zayıflatılan Halifeliğe yeniden bir itibar kazandırsalar da bütün devlet işleri sultanın uhdesine verilmiş; geçimlerini Selçuklu Sultanlarının sağladığı Abbâsî Halifeleri, sultanın ismini kendi isminden sonra hutbelerde okutmuş, sultan tarafından hazırlanan 'temliknâme' ve 'menşur'ları tasdik etmekle sınırlı bir etkiye/yetkiye sahip olmuştur. İkinci safha ise Selçuklu iktidarında baş gösteren bir takım otorite boşluğundan yararlanıp eski itibar ve iktidarlarını tekrar elde etme çabasındaki Halifeler ile Selçuklu Sultanları arasındaki mücadeleyi ifade eden bir süreçtir. Abbâsî Halifelerinin Selçuklu Sultanlarına karşı iktidarlarını tekrar elde etmek için siyasî ve askerî faaliyetlerde bulunarak giriştikleri bu gayret, Selçuklu Devleti'nin sonunu hazırlayan dahilî ihtilaflardan birisi olsa da Selçuklu Sultanları Halifeleri Hz. Peygamber'in varisleri ve Müslümanların lideri olarak görmüş ve onlara karşı saygılarını devam ettirmişlerdir. Sonuçta Selçuklu Devleti'nin İslam dünyasında kazandığı güç ve hakimiyet doğrultusunda halifelik, Tuğrul Bey zamanında belirlenen statü üzerine Selçuklu Devleti'ne tabi bir kurum olarak varlığını sürdürmüştür." 33

Memlükler zamanında Selçuklular'a benzer bir şekilde “Arap-Kureyş kökenli ve yalnızca sembolik manevî bir fonksiyonu bulunan halifenin Memlük siyasî

\footnotetext{
${ }^{32}$ M. Fuad Köprülü, “Türkiye'de Âmme İdaresinin İnkişafı", haz. Orhan F. Köprülü, Türk Kültürü 12/ 255 (1984), 435. (434-440).

${ }^{33}$ Dursun, Osmanlı Devletinde Siyaset ve Din, 85-89; Hasan Hüseyin Adalıŏlu, "Selçuklular Devri Halifelik Telakkisi", Geçmişten Günümüze Hilafet, edit. Mustafa Sabri Küçükaşçı vd. (İstanbul: İlem Yayınları, 2019), 167-198.
} 
otoritesinin gölgesi altına girdiği bir tecrübe yaşanmıştır. Osmanlılar devrinde ise maddî ve manevî otoritenin tek kişide bir araya geldiği, hilafet anlayışıyla güçlü siyasal iktidar arasında doğrudan bir ilişki kuran siyaset felsefesinin gelişerek her türlü yaptırım gücü bulunan bir sultanın aynı zamanda halife de olduğu (Halife Sultan) bir uygulamanın boy gösterdiği bir dönem yaşanmıştır." 34

Osmanlı dönemi Şeyhülislâmlık ve Şer'iyye ve Evkâf Bakanlığından Cumhuriyet dönemi Diyanet İşleri Reisliğine geçiş sürecini tahlil açısından Osmanlı'nın kuruluşundan başlayıp gelişim ve zayıflama dönemlerinde dünyada ve Osmanlı ve yakın coğrafyasındaki siyasi, askerî, iktisâdi ve sosyal gelişmelerin yanı sıra onun devlet teşkilatı ve kurumsal yapılarının serüvenini ${ }^{35}$ de dikkat almak gerektiği açıktır. Osmanlı'da devletin başında "gayr-1 mes'ul/sorgulanamaz" bir statüyle yer alan ve tek hânedana dayalı padişah/sultan-halife, bu güç ve yetkisini Dîvân-1 Hümâyun, maliye ve kul sistemi gibi kurumlar; sadrazam, yeniçeri ağası, şeyhülislâm, kazasker gibi yetkililer aracıllğıyla kullanmıştır. ${ }^{36}$

Osmanlı devletinin en önemli kurumlarından biri Şeyhülislâmlık; en önemli görevlilerinden biri ise Şeyhülislâm'dır. Şeyhülislâm kelimesi Osmanlı öncesinde ilmî alanda bir yüceltme ya da bir şeref sıfatı olarak kullanılmıştır. ${ }^{37}$ Osmanlılar'da başlangıçta ilmî/dinî bir alanda hizmetle yükümlü olan Şeyhülislâmlık/Meşîhat-1 İslâmiyye, zaman içerisinde dinî, adli ve ilmî faaliyetleri yürüten önemli bir kurumsal yapının adı, Şeyhülislâm da bu teşkilatın başında yer alan kişinin unvanı olmuştur. ${ }^{38}$ Şeyhülislâmlığın tarihî süreç içerisinde yetki ve etkisinin genişlemesi noktasında devlet idaresinin başı olan devlet başkanının (halife, sultan) kişiliği, devlet idaresindeki kabiliyeti, din, dinî konular ve dahi din-devlet ilişkilerine dair yaklaşımı kadar din işlerini deruhte etmek üzere görevlendirilen kişilerin kabiliyet ve maharetleri ile dönemin siyasi, askerî, iktisadi ve sosyal şartlarının beraberce değerlendirilmesi gerektiği açıktır.

Osmanlı döneminde ne zaman ortaya çıktığı hakkında farklı görüşler olsa da ${ }^{39}$ Fetret devrinden sonra tekrar toparlanmaya çalışlan bir zaman diliminde, bir taraftan dâhilî diğer taraftan hâricî siyasi gelişmelerin yaşandığı $1420^{\prime}$ li yılların

\footnotetext{
${ }^{34}$ Yıldırım, "Sünni Siyaset Düşüncesi", 11-22.

${ }^{35}$ Bilindiği üzere Osmanlı dönemi siyasi ve idari teşkilatlanma klasik ve modern dönem şeklinde ele alınmakta, II. Mahmud ve Tanzimat'a kadarki dönem 'klasik'; sonrası dönem ise modern olarak tasnif edilmektedir. Mehmet İpşirli “Osmanlılar: Siyâsî ve İdârî Teşkilat: Klasik Dönem”, Türkiye Diyanet Vakfı İslâm Ansiklopedisi (İstanbul: TDV Yayınları, 2007), 33/502-505; Ali Akyıldız, “Osmanlılar: Siyâsî ve İdârî Teşkilat: Modern Dönem", Türkiye Diyanet Vakfi İslâm Ansiklopedisi (İstanbul: TDV Yayınları, 2007), 33/506509 .

${ }^{36}$ İpşirli, “Osmanlılar: Siyâsî ve İdârî Teşkilat: Klasik Dönem”, 502.

37 İsmail Hakkı Uzunçarşılı, Osmanlı Devletinin İlmiye Teşkilatı (Ankara: Türk Tarih Kurumu Yayınları, 1984), 174; Ziya Kazıc1, “Osmanlılarda Şeyhülislâmlık Müessesesi”, İslâm Medeniyeti 5/2 (1981), 39-68.

${ }^{38}$ Kazıcı, "Osmanlılarda Şeyhülislâmlık Müessesesi", 40-42; Mehmet İpşirli, "Şeyhülislâm", Türkiye Diyanet Vakfı İslâm Ansiklopedisi (İstanbul: TDV Yayınları, 2010), 39/91-92.

${ }^{39}$ Ekrem Kaydu, "Osmanlı Devletinde Şeyhülislâmlık Müessesesinin Ortaya Çıkışı", Atatürk Üniversitesi İslâmî Ilimler Fakültesi Dergisi 2 (1977), 201-205.
} 
devamında 1425 'te siyasi ve idari otoritenin dışında dinî itibara sahip mütevazı bir ilmî rütbe olarak ortaya çıkan Şeyhülislâmlık, 16, 17 ve 18. yüzyıllarda yaşanan olaylar ve süreçlere bağlı olarak güçlü bir konuma gelmiş, siyasi ve idari nüfuzu artarak Sadrazamdan sonraki en yüksek mertebeye ulaşmış, sürekli gelişerek idari yetkileri, hizmet alanları ve hizmetli sayıları çoğalmış, 19. yüzyıldaki idari düzenlemelere bağlı olarak da kabinede yer almıştır. Şeyhülislâmlığın bu güçlü konumuna gelmesinde Zenbilli Ali Efendi, Kemalpaşazâde ve özellikle de Ebüssuûd Efendi gibi şahsiyetlerin büyük rol oynadıkları kabul edilmektedir. ${ }^{40}$

Başlangıçta esas görevi, şer’î meseleler hakkında fetva vermek olan Şeyhülislâm, Osmanlı' da görülen gelişmelere bağlı olarak zaman içerisinde devlette âmmeyi ilgilendiren hususlarda (dolayısıyla dinî, siyasi ve idari konularda) fetva vermek, kanunların şer'îliğini denetlemek -bazen örfi hukukun şer'î hukuka uygunluğuna dair görüşler beyan etmek-, Divan azası olmadığı dönemlerde dahi önemli hususlarda görüşlerine müracaat edilmek; zaman içerisinde yine ilmiye sınıfıyla ilgili müderris ve müftülerin tayini ve medreselerin idare ve kontrolü dâhil her türlü tasarruftan sorumlu olmak; ayrıca kadılar, kadı askerler ve postnişinlerin tayini ile ilgili işleri yürütmek, Divan'a meclis üyesi olduktan sonra buradaki karar mekanizmasında yer almak, gerektiğinde ikinci bir görev olarak nâzırlık/bakanlık yapmak, hatta sadârete vekâlet gibi dinî, ilmî, adli ve idari pek çok ve önemli görevler üstlenmiştir. ${ }^{41}$

Dünya çapında 18 ve 19. yüzyıllarda görülen gelişmeler haliyle Osmanlı'yı da etkilemiş, buna bağlı olarak Osmanlı'da Nizâm-1 Cedîd, Tanzimat ve Meşrutiyet olarak adlandırılan dönemler ve süreçlerde, yeni idari yapıların kurulması, Yeniçeri Ocağının kaldırılması, şer’̂̂ mahkemeler dışında yeni mahkemelerin kurulması, yine medrese dışında tıp, edebiyat, harbiye, mızıka vb. okulların açılması gibi başta idari, askerî, adli, ilmî yapı ve vakıflar olmak üzere pek çok alanda bir takım dönüşümler yaşanmıştır. Bu işleri deruhte etmek üzere ilgili alanlarda yeni yapılanmalara gidilmiş, bu bağlamda Meclis-i Âyan, Meclis-i Ahkâm-ı Adliye (Şûrâ-yı Devlet ve Divân-1 Ahkâm-1 Adliye), Meclis-i Dâimî-i Maârif-i Umumî, Evkaf-1 Hümâyun Nezâreti gibi organlar ihdas edilmiştir. Bu değişim ve dönüşümden Şeyhülislâmlık kurumu da nasibini almış, Şeyhülislâm'ın o güne kadarki idari, adli ve eğitim sahasındaki yetkileri alınarak ilgili birimlere (bakanlıklara) verilmiştir. Bu dönemlerde her ne kadar fetva makamını elinde bulundurup bakanlar kurulu üyesi ve şer'î mahkemelerden sorumlu olsa da özellikle Meşrutiyet döneminde Şeyhülislâmın etki ve yetkisi oldukça zayıflamış, daha önce Sadrazamla aynı konumda olan ve padişah tarafından doğrudan atanan Şeyhülislâm; artık Sadrazama

\footnotetext{
40 Uzunçarşılı, Osmanlı Devletinin İlmiye Teşkilatı, 175-178; Kazıcı, “Osmanlılarda Şeyhülislâmlık Müessesesi", 43, İpşirli, "Şeyhülislâm", 39/92.

41 Uzunçarşılı, Osmanlı Devletinin İlmiye Teşkilatı, 179-189; Kazıcı, “Osmanlılarda Şeyhülislâmlık Müessesesi", 52-54; Ramazan Boyacıoğlu, Hilafetten Diyanet İşleri Başkanlı̆̆ına Geçiş (Ankara: Ankara Üniversitesi, Sosyal Bilimler Enstitüsü, Doktora Tezi, 1992), 45-50; İpşirli, "Şeyhülislâm”, 39/94-95; Taş, “Osmanlı Yönetim Sisteminde Şeyhülislâmlık Kurumu”, 84-95.
} 
bağlı bir makam olması hasebiyle Sadrazamın padişaha teklifiyle göreve getirilir hale gelmiştir. ${ }^{42}$

Osmanlı'nın son demlerinde yaşanan gelişmelere bağlı olarak İstanbul'da Şeyhülislâmlık son dönemlerini yaşarken; Ankara'da kurulan Büyük Millet Meclisi bünyesinde Şeyhülislâmlık ile Evkaf-ı Hümâyun Nezâreti'nin görevleri birleştirilerek 1920'de Şer'iyye ve Evkaf Nezâreti kurulmuştur. ${ }^{43} 1922$ yılında bir taraftan Vahdettin ve VI. Mehmet'in İstanbul'u terk etmesi diğer taraftan yine 30 Ekim 1922 yılında Millet Meclisi tarafından Osmanlı Devleti'nin sona erdiği, onun yerini Yeni Türkiye Hükümeti'nin aldığı ilan edilip böylece saltanatın kaldırılması, halifeliğin -İslam dünyasındaki etkisine bağlı olarak 21 Kasım 1922'de Ankara Hükümeti Abdülmecid Efendi'yi onayla halifelik makamına oturtsa da- 3 Mart $1924^{\prime}$ te kaldırılmasıyla ${ }^{44}$ Şeyhülislâmlık da fiilen sona ermiştir. ${ }^{45}$

03 Mart 1924 tarihli ve 429 sayılı "Şer'iye ve Evkaf ve Erkân-ı Harbiye-i Umumiye Vekâletlerinin İlgasına Dair" Kuruluş Kanunu ile Şer'iyye ve Evkaf Vekâleti kaldırılmış, bu vekâletin yürüttüğü görevlerden şer'iyye/din işlerini 'belirlenen sınırlar' içerisinde yürütmekle yükümlü olarak Diyanet İşleri Reisliği; vakıflarla ilgili işleri deruhte etmek üzere de Evkaf Umum Müdürlügüu (Evkaf Müdürüyet-i Umumiyyesi/Vakıflar Genel Müdürlüğü) olmak üzere iki ayrı kurum kurulmuştur. 46

Osmanlı'dan Cumhuriyet'e geçiş dönemindeki süreç ve bu noktadaki genel tavra bağlı olarak ilgili Kanun'la geçmişte büyük oranda Şeyhülislâmlığın yetkisinde olan "muamelât-1 nâsa dair olan ahkâmın teşri ve infazı, Türkiye Büyük Millet Meclisi ile onun teşkil ettiği Hükûmete ait" kılınmış, Reisliğin/Başkanlığın görevleri ise "dini mübini İslâm'ın bundan maada itikadat ve ibadata dair bütün ahkâm ve mesâilinin tedviri ve müessesatı diniyenin idaresi" ile sınırlandırılmıştır. Böylece Cumhuriyet'le birlikte Başkanlığın hizmet alanının Şeyhülislâmlığın ilk kurulduğu 1420'li yıllardaki durumuna benzer bir hal ile şekillendirilmiş olduğu görülmektedir.

\footnotetext{
${ }^{42}$ Ramazan Boyacıoğlu, "Tarihi Açıdan Şeyhülislâmlık, Şer'iye ve Evkaf Vekaleti”, Cumhuriyet Üniversitesi İlahiyat Fakültesi Dergisi 1 (1996), 164-167; Mehmet Akif Aydın, "Şeyhülislâmlıktan Diyanet İşleri Başkanlığına Din Devlet İlişkileri”, Türkiye Cumhuriyeti Devletinin Temel Dinamikleri Açısından 3 Mart 1924 Yasaları ve Günümüze Yansımaları Sempozyumu Bildirileri, haz. Hale Şıvgın (Ankara: Gazi Üniversitesi Yayınları, 2007), 221-223. 221-226.

43 Boyacıoğlu, "Tarihi Açıdan Şeyhülislâmlık, Şer'iye ve Evkaf Vekaleti", 169-170; Aydın, "Şeyhülislâmlıktan Diyanet İşleri Başkanlığına Din Devlet İlişkileri", 224; Ali Akyıldız, "Şer'iyye ve Evkaf Vekâleti", Türkiye Diyanet Vakfı İslâm Ansiklopedisi (İstanbul: TDV Yayınları, 2010), 39/7.

${ }^{44}$ Halifeliğin TBMM'ce ilga sürecinde Meclis'te yürütülen işlemler ve konuşmalar hakkında bkz. Boyacıoğlu, Hilafetten Diyanet İ̧̧leri Başkanlı̆̆ına, 71-180.

${ }^{45}$ Boyacıoğlu, "Tarihi Açıdan Şeyhülislâmlık, Şer'iye ve Evkaf Vekaleti”, 167-168; Azmi Özcan, "Hilâfet: Osmanlı Dönemi", Türkiye Diyanet Vakfı İslâm Ansiklopedisi (İstanbul: TDV Yayınları, 1998), 17/550-552. Halifeliğin TBMM'ce ilga sürecinde Meclis'te yürütülen işlemler ve konuşmalar hakkında bkz. Boyacioğlu, Hilafetten Diyanet İşleri Başkanlı̆̆ına, 71-180.

${ }^{46}$ Aydın, "Şeyhülislâmlıktan Diyanet İşleri Başkanlığına Din Devlet İlişkileri", 224; Akyıldız, "Şer'iyye ve Evkaf Vekâleti", 8.
} 
Ancak Türkiye Cumhuriyeti idari sistemi içerisinde yer verilen Diyanet İşleri Başkanlığının kanunla belirlenen görev ve yetkileri ülkenin geçirmiş olduğu siyasi, iktisadi, kültürel vb. şartlar çerçevesinde şekillenerek bugünlere gelinmiştir. Nitekim 1. Numaralı başlıkta (Diyanet İşleri Başkanlığı: Kuruluş ve Temel Görevlerine Dair Kısa Tarihçe) ortaya konulan genel çerçeve bunu teyit etmektedir. Bu bağlamda 1931 yılında kabul edilen bütçe Kanunu ile cami ve mescitlerin idaresi ile imam, hatip ve hizmetlilerin atama ve sair özlük işlerinin Vakıflar Genel Müdürlüğüne devredilip bu uygulamanın 23 Mart 1950 tarihli ve 5634 sayılı Kanuna kadar devam ettirilmesi, söz konusu işlerdeki yetki ve sorumlulukların ancak bu Kanunla tekrar Diyanet İşleri Başkanlığına devredilmiş olması, ${ }^{47}$ 1926'da fiilen başlatılan ${ }^{48}$ ve herhangi bir yasal düzenleme yapılmadan ${ }^{49}$ ve Başkanlık ya da diğer başka bir birimden herhangi bir görüş de alınmadan telkin, emir ve tamimler ${ }^{50}$ ile yoğun olarak 1932'li yıllardan itibaren yürütülen ve 1933'ten sonra ülke genelinde yaygınlaştırılan ${ }^{51}$ ezanın Türkçe okunması hususunda görevlilerin eğitimi ve uygulamaların takibinin yine Vakıflar Genel Müdürlüğü tarafından yapılmasi ${ }^{52} \mathrm{vb}$. hususlar bu noktada dikkate değerdir. $\mathrm{Bu}$ husus Başkanlık hakkında yapılan çalışmaların Cumhuriyet dönemindeki gelişmelere bağlı tarihlendirilerek yürütülmesi ile de açıkça görülmektedir. Nitekim söz konusu çalışmalarda Başkanlıkla ilgili olarak 1924'ten 1950'ye, 1950'den 1965'e, 1965'den 1982'ye, 1982'den 2010'a ve 2010'dan sonrası şeklinde bir tarihlendirme yapılmaktadır. ${ }^{53}$ Buna 2018 yılında ülkede Cumhurbaşkanlığ

${ }^{47}$ Aydın, "Şeyhülislâmlıktan Diyanet İşleri Başkanlığına Din Devlet İlişkileri", 225; "Diyanet İşleri Başkanlığı", 75-76.

48 Şerif Demir, “Ezanın Türkçe Okunması (1932-1950)", Ortak Dilimiz Ezan, ed. Mahmut Öztürk (İstanbul: Nida Akademi, 2018), 86. 1926 yılında Erenköy Camisinde bir müezzinin ezanı Türkçe okuması üzerine birtakım itirazlar ve şikayetler olması üzerine Diyanet İşleri Reisliği bu müezzini geçici olarak görevden almıştır. Seçil Akgün, “Türkçe Ezan”, Tarih Araştırmaları Dergisi 13/24 (1979/1980), 108.

49 Başak Ocak Gez, "İbadet Dilinin Türkçeleştirilmesi Aşamalarından Biri: Türkçe Ezan ve Uygulamaları", Çağdaş Türkiye Tarihi Araştırmaları Dergisi 2/6-7 (1996-1997), 160. Ezanın Türkçe okunması ilgili ilk kanunî düzenlemelerin ezanın Türkçe okunmasına karşı çıkanlar için düzenlenen cezaları içeren bir düzenlemeyi muhtevi 2 Haziran 1941 tarihli ve 4055 sayılı Kanunla Türk Ceza Kanunu'nun 526. maddesinin 2. Fikrasında yapılan düzenleme olduğu görülmektedir. Gözaydın, Diyanet, 28; Demir, "Ezanın Türkçe Okunması", 91-93. Bu durum o dönemde farklı mecralarda ve şekillerde ülkede ezanın Türkçe okunmasına karşı çıkıldığını da göstermektedir. Akgün, "Türkçe Ezan", 110-111; Rıfat Atay, “Türkçe Ezan Uygulamasının Toplumsal Hafızada Yol Açtı̆ı Travmalar Üzerine”, Ortak Dilimiz Ezan, ed. Mahmut Öztürk (İstanbul: Nida Akademi, 2018), 116-139; Önder Duman- Mehmet Aydın, “27 Mayıs'ın Gölgesinde Bir "İrtica” Hamlesi: Türkçe Ezan", Uluslararası Tarih Araştırmaları Dergisi 11/6 (2019), 22692270; Sabri Zengin, “Zile'de Türkçe Ezana Tepki Olayı”, Gaziosmanpaşa Üniversitesi Sosyal Bilimler Araştırmaları Dergisi 1 (2014), 167-180.

${ }^{50}$ Atay, "Türkçe Ezan Uygulamasının Toplumsal Hafızada Yol Açtı̆̆ Travmalar", 116. Diyanet İşleri Reisliği/Başkanlığı 6.3.1933 tarihinde "ezanların Türkçe okunduğu bir zaman diliminde salât ve selâmların Arapça okunmasının bir ahenksizlik meydana getirdiği, aynı zamanda 'hükümet-i celîlenin takip buyurduğu maksada gelmediğine binaen' okunan salât ve selâmların Türkçe okunması" hususunda bir tamim yayımlamıştır. Akgün, "Türkçe Ezan”, 112.

${ }^{51}$ Duman-Aydın, "Türkçe Ezan", 2269.

${ }^{52}$ Gez, “Türkçe Ezan ve Uygulamaları", 161-163; Duman-Aydın, “Türkçe Ezan”, 2269.

53 Özaydın, Diyanet, 20-67, 311-374; Yavuzer, Çağdaş Din Hizmeti, 111-122; Ejder Okumuş, "Dindarlık ve Diyanet", Eski Yeni: Üç Aylık Düşünce Dergisi 10 (2008), 40-41; Hasan Yavuzer, “Diyanet İşleri Başkanlığ1 ve Din Hizmetleri", Din Hizmetleri ve Din Eğitiminde Türkiye Tecrübesi (Ankara: Diyanet İşleri Başkanlığ1 
geçilmesi ve Başkanlığın doğrudan Cumhurbaşkanlığı'na bağlanması ve sonrası yaşanan gelişmeleri de eklemek yerinde olacaktır. Nihayet Başkanlığın yetki ve etki olarak Cumhuriyet tarihindeki seyrinin de önceki dönemlerde olduğu üzere ülkenin yaşamış olduğu özellikle siyasi gelişmelere bağlı olarak şekil aldığı açıkça görülmektedir.

\section{Başkanlığın Yetki Alanının Belirlenmesi Hususu Bağlamında Şer'î Hukuk ve Örfî Hukuk Olgusu}

Başkanlığın Cumhuriyet döneminde görev, yetki ve etki alanının şekillenmesi hususunun tevarüs edilen kurumsal yapılar kapsamında ve din-devlet ilişkilerinin seyri çerçevesinde göz önünde bulundurulması gereken önemli bir konu ise "şer'î ve örfî hukuk ayırımı" meselesidir. Hakkında farklı kabuller ve tartışmalar bulunmakla birlikte İslâm tarihinde ortaya çıkan ictimai ve iktisadi şartlara göre şekillenen fiilî uygulamalar, -zaman ve devletlerin temel yaklaşımlarına göre derece farklılıkları olsa da-, bir yandan devletler tarafından görevlendirilen kadılarca tatbikine imkân tanınan İslam hukukuna (Kitap ve Sünneti merkeze alarak hem teşri’ kaynakları hem zaman ve mekana göre ortaya konulan içtihat mekanizması ile birbirinden farklılaşabilen; bununla birlikte dinî mahiyetini her zaman koruyan fıkha) dayalı şer'̂̂ $k a z a$; diğer yandan yine devletin yüksek otoritesinden çıan ve devletçe görevlendirilen memurlar tarafından uygulanan örfi kaza, 19. asırda Avrupa hukuku tesiri başlamadan önce de uzunca bir müddet beraberce varlığını devam ettirmiştir. Bu noktadaki tarihî tecrübenin daha çok örfî hukuk uygulamalarını daha baskın bir karakterde olduğunu gösterdiği oldukça dikkat çekicidir. ${ }^{54}$

Bu olguda başta İslâm fıkhının potansiyel ve kabiliyeti, devlet yöneticilerine tanınan selâhiyet ve bu selâhiyete bağlı olarak devlet idarecilerinin ortaya koydukları irade ve hükümranlık gibi olayın farklı bileşenlerinin birlikte ele alınması gerektiği ortadadır. Nitekim "tarih boyunca 'muhtelif İslâm memleketlerinde görülen her türlü iktisadî ve içtimaî şartları karşılayabilmek için durmadan değişmek ve gelişme göstermek imkân ve kabiliyetini gösterebilen' İslâm fıkhının âmme hukukuna dair prensiplerinin ve 'muhtelif din ve milliyette milyonlarca tebaaya hükmeden Devlet yöneticilerinin (İmparator-Sultanlar), ortaçă̆ dünyasında hükümran olan 'hukukun şahsîliği' prensibine uyarak, hususi hukuk sahasında herkesi kendi din ve milliyetine ait hukuk kaideleri ile idare edilmekte serbest bırakmakta bir mahzur bulmadıkları halde, âmme haklarına ve idare teşkilâtına ait

\footnotetext{
Yayınları, 2019), 74-79; Ahmet Koç, "Diyanet İşleri Başkanlığı ve Yaygın Din Eğitimi”, Din Hizmetleri ve Din Eğitiminde Türkiye Tecrübesi (Ankara: Diyanet İşleri Başkanlığı Yayınları, 2019), 114-126.

${ }^{54}$ Köprülü, "Ortazaman Türk Hukuki Müesseseleri”, 397-400; Dursun, Yönetim-Din İlişkileri Açısından Osmanlı Devletinde Siyaset ve Din, 104. Osmanlı'nın son dönemlerinde İslâm fikhının potansiyeli ve içtihat hakkındaki tartışmalar ile ilgili olarak bkz. Kaşif Hamdi Okur, "İslâm Hukukunda Çağdaşlaşma Arayışlarının Arka Planı: Son Dönem Osmanlı Düşüncesinden Günümüze Uzanan Süreç", İslâmî İlimler Dergisi 3/1 F1kıh Sayıs1 (2008), 155-173.
} 
hususlarda devletin hayati menfaatleri ve siyasi mülâhazalar söz konusu olduğundan, zamanın icaplarına uygun yenilikleri kabul etmek hususunda kayıtsız kalmayarak ve umumiyetle bir tevil veya tefsir yoluyla ve devlet reisi sifatiyla sultanlara bırakılmış olan takdir ve ta'zir hakları veya âmme menfaatleri prensibine dayanan kararlar gibi mevcut müsamaha ve müsaadelerden istifade ederek yeni nizamlar kurmak imkânını bulmaları"nın ${ }^{55}$ asıl etken olduğu görülmektedir.

$\mathrm{Bu}$ noktada Prof. Dr. Ali Bardakoğlu'nun şu kanaatinin burada paylaşılmasında fayda vardır: "Şer'î hukukun sınırlı bir alanı kapsadığı ve bunun da daha ziyade ibadetlerle, helal ve haramla, uhrevî sorumlulukla yakından ilgili, ahlakî değerlerin açılımı niteliğindeki hükümler olduğu; geride özellikle kamu hukuku alanında büyük bir bilinçli boşluğun bırakıldığı göz önünde bulundurulursa her toplumda 'örfî hukuk' benzeri bir gelişme kaçınılmaz görünmektedir. Ancak İslâm tarihinde ilk dönemlerin fıkıh geleneğinde böyle bir ayırıma gidilmeyip, olayların gelişim seyrine göre atılacak her yeni adımın, yapılacak her hukukî düzenlemenin şer’î hukukun genel örgüsüyle irtibatlandırılması ve onun bir parçası haline getirilmesi yolu seçilmiştir. Buna dinin genel kavram ve değerlere olan atıfları yeterince imkan verdiği gibi mevcut şartlar da böyle bir bütünlüğü gerekli kılmaktaydı."56 Bardakoğlu, "Osmanlı tatbikatında yer aldığ1 ileri sürülüp örfî hukukun şer'î hukuka aykırı olarak geliştiğinin ve devletin hukukî düzenlemeler getirirken dinî hükümlerden bağımsız bir politika izlediğinin örnekleri olarak zikredilen mirî arazi sistemi, faiz ve narh uygulaması, şer'î cezaların tatbik edilmeyişi veya başka cezalara tahvili, kardeş katli, şer'î hukukta öngörülmemiş bazı cezaların uygulanması gibi konuların önemli bir bölümünün, klasik dönem doktrin ve uygulamasına uygun düşmediği, bir diğer kısmının da Kur'an (Kitap) ve Sünnet' in konuyla ilgili ifadelerinin literal anlamına aykırı düştüğü için tereddütle karşılanıp şeriata aykırılıkla nitelendirilmesi" 57 hakkında "İslam hukukunun, tarihin belli bir

\footnotetext{
${ }_{55}$ Ömer Lutfi Barkan, "Osmanlı İmparatorluğu Teşkilat ve Müesseselerinin Şer'iliği Meselesi”, İstanbul Üniversitesi Hukuk Fakültesi Mecmuası 11/3-4 (1945), 205-206. Gerçekten, "İslâm hukukçuları da sultanları, umumiyetle şer'î hukukun (fıkıh) esas hükümlerinin sarih bir şekilde aksini emretmediği ve âmme maslahatının icap ettirdiği gibi mülâhazalarla, örf ve âdetlere uyarak veya bizzat kanun koyma yoluyla devletin esas nizam ve teşkilâtında ve idare usullerinde imam rey ve tedbiri için açık bırakılan teşebbüs sahalarında yenilikler yapmak hususunda serbest addetmekledirler. Bu suretle açık bırakılan bir takım kapıların arkasında İslâm memleketlerinde şer î hukuktan (fıkıh) ayrı bir kanun koyma kuvveti ve yolu ile bir hukuk sahası teşekkül ve inkişaf edebilmiştir." Barkan, "Osmanlı İmparatorluğu Teşkilat ve Müesseselerinin Şer'iliği Meselesi”, 205-206. Ayrıca bkz. Ali Bardakoğlu, “Osmanlı Hukukunun Şer'îliği Üzerine", Osmanll: Teşkilât (Ankara: Yeni Türkiye Yayınları, 1999), 4/415.

${ }^{56}$ Bardakoğlu, "Osmanlı Hukukunun Şer'îliği Üzerine”, 415. "Siyâset-i şer'iyye” diye de bilinen örfî hukuk uygulamalarının İslâm fikhındaki temelleri hakkında bkz. Adnan Koşum, "Osmanlı Örfi Hukukunun İslâm Hukukundaki Temelleri", Selçuk Üniversitesi İlahiyat Fakültesi Dergisi 17 (2004), 145-160. İslâm hukuku, devlet hukuku ve özellikle amme hukuku bağlamında kurumların bu noktadaki durumları hakkında bazı örnekler üzerinden yapılan bir değerlendirme için bkz. Barkan, "Osmanlı İmparatorluğu Teşkilat ve Müesseselerinin Şer'iliği Meselesi", 207-221.

57 Ömer Lütfi Barkan, "Türkiye'de Din ve Devlet İlişkilerinin Tarihsel Gelişimi”, Türk Tarih Kurumu Cumhuriyetin 50. Yıldönümü Semineri, Seminere Sunulan Bildiriler (Ankara: Türk Tarih Kurumu Yayınları, 1975), 53-97.
} 
döneminde gelişimini tamamlamış ve kemal noktasına ulaşmış bir hukuk sistemi olmayıp müslüman toplumların değişim ve gelişimine paralel olarak devamlı surette kendini yenileyen canlı bir süreci ifade ettiğini, dolayısıyla mirî arazi, narh, kanunlaştırma, hapis ve para cezası gibi yeni cezaların ihdası niteliğindeki uygulamaların Osmanlı toplumunda İslam hukukunun yeni bir açlımı olarak değer taşıdığını" ifade etmektedir. ${ }^{58}$

Kaldı ki Hz. Peygamber'in vefatından hemen sonra bile ayetler ve gelenekteki uygulamaların; problemlerin çözülmesi için dönemin şartlarına göre yorumlandığ bilinmektedir. Bu bağlamda Hz. Ebu Bekir'in had tayin edilmemesine rağmen zekât vermemeyi irtidat kapsamında değerlendirip zekat vermeyenlerle savaşması, $\mathrm{Hz}$. Ömer'in had tayin edilmiş bir suç olan hırsızlık suçunu işleyenlere kıtlık nedeniyle had uygulatmaması, ayet-i kerimedeki kayda rağmen 'müellefe-i kulûb'a zekattan pay vermemesi gibi örneklerde görüldüğü üzere, Hz. Peygamber'den hemen sonra yönetim işini devralan Halifelerin Kur'an'ın ilkelerine ve Sünnet'in özüne bağlı kalarak değişen şartlardan doğan problemlere dinin söz konusu kaynaklarından çözüm bulma çabaları mutlaka göz önünde bulundurulmalıdır. ${ }^{59}$

Şer'î ve örfî hukuk tartışmalarının daha çok Osmanlı dönemi üzerinden yürütüldüğü görülmektedir. ${ }^{60} \mathrm{Bu}$ noktada Prof. Dr. Mehmet Akif Aydın'ın konu hakkındaki şu bilgilendirmesinin paylaşılmasında fayda vardır: “Osmanlılar'da hukukun önceki İslâm ve Türk devletlerinden devralınan iki mirasla, Emevî-Abbâsî devletlerinden intikal eden İslâm hukuku ve Orta Asya Türk devletlerinden gelen devlet ve hukuk geleneğiyle şekillendiği söylenebilir. Bir yandan İslâm hukuku Osmanlı hukukunun ana yapısını oluştururken öte yandan İslâm hukukunun ayrıntılı biçimde düzenlenmemiş olduğu alanları Türk devlet geleneğini temsil eden Osmanlı padişahlarının koyduğu kurallar doldurmuştur. Belli bir süreç içinde konan bu kurallar, İslâm hukukunun klasik oluşum şeklinden farklı bir tarzda ortaya çıktığı için ayrı bir isimle anılmış, klasik İslâm hukukuna "şer'î hukuk" denirken padişahların kanunlarıyla oluşan bu hukuka "örfî hukuk" adı verilmiştir. Osmanlı resmî belgelerinde ise bu ikili yapı "şer' ve kanun" kelimeleriyle ifade edilmiştir. Buradaki örfî hukuk tabiri ilk bakışta örf ve âdet hukukunu çağrıştırmaktaysa da aslında bir kanun hukukudur. Bu hukuk kuralları konurken mahallî uygulamalardan, örf ve âdetlerden yararlanılmakla birlikte bunlara yaptırım gücünü veren örf ve âdet olmaları değil; padişahlar tarafından emredilmeleridir. Öte yandan bu kurallar konurken örf ve âdetler yanında devletin hukuk ve idare anlayışı, zamanın değişen şartları ve kamu yararı göz önüne alınmıştır. Esasen örf kelimesinin

\footnotetext{
${ }^{58}$ Bardakoğlu, "Osmanlı Hukukunun Şer'îliği Üzerine”, 416.

${ }^{59}$ Osman Çifçi- Erdem, "İslâm Siyaset Tarihinde Din ve Devlet İlişkisi", 126.

${ }^{60}$ Bardakoğlu Osmanlı'nın, "bireysel dindarlıkla toplumsal gerçeklik, dinî ilke ve amaçla hukukî biçim ve araç arasında dengeyi çok iyi sağlamış ve asırlarca sürdürmüş, dinî tecrübeyi medenîleşmenin, toplumsal bütünleşmenin ve maddî gelişmenin önemli bir muharrik gücü ve unsuru yapmayı başarmış olduğu için günümüzde ayrı bir önem taşımaya başladığı” kanaatindedir. Bardakoğlu, “Osmanlı Hukukunun Şer îliğ̆i Üzerine", 412.
} 
kökünde "yönetim" anlamı da vardır. Dolayısıyla örfî hukuk "kamu yönetiminden kaynaklanan hukuk" mânasında kullanılmıştır."61

Osmanlı hukuku hakkında “Osmanlı hukuku şer'îdir, şer'î değil dünyevîdir, lâiktir, 'kadı'nın keyfî adâletidir'." 62 şeklinde görüşler ileri sürülmüştür. Padişahların iradelerinin kayıtsız ve şartsız bir kanun haline geçmekte olduğu zamanlarda bile her yeniliğin 'şer'-i şerife uygun' kaydı ile icra edildiği Osmanlı İmparatorluğunda63 şer î hukuk "nazarî ve zahirî bir şekilde de olsa, her sahada tatbik edilir gözükmesine ve bir doktrin ve sistem olarak muhtelif hukuk sahaları arasında iktibas ve iltibasları mucip olacak şekilde vaziyete hâkim bulunmasına rağmen, Türkiye'de bilhassa idare ve teşkilât hukukiyle âmme müesseseleri sahasında millî veya örfî denilebilecek bir hukuk, eski Türk devletlerinden geçen bir idarecilik an'anesi veyahut fethedilen memleketlerde tesadüf edilen vergi teşkilât ve usullerini aynen muhafaza etmek kaidesi gibi kuvvetli iki tarihî âmilin tesiri altında gelişmek ve nev'ine has hususî şekiller meydana koymak imkânını bulabilmiş ve bu suretle teşekkül eden ve kanunlarla tanzim edilen bir siyasî hukuk veya bir Devlet hukuku da hep var olmuştur." 64

Osmanlı hukuku hakkında yapılan söz konusu tartışmaları değerlendirdiği bir yazıda Prof. Dr. Ahmet Yaman şu kanaate varmaktadır: “Osmanlı hukukunun kendine özgü bir özellik taşıdı̆̆ını söyleyebiliriz. Ne bütünüyle şer' $\hat{\imath}$, ne bütünüyle seküler, ne de bütünüyle örfî. Bir taraftan devlet ve toplum hayatında, arazi rejiminde, ceza hukukunda, malî hukukta, özel hukukun bazı ayrıntılarında hem eski Türk pagan geleneklerinin, hem de Roma hukuku ve Bizans tecrübesinin nüfuzu söz konusu iken; diğer taraftan devlete hâkim olan asıl belirleyici kimliğin İslam oluşu, egemenliğin meşrûiyetinin ilahî kaynağa dayandırılması, kamusal alan dışında genellikle şer'î çözümlemelerin hakimiyeti ve zaman zaman şekli de olsa Şeriat'ın temsilcisi olan ilmiyenin devlet teşkilatındaki saygın konumu göze çarpmaktadır. Bu da bize, şartların belirlediği ve bazen zorladığı, sessiz uzlaşıların ürünü olan, dikkate değer ve kendine özgü bir hukuk düzeninin varlığını

\footnotetext{
${ }^{61}$ Mehmet Akif Aydın, “Osmanlılar: Hukukî-Adlî Yapı”, Türkiye Diyanet Vakfı İslâm Ansiklopedisi (İstanbul: TDV Yayınlar1, 2007), 33/515.

${ }^{62}$ Ahmet Yaman, “Osmanlı Pozitif Hukukunun Şer’̂̂liği Tartışmalarına Eleştirel Bir Katkı”, İslâmiyat 8/1 (2005), 114-124.

${ }^{63}$ Barkan, “Osmanlı İmparatorluğu Teşkilat ve Müesseselerinin Şer'iliği Meselesi”, 212. Bu noktada en dikkat çeken şahıs Şeyhülislâm Ebussuûd Efendi'dir. Ahmet Akgündüz, "Ebussuûd Efendi”, Türkiye Diyanet Vakfi İslâm Ansiklopedisi (İstanbul: TDV Yayınları, 1994), 10/367. Söz gelimi Barkan Ebussuud Efendi'nin mirî arazi uygulamalarını fıkha uydurmasını, âdetler veya idari tedbirlerle öteden beri zaten mevcut olan bir nizamı, şer̂̂̂ formül ve tariflerle meşru göstermek için yapmış olduğu bir tefsir ve izah (Barkan, “Osmanlı İmparatorluğu Teşkilat ve Müesseselerinin Şer'iliği Meselesi”, 223.); dönemin kadıları daha çok medresede eğitim gördüğü için, örfî hukuk çerçevesinde verilen fermanlarla kurulan sistemin kadılar tarafından zahmet çekilmeden anlaşılması adına onların dilinden olguyu izah etme olarak görmektedir. Barkan, “Türkiye'de Din ve Devlet İlişkilerinin Tarihsel Gelişimi”, 59.

${ }^{64}$ Barkan, “Osmanlı İmparatorluğu Teşkilat ve Müesseselerinin Şer'iliği Meselesi”, 207-209; Halil İnalcık,

"Kanunnâme", Türkiye Diyanet Vakfi İslâm Ansiklopedisi (İstanbul: TDV Yayınları, 2001), 24/333-335.
} 
göstermektedir." ${ }^{65}$ Sonuçta Başkanlığın Cumhuriyet'le beraber görev ve yetkilerinin dinî alanla sınırlandırılmasında söz konusu bu olgu ve hakkındaki tartışmaların etkili olduğu görülmektedir. ${ }^{66}$

\section{Tevarüs Edilen Dinî Anlayış ve İlmî Gelenek}

İslâm dünyasında Hz. Peygamber'in vefatından sonra hicrî ilk yüzyılın birinci çeyreğinden itibaren ortaya çıkıp devam eden siyasi, iktisadi, sosyal, kültürel olaylar çerçevesinde tartışılmaya başlanan "hilâfet, büyük günah, iman-amel ilişkisi, kader ve Allah'ın sıfatlarından" oluşan ana konular etrafında cereyan eden tartışmalara bağlı olarak siyasi, itikadi ve fikhi alanlarda değişik anlayışlar, mezhepler ve ekoller ortaya çıkmaya başlamıştır. Hicrî ikinci ve üçüncü asırlarda söz konusu ana konular ile beraber bunlara bağlı alt ve detay konular (söz gelimi büyük günaha bağlı olarak şefaat; sıfatlara bağlı olarak ru'yetullah/Allah'ın görülmesi ya da halku'l-Kur'an (Kur'an'ın yaratılıp yaratılmadığı) hakkında yürütülen tartışmalarla mezhep ve ekollerin oluşum süreçleri sürmüş, üçüncü asrın sonlarıyla dördüncü asırda ise bunlar çoğunlukla oluşum sürecini tamamlamıştır. Bu bağlamda Hâricî anlayışa mensup pek çok grup ve alt grup ortaya çıkmış, Ehl-i Sünnet ana anlayışında Hanefîlik, Mâlikîlik, Şâfiîlik, Hanbelîlik, Evzaîlik gibi fıkhi; Selefîlik, Eş‘arîlik ve Mâturîdîlik gibi itikadi; Şı̊a anlayışı içinde de Zeydîlik, İsmâîlîlik, İmâmiyye gibi itikadi, yine Zeydîlik ve Caferîlik gibi fikhi mezhepler tarih sahnesinde yerlerini almıştır. İlk dönemlerden itibaren ortaya çıkan söz konusu anlayışlar, mezhepler ve ekoller, yaklaşım, zihniyet, epistemolojik kabuller vb. farklı alanlardaki tavırlarına göre birtakım tasniflere tabi tutulmuştur. En başta akıl-nakil ilişkisi bağlamında Ehli Rey ve Ehl-i Hadis olarak iki ana çerçevede taksim edilen ${ }^{67}$ söz konusu anlayış, mezhep ve ekoller, epistemolojik kabulleri açısından da beyan, burhan ve irfan gelenekleri gibi bir tasnifle anlaşılmaya çalışılmıştır. ${ }^{68}$

Bu bağlamda yapılan ve bunları zihniyet açısından değerlendirip tasnif eden bir çalışma oldukça dikkat çekicidir. Buna göre İslâm tarihinde ortaya çıkan siyasi, itikadi, fıkhi-amelî, tasavvufi ve felsefi mezhep ve düşünce ekolleri tepkisel-kabilevi, akılcı-hadari, gelenekçi-muhafakâr ve politik-karizmatik liderci din anlayışları olarak tasnif edilmektedir. Katı, sert ve şiddet yanlısı olan ve nassları zâhirî ve literal

\footnotetext{
65 Yaman, “Osmanlı Pozitif Hukukunun Şer^̂̂liği Tartışmaları”, 125. Bu tür iddiaların ihtiyatla karşılanması gerektiği hakkında benzer bir değerlendirme için bkz. Aydın, "Osmanlılar: Hukukî-Adlî Yap1", 516-517.

${ }^{66}$ Erşahin, "Bir Cumhuriyet Kurumu Olarak Diyanet İşleri Başkanlığı”, 26-34.

67 Sönmez Kutlu, İslam Düşüncesinde İlk Gelenekçiler Hadis Taraftarlarının İman Anlayışı Bağlamında Bir Zihniyet Analizi (Ankara: Kitâbiyât, 2000), 39-72; Muhyeddin İ̆gde, "Selefiliğin Tarihi Arka Planı",eMakâlât Mezhep Araştırmaları 8/2 ( 2015), 151-152.

${ }^{6}$ Süleyman Uludağ, İslâm Düşüncesinin Yapısı, Selef, Kelâm, Tasavvuf, Felsefe (İstanbul: Dergâh Yayınları, 1979), 7; Muhammed Âbid el-Câbirî, Arap-İslâm Kültürünün Akıl Yapısı, Arap-İslâm Kültüründeki Bilgi Sistemlerinin Eleştirel Bir Analizi, çev. Burhan Köroğlu, Hasan Hacak, Ekrem Demirli (İstanbul: Kitabevi 1999).
} 
okuyan, dışlayıcı ve tekfir edicilik ve kabile asabiyeti vb. özellikleri ön plana çıkan tepkisel-kabilevi anlayışın din söylemi için Hâricîler örnek olarak verilebilir. Akılc1hadari anlayış ise, genel olarak Mürcie, Hanefîlik ve Maturîdiliğin de içinde bulunduğu Rey taraftarlarının genel hatlarıyla çoğulcu, sistematik düşünce ve akılcılığa dayanan, te'vîl, sorgulama ve eleştirme ve farklı görüşlere tahammül vb. özellikleri olan din anlayışını ifade etmektedir. Temsilciliğini başta Ehl-i Hadis ve Selefiyye'nin yaptığı, bu itibarla -başlangıçta Mâlikîlik ve Şâfiîliğin de içinde bulunduğu, ancak bu iki mezhebin daha sonraları bir değişime uğraması nedeniyleHanbelîlik gibi mezheplerin sürdürdügü gelenekçi-muhafazakâr anlayış ise selef/ilk üç neslin yüceltilmesi, sünnet/asâr (rivayet) merkezli bir din anlayışı, rey/akıl, kelam ve felsefe karşıtlığı, zâhirî ve literal okuma, mutlak doğruluk vb. özellikleri ile ön plana çıkmaktadır. Daha çok Şiî ve bâtıni mezheplerin benimsediği politikkarizmatik liderci din anlayışında ise siyasal iktidarın ilahîliği ve naslar tarafından belirlendiği, zamanın imamına beyat, imamların günahsızlı̆̆ı, imamlara mutlak itaat, bâtıni yorumları savunmak gibi temel özellikler bulunmaktadır. ${ }^{69}$

Farklı dinî anlayışlar ya da dinî anlayışlardaki farklılık olgusunun ete kemiğe bürünmüş hali olan mezhep ya da ekollerin ortaya çıkmasında insan, sosyal çevre, mekân/coğrafya, zaman, fikir- hadise irtibatı vb. ana unsurların yanı sıra zamanda ve mekânda ortaya çıkan siyasi, ekonomik, sosyal, kültürel her türlü olayın ve dil, toplumsal yapılar ve zihniyet kodları ile birlikte var olan her türlü "yerleşik kabul"ün ${ }^{70}$ doğal olarak etkili olduğu bilinmektedir. Bu itibarla mezhep mensubiyeti ile coğrafya ve milliyet arasında kaçınılmaz bir ilişki söz konusudur. Nitekim İslâm dünyasında mezheplerin ana hatlarla coğrafi dağılımına bakıldığında bu ilişki açıkça görülmektedir. ${ }^{71}$

\footnotetext{
${ }^{69}$ Sönmez Kutlu, Mezhepler Tarihine Giriş (İstanbul: Dem Yayınları, 2008), 55-64.

${ }^{70}$ Yerleşik kabul ile kastettiğimiz şey, bir coğrafyada/mekânda yerleşik olan dil, zihniyet kalıpları, varlık algısı, toplumsal yapılar, örf ve âdetler vb. bütünüyle dinî sosyo-kültürel hayatı şekillendiren unsurlardır. Söz gelimi İslâm tarihinin erken dönemlerinde cereyan eden bir takım siyasi ve sosyo-kültürel olayları anlamak için o zaman diliminde merkez Arabistan coğrafyasında yerleşik birtakım kabulleri dikkate almak gerekir. Bu bağlamda örnek olarak başta kabile ve kabilecilik olgusu zikredilebilir. Nitekim kabile ve kabilecilik olgusu Haricî grupların davranışlarının anlaşılmasında göz önünde bulundurulması gereken temel etkenler için güzel bir örnek teşkil ederken; aynı zamanda müşriklerin Hz. Peygamber'i öldürmek için yürüttükleri faaliyetlerde görüldüğü üzere suça/işe bütün kabilelerin temsilcilerinin dâhil edilmesi olayı da -ki aynı durum Hz. Osman'ın şehâdetiyle sonuçlanan olaylarda da görülmektedir- bu kapsamda dile getirebilecek bir misaldir. Ayrıca Kureyş' in yönetimine alışık olma ya da bu konu hakkında bir kabulün olması, yönetim işinin babadan oğula geçmesi -Cemel'de Hz. Aişe, Talha ve Zübeyr ile beraber hareket eden Hz. Osman'ın Basra Valisi'nin Hz. Osman'ın yerine oğlunun geçmesi gerektiğini ileri sürmesi ya da bu işin ete kemiğe bürünmüş hali olarak yönetimin Muâviye b. Ebî Süfyân'dan oğlu Yezid'e geçmesi bu noktada olayı anlaşılır kılmaktadır.-, Hacerü'l-Esved'in yerine konulması ya da Sıffîn'deki Tahkîm olayı örneklerinde görülen Hakemlik müessesesi, İslâm'ın düzeltmeye çalıştı̆̆ı kadın algısı vb. unsurlar bu meyanda zikredilebilecek birkaç husustur.

${ }^{71}$ Mehmet Ali Büyükkara, "İslâm Kaynaklı Mezheplerin Ortadoğu'daki Coğrafi Dağılımı ve Tahmini Nüfusları", e-Makâlât Mezhep Araştırmaları 6/2 (2013), 321-354; Adem Arıkan, "İslâm Dünyasının Mezhep Haritası ve Nüfus Dağılımı" İslâmi Araştırmalar 29/2 (2018), 348-379.
} 
Türklerin İslâmlaştıkları dönemde yaşadıkları Asya ve zaman içerisinde göçlerle yerleştikleri Anadolu ve civarı bölgelerde -her ne kadar zaman zaman Eş‘arîlik'le alakalı gelişmeler ve bir etki söz konusu olsa da-72 daha çok HanefîMâturîdî kültür havzası içerisinde oldukları bilinmektedir. ${ }^{73} \mathrm{Bu}$ gerçekliğin Türklerin kurdukları devletlerdeki kurumsal yapılara da haliyle etki edeceği, ilmî ve adli hayatın da daha çok Hanefî-Mâturîdî anlayış üzerine şekilleneceği doğal bir sonuç olarak ortaya çıkacaktır. Bu konuda devletlerin yaşadıkları zaman diliminde karşılaştıkları dâhilî ve hâricî etkiler ve şartlara göre değişik tezahürler görülmesi mutlaktır. Bizim ele aldığımız konu açısından Cumhuriyet tecrübesine en yakın dönem Osmanlı devri olduğu için bu noktada Osmanlı'daki duruma bakmak yerinde olacaktır.

Zaman zaman aksi tasarruflar söz konusu olmakla birlikte diğer mezhep mensuplarının yaşadığı -Arap- ülkelerinde Hanefîlik haricindeki Sünnî mezheplerden kadı tayin edilmesi ihmal edilmemişse de, Osmanlı'da Anadolu ve Rumeli'deki kadılar Hanefî mezhebinden seçilmiş ve bu bölgelerde fiilen Hanefî mezhebi içtihatları hâkim olmuştur. Dinî-sosyal hayatın daha çok mezhebî kabullere göre şekillenmesi olgusu bağlamında bunun bu coğrafyada yaşayan halkların büyük oranda Hanefî mezhebine mensup olmasının tabiî bir sonucu olduğu açıktır. Ancak burada göz ardı edilmemesi gereken önemli bir husus Osmanlı tecrübesinde -ender de olsa- bir hukuki sorunun çözümünde ihtiyaç duyulduğunda diğer mezheplerden nâib tayin edilerek diğer mezheplerin sağladığı kolaylıklardan faydalanma yoluna gidilmiş olmasıdır. ${ }^{74}$ Ayrıca Osmanlı' da kanun önünde eşitliğin, hukukun tatbikinde birlik ve düzenin sağlanabilmesi amacıyla yargılamada ve fetvalarda Hanefî mezhebinin esas alınma ilkesinin resmî politika olarak benimsendiği ve Ebussuûd Efendi'nin en güçlü olduğu dönemlerde, sosyal şart ve ihtiyaçlar değiştiğinde bunların göz önünde bulundurularak aile hukuku, evlilik, kahve içme, Karagöz oyunu seyretme vb. farklı konularda mezhepte yerleşik görüşlerden vazgeçilip sistem içinde farklı çözüm arayışlarına gidilmesi ${ }^{75}$ de dikkati câliptir.

\footnotetext{
72 Mehmet Kalayc1, “Eşarilik”, İslam Mezhepleri Tarihi, ed. Hasan Onat-Sönmez Kutlu (Ankara: Grafiker Yayınları, 2013), 400-401, 416-419.

${ }^{73}$ M. Saffet Sarıkaya, Anadolu Alevîliğinin Tarihî Arka Planı (XI-XIII. Yüzyıl) (İstanbul: Ötüken Yayınları, 2003), 180; Sönmez Kutlu, “Bilinen ve Bilinmeyen Yönleriyle İmam Mâturîdî”, İmam Mâturîdî ve Maturidilik (Ankara: Kitâbiyât, 2003), 17-25; Ahmet Ak, “Büyük Selçuklular Döneminde Mâturîdî Temsilciler”, II. Uluslararası Selçuklu Kültür ve Medeniyeti Sempozyumu Selçuklularda Bilim ve Düşünce (Konya: Selçuklu Belediyesi Yayınları, 2013), 2/299-318; Mehmet Kalaycı, “Mâtürîdî-Hanefî Aidiyetin Osmanlı'daki İzdüşümleri", Cumhuriyet İlahiyat Dergisi 20/2 (2016), 9-72.

${ }^{74}$ Aydın, "Osmanlılar: Hukukî-Adlî Yapı", 518; Ali Bardakoğlu, "Hanefî Mezhebi”, Türkiye Diyanet Vakfı İslâm Ansiklopedisi (İstanbul: TDV Yayınları, 1997), 16/6-7. Nitekim "Şeyhülislâmların en temel görevi kendilerine sorulan dinî, siyasî ve idarî konularda fıkha ve özellikle Hanefî fıkhına göre fetva vermektir." İpşirli, "Şeyhülislâm", 39/94.

${ }^{75}$ Akgündüz, "Ebussuûd Efendi", 10/367-368.
} 


\subsection{Başkanlığın Tek Mezhep Üzerinde Hizmet Yürüttüğü İddiası}

Başkanlık hakkında yürütülen tartışmalardan birinin Başkanlığın tek mezhep (Hanefîlik) üzerinden hizmet yürüttüğ̈̈ ile ilgili iddialardan oluştuğu görülmektedir. ${ }^{76}$ Halbuki Başkanlığın yayınları, Din Şûrâları Kararları ve Özel Raporlarını inceleyerek mezhebî tutumu hakkında çalışma yapan Mezhepler Tarihi alanında uzman Prof. Dr. M. Saffet Sarıkaya'nın yerinde tespitlerinin ortaya koyduğu üzere Başkanlığın bir mezhebî kimliğinden söz etmek mümkün görünmemektedir. Zira Başkanlık, mevzuatında da yer verildiği üzere toplumu bir nevi mezhepler üstü bir anlayışla İslâm üst kimliğinde Kitap ve Sünnet esaslı bir aydınlatmayı temel bir hizmet ilkesi olarak benimseyip bunu işletmeye çalışan bir kurumdur. 1960'lı yıllarda Başkanlık'ta bir "Mezhepler Müdürlüğü" kurulması hususuna çok sıcak bakılmaması bu durumun kamuoyunca da benimsendiğini ortaya koymaktadır. ${ }^{77}$

Tek mezhep üzerinden hizmet yürütüldügü hakkındaki söz konusu iddiaların sağlıklı bir şekilde değerlendirilmesi için öncelikle Başkanlığın vatandaşlık esaslı bir hizmetle mükellef tutulup bu meyanda hizmetlerini yürüttüğü göz önünde bulundurulmalıdır. Nitekim Başkanlık gerek yürüttüğ̈̈ hizmetlerde gerek personel istihdamında vatandaşların mezhebî ve meşrebî mensubiyetini dikkate almamaktadır.

Ancak bu noktada daha önce de işaret edildiği üzere gerek dinî düşüncenin gerek dinî hayatın İslâm coğrafyasında asırlardan beri mezhebî ve meşrebî mensubiyetler üzerinden şekillendiği ve bu olgunun son derece tabiî olduğu unutulmamalıdır. Bu durumda ülkede yaşayan vatandaşların \%80'ler gibi bir oranla kahir ekseriyetinin Hanefî mezhebine mensup olmasının, ${ }^{78}$ ülkedeki dinî düşünce ve hayatın şekillenmesinde etkili olacağı aşikârdır. Kurumların da ana karakter olarak bu meyanda şekilleneceği muhakkaktır. Dinî düşünce ve hayatın, dil, toplumsal yapılar ve zihniyet olguları bağlamında mezhebî ve meşrebî sistematiklerle şekillendiği dikkate alındığında; Hanefî ve Şâfiîlerin çoğunlukta olduğu bir toplumsal yapıda bu mezheplerin sistematiğinin işleyeceği, söz gelimi Mâlikî, Hanbelî ya da Zeydî veya İbâdî bir sistematiğin söz konusu olmayacağı açıktır.

Bununla birlikte Başkanlığın vatandaşlık esaslı hizmet anlayışı ve özellikle Başkanlığın dinî alanda ${ }^{79}$ en yüksek karar ve danışma organı olan Din İşleri Yüksek

\footnotetext{
${ }^{6}$ Taş, Türk Halkının Gözüyle Diyanet, 198-200; Ruşen Çakır- İrfan Bozan, Sivil, Şeffaf ve Demokratik Bir Diyanet Işsleri Mümkün mü? (İstanbul: Tesev Yayınları, 2005), 114-117; Gözaydın, Diyanet, 176, $246-247$.

${ }^{77}$ Mehmet Saffet Sarıkaya, "Diyanet İşleri Başkanlığı Yayınlarında Mezhebî Tutum ve Eğilimler", İslâmi Araştırmalar 29/2 (2018), 268-287.

78 Türkiye'de Dini Hayat Araştırması, haz. Diyanet İşleri Başkanlığı (Ankara: Türkiye Diyanet Vakfı Yayınları, 2014), 29.

${ }^{79}$ Bu kayıt 2010 yılında çıkartılan söz konusu Kanunla getirilmiştir. Bundan önceki Kanun metinlerinde Din İşleri Yüksek Kurulunun “dinî konularda” kaydı olmaksızın Başkanlığın en yüksek karar ve danışma organı olduğu hükmüne yer verilmiştir. Halil Altuntaş, Diyanet İşleri Başkanlı̆̆ı Din İşleri Yüksek Kurulu (Tarihçe, Oluşum, İşleyiş ve Faaliyetler) (Ankara: Diyanet İşleri Başkanlığı Yayınları, 2020), 69.
} 
Kurulunun işleyişi ve karar, mütalaa, fetva ve görüşlerinde ${ }^{80}$ uyguladığı metodik yaklaşım, söz konusu iddialar hakkında daha ihtiyatlı olunması gerektiğini ortaya koymaktadır. Zira -ileride daha detay bilgi sunulacağı üzere- yukarıda ifade edilen gerçekliğe bağlı olarak çoğunlukla Hanefî görüşler üzerinden faaliyetlerini yürüten Din İşleri Yüksek Kurulu Başkanlığı karar, mütalaa, fetva ve görüşlerinde, “Hanefî mezhebinin klasik bir konudaki görüşünün; uygulamanın soru soran kişi için ciddî zorluklar doğurması, bir görüşün yeni bilimsel gelişmelere göre tashih edilmesi gerektiğinin anlaşılması, görüşün çok zayıf olması, geçmişte yaşanmış ancak bugün itibariyle yaşamayan örflere göre verilmiş olması, toplumsal ihtiyaçları ve sorunları gidermede yetersiz kalması, hacdaki şartlarda görüldüğü üzere bir zaruret durumunun ortaya çıkması, günümüzün değişen şartlarının -seyahat araçları gibieski belirlemeleri manasız ve imkansız hale getirmesi gibi hallerde hangi mezhebin görüşü ve sistematiği uygunsa ona göre bir tercihte bulunarak bir işlem ve bilgilendirme yapmaktadır. Kurul günümüz şartlarında ortaya çıkan sigorta, estetik ameliyatı, organ nakli, tüp bebek uygulaması gibi yeni konularda ise Kitap ve Sünnet'in ma'kul, maksûd ve mefhûmundan hareket edip fikhın genel/küllî kuralları/kavâidi ile kendi karar, mütalaa, fetva ve görüşlerini oluşturmaktadır." ${ }^{81}$

Ayrıca bir görüşe esas olan gerekçe ya da konu hakkındaki malumat değişmişse bu durumda hangi mezhebin görüşü ve sistematiği uygunsa ona göre bir tercihte bulunarak bir işlem yürüten Kurul, kendisine mektup, mail, faks vb. farklı yollarla yöneltilen sorulara eğer soru içinde mezhebî bir talep varsa onu dikkate

\footnotetext{
${ }^{80}$ Burada "Din İşleri Yüksek Kurulunun karar, mütalaa, fetva ve görüşleri” kullanımı hakkında bilgi vermek yerinde olacaktır: Karar, bir konu hakkında Din İşleri Yüksek Kurulu üyelerinin ittifakla ya da salt çoğunlukla almış olduğu kararları; mütalaa, Kurulun üye sayısı salt çoğunluğu sağlamadığı zamanlarda -söz gelimi 1971-78 arasında seçim yapılamadığ1 için tam kadro Kurul kurulamamış, 86 yılında da üye sayısı 3'e indiği için karar alamamıştır. Bkz. Altuntaş, Din İşleri Yükssek Kurulu, 98-101, 107Başkanı ya da Vekili'nin imzasıyla paylaşılan görüşleri; fetva, vatandaşlar tarafından mektup, faks, elektronik posta vb. farklı yollarla Kurula yöneltilen sorulara Kurulun -kimi zaman Komisyonlar marifetiyle ama çoğu zaman uzman görüşü olarak uzmanlar tarafından- verdiği dinî bilgilendirme mahiyetindeki cevapları, görüş ise Kurulaa gerek Başkanlık Makamı ve merkez birimleri gerek il ve ilçe teşkilatları gerekse Kurum dışından farklı kurum ve kuruluşlar tarafından farklı konularda yöneltilen soru, talep vb. hususlara verdiği cevapları ifade etmektedir.

81 Ahmet Yaman, "T.C. Diyanet İşleri Başkanlığı Din İşleri Yüksek Kurulunun Fetva Yöntemi”, Din Hizmetleri ve Din Eğitiminde Türkiye Tecrübesi (Ankara: Diyanet İşleri Başkanlığı Yayınları, 2019), 47-70. İlgili makalenin Arapçası için bkz. Ahmet Yaman, "Riâsetü'ş-Şuûni'd-Dîniyye fî Türkiyâ Turuku ve Esâlîbu Isdâri'l-Fetâvâ min Kıbeli'l-Meclisi'l-E'lâ li'ş-Şuûni'd-Dîniyye”, Mecelletü'd-Diyâneti'l-'İlmiyye bi'lLü̈̆ati'l-'Arabiyye/Diyanet Arapça İlmi Dergi 1 (2019), 61-95. Yukarıda zikredilen hususlardan söz gelimi yeni bilimsel veriler ortaya çıkması durumunda Kurulun karar veya görüşünü değiştirdiğine dair bir örnek vermek yerinde olacaktır. Nitekim tüp bebek konusunda teknolojik gelişmeler neticesinde tüplerde döllendirilecek sperm ve yumurta hücrelerinin en uygun olanının tespit edilip döllendirilmesi imkânı doğunca, Kurul hayatın başlangıcı ve yaşama hakkının yumurta ve sperm hücrelerinin döllenmesiyle başladığ1 kabulünden hareketle çoklu döllenme hakkındaki görüşünü değiştirmiştir. https://kurul.diyanet.gov.tr/Cevap-Ara/38223/tup-bebek-yonteminde-rahme-yerlestirilmeyen-fazlaembriyolarin-yok-edilmesi-caiz-midir-? (Erişim tarihi: 03.10.2021). Diğer mezheplerin görüşleri esas alınarak verilen karar, mütalaa ve fetvalar için bkz. Mustafa Bülent Dadaş, "Kuruluşundan Günümüze Din İşleri Yüksek Kurulunun Fetva Siyaseti", Türkiye Araştırmaları Literatür Dergisi 13/25-26 (2015), 53-58.
} 
alarak; yoksa da konu hakkında mezheplerin farkı görüşleri söz konusu ise bazen ülkedeki mezheplerin görüşlerine beraberce yer vererek bir bilgilendirme yapmaktadir. ${ }^{82}$

Bu bağlamda Din İşleri Yüksek Kurulu Başkanlarından Prof. Dr. Şamil Dağcı'nın Din İşleri Yüksek Kurulu Kararları hakkında yaptığı bir çalışmada dile getirdiği şu hususu aynen paylaşmak yerinde olacaktır:

“Sorulara cevap hazırlamada Kur'an ve Sahih Sünnet, temel kaynak ve dayanak konumundadır. Kurulumuz, Kur'an ve Sünnet'i anlama ve yorumlamada lafız-anlam bütünlüğünü temel ilke kabul etmekte, yanlış anlaşılmalara ve huzursuzluklara sebebiyet verebilecek üsluptan kaçınmaya itina göstermektedir.

Kurul; mezhepleri, Kur'an ve Sünnet'in anlaşılıp yorumlanmasında tarihsel süreçte ortaya çıkan görüş farklılıkları; bu görüş farklılıklarını da alternatif çözüm önerileri olarak telakkî etmektedir. Başka bir ifade ile herhangi bir dinî konuya ilişkin farklı görüşler Kurulumuzca, o konuya dair alternatifler (ve tabiî olarak da zenginlik) olarak algılanmakta ve bu tarihî-kültürel birikim çok önemli bir malzeme oluşturmaktadır. Kurul, hazırladığı cevaplarda bu alternatif çözüm önerilerinden olabildiğince yararlanmaktadır. Bununla beraber Kurulun kararları, belli bir mezhebin değil; Din İşleri Yüksek Kurulunun görüşlerini yansıtmaktadır." ${ }^{83} \mathrm{Bu}$ durumda Başkanlık hakkında tek mezhep üzerinden hizmet yürüttüğü ile ilgili iddialar gerçeği yansıtmamaktadır ve ihtiyatla karşılanmalıdır. Kanunun Din İşleri Yüksek Kurulunun görevleri ile ilgili olarak birinci sırada yer verdiği "İslam dininin temel bilgi kaynaklarını ve metodolojisini, tarihî tecrübesini ve güncel talep ve ihtiyaçları dikkate alarak dinî konularda karar vermek, görüş bildirmek ve dinî soruları cevaplandırmak." ${ }^{84}$ hükmü de bunu açıkça teyit etmektedir.

\subsection{Diyanet İşleri Başkanlığının Tek Mezhep Merkezli Hizmet Yürüttüğü İddiası ve Alevî Gelenek Mensubu Ocak ve Grupların Bu Tartışmaya Dâhil Edilmesi}

Diyanet İşleri Başkanlığının tek mezhep çerçevesinde hizmet verdiği hakkındaki tartışmaların Alevî geleneğin de işin içerisine katılarak yürütüldüğü dikkat çekmektedir. Başkanlık ve Alevî gelenek mensubu ocak ve gruplarla ${ }^{85}$ ilgili olarak yapılan tartışmalar, Başkanlığın kaldırılmasından yeniden yapılandırılmasına, Alevîliğin Başkanlık'ta temsil edilmesinden Başkanlığın Alevî

\footnotetext{
${ }^{82}$ Dadaş, “Din İşleri Yüksek Kurulunun Fetva Siyaseti”, 42-58.

83 Şamil Dağc1, “Din İşleri Yüksek Kurulu Kararlarına Fetva Konseptinde Bir Yaklaşım”, Diyanet İlmi Dergi 38/4 (2002), 11.

${ }^{84}$ Diyanet İşleri Başkanlığı Kuruluş ve Görevleri Hakkında Kanun (DİB Kanun), Resmî Gazete 12038 (2 Temmuz 1965), Kanun No: 633, m. 5.

85 Ocaklar, geleneksel ocak yapılanmasını; gruplar ise şehirleşme ile ortaya çıkan Cem Vakfı, Pir Sultan Abdal Dernekleri vb. örgütlülük gerçeğinde ortaya çıkan yeni yapılanmayı ifade etmektedir. Cenksu Üçer, Anadolu'da Alevî Ocakları ve Grupları (Ankara: Ankara Okulu Yayınları, 2020), 418-434.
} 
gelenek mensuplarının ihtiyaçlarının karşılanması hususuna biraz daha fazla ilgi göstermesine varıncaya kadar farklı alanlarda yürütülmektedir. ${ }^{86}$ Bilindiği üzere özellikle 1990'lı yıllarda dünyada ve ülkede görülen bir takım gelişmeler bağlamında kimlik politikası olgusu yaşanmış ve bu çerçevede bir Alevî kimliği inşası söz konusu olmuştur. Ayrı bir inanç olduğu iddiaları da dâhil değişik alanlarda yürütülen bu inşa sürecinin, mezhebî ve meşrebî oluşumlar bağlamında yürütülen kısmında Alevî geleneğin bir mezhep olduğu algısı ve "Sünnîlik" karşısında konumlandırıldığı görülmektedir. Konu hakkında bu bağlamda yürütülen tartışmaların da başta Mezhepler Tarihi olmak üzere İlahiyat disiplinlerinin bilimsel veri ve kriterlerine göre sağlıklı olmadığı ve dolayısıyla mecrası dışında yürütüldüğü dikkat çekmektedir.

$\mathrm{Bu}$ çerçevede yürütülen tartı̧malar birkaç açıdan değerlendirilebilir. Öncelikle Alevî gelenek bir mezhep değil; tasavvuf düşüncesi ve hayatının söz konusu olduğu bir yapıdır. İkincisi Sünnîlik de bir mezhep değildir. Yukarıda işaret edildiği üzere içinde itikâdi ve fıkhi mezhepleri barındıran bir çerçeve anlayıştır. Bir diğer husus Alevîlik ile Sünnîlik mukayese edilebilir türdeşler değildir. Bilindiği üzere Sünnîlik ile yine içinde itikâdi ve fıkhi mezhepleri barındıran bir çerçeve anlayış olan Şîilik mukayese edilebilir türdeşlerdir. Ancak Alevî gelenek de içine katılarak yürütülen Diyanet tartışmalarında Alevî gelenek mensubu ocak ve grupların tasavvufi kimliği ve mezhebî fiilî durumlarının dikkate alınması yerine; tartışmanın 90'lı yıllarda görülen kimlik politikaları çerçevesinde yanlış bir şekilde Sünnîlik karşısına konumlandırılmış bir pozisyon ve içeriklendirme ile yürütülmesi, olayı mecrası dışına taşımıştır. ${ }^{87} \mathrm{Bu}$ noktadaki tartışmaların sağlıklı olması adına öncelikle Alevî gelenek mensubu ocak ve grupların geleneksel olarak sahip oldukları tasavvuf karakteri ile mezhebî kabul ve uygulamalarının mutlaka göz önünde bulundurulması gerektiği aşikârdır.

Konunun çerçevesini açıklığa kavuşturmak adına -makale sınırlılıklarına bağlı olarak- burada söz konusu bu iki hususa kısaca değinmekte fayda vardır. Alevî gelenek mensubu ocak ve grupların her biri bir tasavvuf ve tarikat hayatı sürdüren topluluklardır. Nitekim her bir ocak farklı tasavvufi gelenek mensubiyetine ve

\footnotetext{
86 Metin Bozkuş, "Alevî Yurttaşlara Yönelik Dinî Hizmetlerin İcrası Bağlamında Bir Teklif Denemesi", Cumhuriyet Üniversitesi Ilahiyat Fakültesi Dergisi 10/1 (2006), 1-12; Sönmez Kutlu, "Diyanet İşleri Başkanlığı ve İslâmiçi Dini Gruplarla (Mezhep ve Tarikatlar) İlişkileri”, Dinı̂ Araştırmalar 12/33 (2009), 107-128; Gözaydın, Diyanet, 293-304. Alevî gelenek mensubu ocak ve grupların Diyanet'te temsili hakkındaki bazı çalışmalar için bkz. Şuayip Özdemir, "Avrupa Birliğine Giriş Sürecinde Alevilerin Diyanet İşleri Başkanlığında Temsil Meselesine Bakışı -Malatya Örneği-", Uluslararası Bektaşilik ve Alevilik Sempozyumu -I- (Isparta: Isparta İlahiyat Fakültesi Yayınları, 2005), 441-454; Ramazan Uçar, "Alevî-Bektâşîlerin Diyanet İşleri Başkanlığı'nda Temsil Problemi Üzerine (Alan Araştırması)", Uluslararası Bektaşilik ve Alevilik Sempozyumu (Isparta: Isparta İlahiyat Fakültesi Yayınları, 2005), 455-466.

87 Hasan Onat, "Değişim Sürecinde Alevîlik". Prof. Dr. Hasan Onat. Erişim adresi: http://www.hasanonat.net/index.php/99-degisim-suerecinde-alevilik; Cenksu Üçer, "Aleviliğin Neliği ve Şiilik (Caferilik) ile İlişkisinin Çerçevesi", Marife: Dini Araştırmalar Dergisi 8/3 (2008), 201-211.
} 
silsilelere sahip olup âdâb ve erkân açısından farklılıklar taşısa da bilgi kaynağı olarak kabul edilen ilham ve keşf, "Ulûhiyyet, Nübüvvet, Velâyet” prensibinin ifade şekli olan "Hakk, Muhammed, Ali" anlayışı, dört kapı- kırk makam çerçevesinde oluşturulan âdâb ve erkân, kelime-i tevhidlerin/Hûların getirilip zikirlerin çekildiği cemler, "eline, diline, beline sahip olmak/ edeb yâ Hû" ilkesi etrafında şekillendirilen ahlak anlayışı, "mürşid, pîr, şeyh, dede, rehber, tâlib (mürîd)" şeklinde hiyerarşik olarak oluşturulan insan unsuru ve ocak sisteminin uyarlandı̆̆ 1 bir tekke yapılanması vb. unsurlar, söz konusu geleneğe mensup ocak ve grupların tasavvuf ve tarikat hayatı bağlamında ele alınması gereken yapılar olduğunu açıkça ortaya koymaktadır. ${ }^{88} \mathrm{Bu}$ durum Alevî geleneğe mensup ocak ve gruplarla ilgili yapılacak her türlü tartışma ve çalışmanın, ancak geleneğin bu temel özelliği dikkate aldığında sağlıklı olacağını göstermektedir. Fakat Başkanlık hizmetleri bağlamı da dâhil Alevî gelenekle ilgili yapılan tartışmaların ve yürütülen bir takım siyasi/bürokratik işlemlerin bu çerçeveyi dikkate almadığı açıkça ortadadır.

Alevî geleneğe mensup ocak ve grupların mezhebî kabul ve uygulamalarına gelince: Günümüzde Alevî olarak isimlendirilen, geleneksel olarak ise Hacı Bektaş, Baba Mansur, Dede Garkın, Hasan Dede, Şücaaddin Velî gibi ocak isimleriyle ${ }^{89}$ anılan gelenek mensubu ocak ve grup müntesipleri, her ne kadar Caferî mezhebi ile alakalı bir takım sözlü beyanlarda bulunsalar da büyük oranda amelî uygulamalarında Hanefî mezhebinin esaslarına göre hareket etmektedir.90 Kamuoyunda yanlış konumlandırılabildiği üzere Alevî gelenek Şiîlik değildir. ${ }^{91} \mathrm{Bu}$ hususta Çorum Ehl-i Beyt Vakfı çevresi istisnadır. Zira bu vakıf çevresinde bir araya gelen gelenek mensupları, 1980'li yıllardan sonraki birtakım gelişmelere bağlı olarak İran etkisiyle Şiîleşerek Caferîlik esaslarını uygulamaktadır. ${ }^{92}$ Yeri gelmişken bu

\footnotetext{
${ }^{88}$ M. Saffet Sarıkaya, "Alevilik-Bektaşiliğin Tasavvufi Boyutu Üzerine”, Türk Kültürü ve Hacı Bektaş Veli Araştırma Dergisi 82 (2017), 9-23; Üçer, Alevî Ocakları ve Grupları, 62-73. Tasavvuf ve tarikat hayatının insani, fiilî, fikrî ve maddi ortak unsurları hakkında bkz. Mustafa Kara, Tasavvuf ve Tarikatlar Tarihi (İstanbul: Dergah Yayınları, 1990), 200-271; Ömer Yılmaz, Geçmişten Günümüze Tasavvufve Tarîkatlar (Ankara: Akçă̆ Yayınları, 2015), 199-216; Ali Bolat vd., Tasavouf Tarih, Doktrin, Tenkit (Samsun: E Yazı Yayınevi, 2019), 217237.

${ }^{89}$ Ali Yaman, Alevilikte Dedeler Ocaklar (İstanbul: Ufuk Matbaacılık, 1998); Hamza Aksüt, Aleviler TürkiyeIran-Irak-Suriye-Bulgaristan (Ankara: Yurt Kitap-Yayın, 2009); Mehmet Ersal, Alevilik Kavramlar ve Ocak Sistemi -Çubuk Havzası Örneği- (Ankara: Türk Kültürü ve Hacı Bektaş Veli Araştırma Merkezi Yayınları, 2016).

90 İlyas Üzüm, “Alevilerin Caferi Mezhebine Mensubiyetinin Arka Planı: Alevilik-Caferilik İlişkisi veya İlişkisizliği”, İslâmiyât 4/3 (2003), 132-150; Sönmez Kutlu, Alevîlik-Bektaşîlik Yazıları, Alevîliğin Yazılı Kaynakları, Buyruk, Tezkire-i Şeyh Safì (Ankara: Ankara Okulu Yayınları, 2008), 48-52; Ömer Faruk Teber, Bektâşî Erkânnâmelerinde Mezhebi Unsurlar (Ankara: Aktif Yayınları, 2008), 124-129; Üçer, “Aleviliğin Neliği ve Şiilik (Caferilik) ile İlişkisinin Çerçevesi", 221-234; Mehmet Saffet Sarıkaya- Mustafa Ceylan, "Şeyh Çakır Ocağı Mensuplarının İnanç Esasları ve İbadetler Hakkındaki Kabulleri", Süleyman Demirel Üniversitesi Illahiyat Fakültesi Dergisi 40 (2018/1), 175-176.

${ }^{11}$ Hasan Onat, "Kızılbaşlık Farklılaşması Üzerine”, İslâmiyat 6/3 (2003), 111-126. Ömer Faruk Teber, "Mezhebî Ayrışmanın Politik Sonuçları: Safevî Tarikatının Siyasallaşması", Illahiyat Akademi: Altı Aylık Uluslararası Akademik Araştırma Dergisi 5 (2017), 193-200.

92 Üzüm, "Alevilik-Caferilik İlişkisi veya İlişkisizliği”, 149; Ahmet Taşğın, "1980 Sonrası Alevilerin Farklı Bir Görüntüsü: Alevi Caferiler ve Aşura Dergisi”, Dinî Araştırmalar 7/18 (2004), 144-146; Şaban Banaz,
} 
noktada iki hususa daha işaret etmekte fayda vardır. Birincisi, son yıllarda Alevî geleneğe mensup ocak ve gruplar arasında bir nevi Şiîleştirme çabası gözlemlendiği ifade edilmelidir. Söz gelimi gelenekte salâvâtlar geleneğe ait eserlerde diğer Müslüman ekollerde olduğu gibi kaydedilmekte ve buna göre okunmakta, ${ }^{93}$ cenaze namazları da 4 tekbirle Hanefî usulle kılınmaktadır. ${ }^{94}$ Ancak işaret edilen çabalar bağlamında salâvâtlara "âlihî/ailesi" kelimesinden sonra aynı anlama gelen "Ehl-i beytihî/ev halkı" ifadesinin eklenmesi ya da cenaze namazlarının 5 tekbir ile kılınması için bir gayret gösterilmesi bu meyanda zikredilebilecek hususlardandır.

İkinci olarak işaret edilen inşa sürecine dair gayretlerin hâlâ sürdürüldüğü bağlamında da cenaze namazlarıyla ilgili uygulamaları zikretmek konuyu daha anlaşılır kılacaktır. Zira geleneksel olarak Hanefî usulle kılınan cenaze namazlarının yerine son zamanlarda belli çevrelerce -gelenek içinden kuvvetli itirazlara rağmendeyiş, düvaz okunması vb. birtakım unsurlar cenaze namazı yerine ikame edilmeye çalışılmakta ya da cenaze namazında okunan dualara birtakım müdahaleler yapılmaktadır. Nitekim İlahiyatçı bir Ocakzâde (Dede) olan merhum Mehmet Yaman ilk baskısı 1993 yılında yapılan Alevîlik adlı kitabında cenaze hizmetlerini ele aldığı kısımda ilk tekbirde "Sübhâneke" okunur derken; 1999 yılında basılan Cenaze Hizmetleri adlı kitabında birinci tekbirde tekbir kelimesi okunur denilerek tekbir kelimesi olarak da "Lâ ilâhe illallâh Muhammed Rasûlüllâh Aliyyün Veliyyullâh" ibaresinin zikredilmesi ${ }^{95}$ oldukça dikkate değerdir.

Tekke ve zâviyeler kapatılmadan önce her bir ocak âdâb ve erkânını tekke, zâviye ve dergâh merkezli甲9 teşkilatlanan ocak sistemi üzerinden yürütmüştür. Alevî gelenek bugün dahi daha çok bu sistem üzerinden âdâb ve erkânını yürütmektedir. ${ }^{97}$ Başkanlığın 1924'ten bu yana Alevî geleneğe mensup ocak ve gruplar dâhil hiçbir tasavvuf ekolünün gerek tekke ve dergâhı gerek âdâb ve erkânı kapsamında herhangi bir görev tanımı bulunmadığı gibi bu meyanda herhangi bir hizmeti de olmadığı açıktır. Bu itibarla bu gerçek görmezden gelinerek yapılacak olan Alevî

\footnotetext{
"Çorumlu Caferileşmiş Alevilerin Caferileşme Süreçleri ve Temel İnanç Esasları", Türk Kültürü ve Hacı Bektaş Veli Araştırma Dergisi 95 (2020), 170-179.

${ }_{93}^{33}$ Cenksu Üçer, "Cemlerde Kur'an'ın Türkçe Meâlinin Okunması Üzerine Bazı Mülâhazalar", Türk Kültürü ve Hacı Bektaş Veli Araştırma Dergisi 84 (2017), 77-78.

${ }^{94}$ Mehmet Yaman, Alevîlik İnanç-Edeb-Erkân (İstanbul: 2001), 336.

${ }^{95}$ Yaman, Alevîlik, 336; Mehmet Yaman, Alevilikte Cenaze Hizmetleri (İstanbul: 1999), 27.

${ }^{96}$ Anadolu ve Balkanlar'daki tekke ve dergâh kayıtları için bkz. Eraslan Doğanay, Anadolu'da Yaşayan Dergahlar (İstanbul: Can Yayınları, 2000), 47-142; Baki Öz, Dünyada ve Türkiye'de Alevi-Bektaşi Dergâhları (İstanbul: Can Yayınları, 2001), 13- 330. Geleneğin ana tekke ve alt tekke esaslı yapılanması için bkz. Cenksu Üçer,

"Alevî Nitelemeli Ocak/Gruplara Ait Tekke, Zâviye ve Dergâhlardaki Cami ve Mescidler", e-Makâlât Mezhep Araştırmaları 11/2 (2018), 271-307.

${ }^{97}$ Cenksu Üçer, "Alevî Nitelemeli Gelenek ya da Ocak ve Gruplar Hakkında Yapılacak Çalışmalarda Ocak Sisteminin Dikkate Alınmasının Önemi", e-Makâlât Mezhep Araştırmaları 12/2 (2019), 353-402. Tekke ve dergâhların; Tokat Hubyar örneğinde görüldüğü üzere kimi fiilen çalışan yine Tokat Keçeci Baba ve Hacı Bektâş örneğinde görüldügüu üzere kimi ise bir ziyâretgâh konumuna taşınan pozisyonlarıyla bu sistemin içinde yer almaya devam ettiği ifade edilmelidir.
} 
geleneğin statüsünden ana dilde ibadete, âdâb ve erkânın icrâ edildiği mekanlar olan cemevlerinden ${ }^{98}$ Başkanlıkla ilgili hizmetlere varıncaya kadar her türlü tartışma, çalışma ve işlemin, mecrası dışında yürütülmesine bağlı olarak sağlıksız ve isabetsiz olacağında şüphe yoktur.

\section{Diyanet İşleri Başkanlığı ve Dinî Söylemi}

\subsection{Dinî Söylem}

Din ve dine dair olguların anlaşılması ve bunların aktarımı dil aracılığı ile olduğu için din-dil ilişkisi son derece önemlidir. Nitekim dinin dil ile anlaşılması, dilin ise dinden etkilenmesi nedeniyle bu iki unsur arasındaki karşılıklı ilişki bağlamında; mahiyetleri, keyfiyetleri ve birbirine etkileri hususunda din dili, dinin dili, dinî dil vb. tamlamalarla konunun farklı boyutlarıyla ele alınmaya çalışıldığı görülmektedir. ${ }^{99}$ Dinî düşünce ve hayat, dinî metinlerin "dil, zihniyet ve toplumsal yapılar çerçevesinde zamanda ve mekanda meydana gelen her türlü siyasi, ekonomik, kültürel, ilmî gelişmeler" doğrultusunda anlaşılmasına göre şekil almaktadır. Dolayısıyla gerek fertlerin gerek grupların din söylemi buna göre ortaya çıkmaktadır. ${ }^{100} \mathrm{Bu}$ durum -yukarıda işaret edildiği üzere- İslâm tarihinde ortaya çıkan siyasi, itikâdi, fıkhi-amelî, tasavvufi ve felsefi mezhep ve düşünce ekollerinin zihniyet açısından sınıflandırılması örneğinde açıkça görülmektedir.

Başkanlığın dinî söylemini işlerken çerçeveyi netleştirmek adına Bardakoğlu'nun konu hakkında yaptı̆̆ı açıklamayı dikkate almanın yerinde olacağı anlaşılmaktadır. Din söylemini “din adına konuşmak, din üzerine konuşmak ve bir şeyi dinle ilişkilendirmek şeklinde üç gruba ayırma"nın mümkün olduğunu belirten Bardakoğlu, "İslâm dini açısından birinci ihtimalin geçerli olmadığını, çünkü İslâm'da dinin vaz'ının Allah'a, onun tebliğ ve açıklamasının ise Rasûlü'ne ait

\footnotetext{
${ }^{98}$ Fevzi Rençber, Tarihsel ve Kültürel Boyutlarıla Alevîlikte Cem ve Cem Evleri (Şırnak: Şırnak Üniversitesi Yayınları, 2018); Cenksu Üçer, "Cemevi: Âdâb ve Erkânın İcrâ Edildiği Mekân”, Türk Kültüurü ve Hacı Bektaş Veli Araştırma Dergisi 88 (2018), 59-84; Ahmet Taşğın, "Cem, Cemevi ve İşlevleri", Geçmişten Günümüze Alevî-Bektaşî Kültürü̈, ed. Ahmet Yaşar Ocak (Ankara: T.C. Kültür ve Turizm Bakanlığı Yayınları, 2009), 211-225.

99 Turan Koç, Din Dili (İstanbul: İz Yayıncllık, 1998); Ali Yıldırım, "Din Dili Dinî Dil Ayırımı", Gaziosmanpaşa Üniversitesi Sosyal Bilimler Araştırmaları Dergisi 11/1 (2016), 323-330; Cem Zafer, "Dinî Alanda Dilin Kullanımı ve Etkileri", Akademik Sosyal Araştırmalar Dergisi 7/89 (2019), 627-640. Nitekim klasik fıkıh usulü eserlerinin mukaddimelerinden hemen sonra gelen ilk bölümlerinde Kur'an ve dil meselesini ele aldıkları bilinmektedir. Murteza Bedir, “Usûl-i Fıkhın Geçmişte ve Günümüzdeki Müfredatı -Fıkıh Usûlü Tasavvurunda Büyük Değişim: Fıkıh Usûlü Ders İçeriği Üzerinden Bir İnceleme", Kelâm İlmi ve İslâm Hukukunda İçerik Sorunları: Tartışmalı İlmî İhtisas Toplantısı (İstanbul: Üsküdar Belediyesi Yayınları, 2017), 316-322.

100 Ahmet Yaman İslâm dünyasında klasik olarak kabul edilen eserlerin her birinin kendi zaman ve mekanındaki zihniyet kodları üzerinden kaleme alınmaları nedeniyle ortak bir din dili inşa etmenin zorluğuna işaret etmektedir. Ahmet Yaman, "Klasikler Üzerinden Ortak Bir Din Dili Oluşturulabilir mi?", Türkiye IV. Dini Yayınlar Kongresi:Dini Klasikler: Tebliğler-Müzakereler (Ankara: Diyanet İşleri Başkanlığı Yayınları, 2011), 247-250.
} 
olduğunu, buna bağlı olarak Tanrı adına açıklamada bulunabilen bir din adamı sınıfının baştan reddedildiğini" ifade etmektedir. Bu durumda, "din söylemini, din üzerine konuşmak ve hâdiseleri dinle ilişkilendirmek şeklinde iki şıkka indirmek gerekir. Birincisi, dinin ana öğretisinin tanıtımı, ikincisi ise dinin dolaylı ilgi alanlarının tespiti ya da üretilmesi anlamına gelir."101 Bu itibarla bu çalışmamız Başkanlığın dinin ana öğretisinin tanıtımında ya da dinin ilgi alanları hakkında nasıl bir tavır takındığı meselesini ele almayı amaçlamaktadır.

\subsection{Başkanlığın Dinî Söylemi Bağlamında Cumhuriyet Dönemi Gelişmeleri ve Başkanlar}

Bu kısma başlarken öncelikle Başkanlıkla ilgili olarak 1924'ten 1950'ye, 1950 'den $1965^{\prime} \mathrm{e}, 1965^{\prime}$ ten $1982^{\prime}$ e, $1982^{\prime}$ den $2010^{\prime}$ a, $2010^{\prime}$ dan $2018^{\prime}$ e ve sonrası şeklinde bir tarihlendirme yapılması hakkında yukarıda işaret edilen hususa ilaveten asıl olarak Türkiye' deki dinî düşünce ve hayatın da gerek dünyada gerek ülkede yaşanan gelişmelere göre şekil aldığı ve alacağı hususuna vurgu yapmak yerinde olacaktır. Nitekim 1980'li 90'lı yıllarda yaşanan gelişmeler bunun için güzel bir örnek teşkil etmektedir. Dünyada ve ülkede modernite, küreselleşme ve şehirleşmenin etkilerine ek olarak ülkeden farklı ülkelere gidiş-gelişler, Arap dünyasından bazı kitapların Türkçeye çevrilmesi ya da İran'da yaşanan siyasî gelişmelerin ülkeye etkisi vb. farklı etkenlere bağlı olarak Türkiye'nin dinî düşünce ve dinî-kültürel hayat pratiklerinde bazı çevrelerde daha belirgin olmak üzere bir takım değişim ve dönüşümler yaşanmıştır. Bu bağlamda söz gelimi Mehmet ismi Muhammed'e, edille-i şe'iyye'nin 'Kitap' ' 'Kur'an'a dönüşmüş, ${ }^{102}$ Cuma namazı hakkında belli çevrelerde tartışmalar ortaya çıkmış, yine genele şâmil olmamakla birlikte belli çevrelerde Cuma namazının sünnetleri de dahil sünnet namazları, cemaatle tesbihat ve dua uygulamalarında bir değişiklik yaşanması hususunda tartışmalar yaşanmış, yüzyıllardır Anadolu'dan Kafkaslar'a, Kafkaslar'dan Balkanlar'a bu topraklar ve çevresindeki geniş bir coğrafyada dinî duyguyu beslemenin yanında dinî aidiyet ve kimlik kazandırma konusunda önemli fonksiyonlar icra eden -hatta bazı zamanlar Balkanlar ve Kafkaslar örneklerinde olduğu üzere eldeki tek unsur olarak kalan- mevlitlerin

\footnotetext{
${ }^{101}$ Ali Bardakoğlu, "İlahiyatçıların Din Söylemi", İslâmiyât 4/4 (2001), 63. Türkiye'deki İlahiyatçıların din söylemini ele aldığı çalışmasında Bardakoğlu, bu konuda genel olarak görülen problemleri "tarihsel tecrübenin tanıtım yöntemi, gerçek ve tek bir İslâm tasavvuru, totaliter uslûp ve kuşatıcı din anlayışı" şeklinde tasnif ederek işlemektedir. Bardakoğlu, "İlahiyatçların Din Söylemi”, 65.

${ }^{102}$ Bu coğrafyadaki yerleşik dinî kültüre göre Hz. Peygamber'le ilgili kabullere bağlı olarak -istisnalarının olması muhakkak olmakla birlikte- çocuklara doğrudan Muhammed ismi verilmemiş; yerine Mehmet ismi tercih edilmiştir. Ancak 80'li 90'l1 yıllarda artık çocuklara Muhammed isminin verilmesinin yaygınlaşmaya başladığı görülmektedir. Asırlardır metodik dinî bilgiye göre edille-i şer'iyye (şer'î/dinî deliller) Kitap, Sünnet, İcma ve Kıyas olarak sıralanmışken; söz konusu dönemlerdeki etkiye bağlı olarak Kur'an ve Sünnet (belki de ayet ve hadisler) söyleminin dile getirildiğine şahit olunmaktadır. Bu iki durumun söz konusu etkilere bağlı olarak gerek kültürel gerek ilmî gelenek açısından bahsedilen diğer örnekleri de şekillendiren köklü bir zihniyet kırılması ve dönüşümüne işaret ettiği değerlendirilmektedir.
} 
önemsizleştirilmesi ya da kaldırılması gayretleri ve tartışmaları yürütülmüş, 20 rekat kılınan teravih namazları hakkında yine yaygın olmamakla birlikte farklı tartışmalar ve uygulamalar baş göstermiş, Perşembe akşamları okunan tecdîd-i iman ve tecdîdi nikahlar büyük oranda terkedilmiş, 103 annelerin abdest almadan çocuklarını emzirmediklerine dair bir tasavvurun anlatıldığı bu topraklarda kimi çevrelerde anneler ve anne adaylarının çocukları emzirmek durumunda olmadıkları hususunda görüşler dile getirilebilmiş, yine kimi çevrelerde Ramazan ayının ya da Bayramının tespiti -asırlardır bu topraklarda muvakkithaneler ve kurulduğu yıllardan bugüne de Diyanet İşleri Başkanlığında Vakit Hesaplama birimi olmasına rağmen- yurt dışından gelen telefonlarla yapılmak suretiyle aynı ailede farklı günlerde oruçlar tutulup bayramlar eda edilmeye başlanmıştır.

Konumuzun asıl çerçevesine gelecek olursak tevârüs edilen kurumsal tecrübeye bağlı olarak genel idare içerisinde yer verilen Başkanlığın dinî söyleminin ana çerçevesinin, yine tevârüs edilen ilmî gelenek daha çok Hanefî-Mâturîdî gelenek olduğu için akılcı-hadari bir mahiyette olması doğal olarak beklenen bir durumdur. Başkanlığın dinî söyleminin ana çerçevesinin tevârüs edilen söz konusu kurumsal tecrübe ve ilmî geleneklerle birlikte asıl olarak Cumhuriyet tarihinde yaşanan gelişmeler doğrultusunda süreç içerisinde kanunla belirlenen yetki alanıyla yakından ilişkili olacağı aşikârdır. Ayrıca söz konusu gelişmelerin hem dilin bizzat kendisine hem kurumların yapısı ve hizmet anlayışına hem de dinî söyleme tesir edeceği muhakkaktır. Bu itibarla öncelikle Cumhuriyet dönemindeki içte ve diştaki siyasi, askerî, iktisadi, kültürel ve sosyal şartlara bağlı olarak yaşanan gelişmeler çerçevesinde başta din-devlet ilişkilerinin seyri, devlet idaresindeki siyasi kadroların din, dinî konular ve din-devlet ilişkilerine dair yaklaşımı; din işlerini yürütmek üzere görevlendirilen, öncelikle Başkanlar olmak üzere görev yapan kadroların zihniyet, kabiliyet, maharet ve hizmet anlayışlarının ${ }^{104}$ göz önünde bulundurulması yerinde olacaktır.

\footnotetext{
${ }^{103}$ Burada özellikle tecdîd-i nikah konusunda, dinî metinlerde nikahla ilgili olarak akit (karı-koca arasındaki hukuki antlaşma), ahid (karı-koca arasında evliğin gereklerini yerine getirmeye dair ahlâki ahitleşme) ve mîsâk (evliliğin gerekleri hakkında Allah'a verilen söz) kavramlarının ihmal edildiği; olayın sadece akit boyutuna indirgenip özellikle mîsâk boyutunun gözden kaçırıldığı anlaşılmaktadır. Zira tecdîd-i imanda "tecdîden bi-kavli lâ ilâhe illallâh..." ifadeleriyle mîsâk'ın yenilendiği açıktır. Bu konuda Diyanet İşleri Başkanlığının 3 Şubat 2017 tarihinde okuttuğu hutbe metnine bakılabilir. Diyanet İşleri Başkanlığı, Hutbe (03.02.2017). Hutbenin ilgili kısımlarını hutbe metnine bizzat kendisinin yerleştirdiğini bildiğimiz Başkan Mehmet Görmez bu ayrıntının Kazan âlimlerince açıkça vurgulandığını ifade etmiştir. ${ }_{104}$ Diyanet İşleri Başkanlığı Yüksek İhtisas Merkezlerinde eğitim-öğrenim gören ve geleceğin vaiz ve müftü adayı olan kursiyerlerin, çağımızın dinî nitelikli problemleri, toplumla ilgili olarak "geleneksel bir toplum olduğu, modernleşme sürecinde olan ya da modernleşen bir toplum olduğu" hakkında ya da toplumun bugünkü problemlerine hangi bilim dalının daha iyi çözüm üretebileceği hususlarındaki kanaatlerinin birbirinden farklı olduğu görülmektedir. Buna göre kursiyerlerin \%82,3'ü modernleşme sürecinde olan, 15,7'si geleneksel, \%2'si ise modernleşmiş bir toplum olduğu kanaatindedir. Toplumun bugünkü problemlerine hangi bilim dalının daha iyi çözüm üretebileceği konusundaki soruya kursiyerlerin \%98,9'u fıkıh, \%98,3'ü hadis, \%96,9'u tefsir, \%94,3'ü din eğitimi, \%93,4'ü Akaid ve Kelam ilmi şeklinde cevap vermiştir. Mustafa Asım Coşkun, Geleneksellik ve Modernlik Ekseninde Diyanet İşleri
} 
Bu çerçeve Başkanlık hakkında yapılan farklı çalışmalarda teyit edilmiştir. Nitekim görev yapan Diyanet İşleri Başkanlarının Türkçe ezan, başörtüsü vb. dinî hayat ve bazı uygulamalar hakkında dönemlerindeki güncel tartışmalar karşısında sergiledikleri tavırla ilgili kayıtlar bunu açıç̧a göstermektedir. Söz gelimi Başkanlığın konuya rızası olmadığı anlaşılsa da ${ }^{105}$ Diyanet İşleri Reisi Rifat Börekçi 1927 yılında hutbelerin, 1933 yılında ise salâ ve tekbirin Türkçeleştirilmesi hakkında bütün müftülüklere talimat ve genelge gönderirken; Diyanet İşleri Reisi Ahmet Hamdi Akseki 1948 yılında "Riyasetin İçişleri Bakanlığı ile yaptığı görüşmeler sonucunda" ezan ve kamet dışındaki tekbirlerin Arapça okunabileceği; 1950 yılında Hükümet tarafından hazırlanan kanun teklifine bağlı Meclis tarafından ezanın Arapça okunması yasağının kaldırılmasının ardından da ezan ve kametin aslî şeklinde okunması hakkında tamimler göndermiştir. ${ }^{106}$ 1950'de kaldırılan yasak, 1960'lı yıllarda tekrar gündeme getirilmeye çalışılmış, hatta Devlet ve Hükümet Başkanı Cemal Gürsel tarafından bizzat dile getirilmiş, akabinde basın yayın bu meyanda yayınlar yapmış; ancak Cemal Gürsel tarafından atanan dönemin Diyanet İşleri Başkanı Ömer Nasuhi Bilmen ezanın Arapça okunması gerektiğini söylemiştir.107 Başkan Süleyman Ateş Diyanet Gazetesi'nin 1 Şubat 1978 tarihli 182. sayısında Başkan olarak kaleme aldığı "Din Siyasete Âlet Edilemez" adlı son yazısında o gün itibariyle Diyanet İşleri Başkanlığına farklı çevrelerce yöneltilen eleştirilere cevap vermiştir. ${ }^{108}$ Başkan Tayyar Altıkulaç nüfus planlaması -bu konuda devletin eğitim ve yönlendirme politikalarını uygun görmekle birlikte-109 ve başörtüsü hususlarında Din İşleri Yüksek Kurulunu da devreye sokarak o dönemde devlet idaresinde bulunan kadroların arzu ettikleri anlaşılan uygulamaların aksine de olsa dinin hükümlerini paylaşmıştır. ${ }^{110}$

Başkanlığın bürokratik bir kurum olmasının yanı sıra ilmî bakımdan özerklik -ki Başkanlığın bunu daha çok Din İşleri Yüksek Kurulu vasıtasıyla sağladığı malumdur- ve din hizmetinin tabiatına istinaden sivil hizmet yönüne daima vurgu yapan Başkan Ali Bardakoğlu ${ }^{111}$ döneminde bilgiye dayalı ahlâk eksenli bir dindarlık

\footnotetext{
Başkanlı̆̆̆ Hizmet İçi Eğitim İhtisas Kursları (İstanbul: İstanbul Üniversitesi, Sosyal Bilimler Enstitüsü, Doktora Tezi, 2010), 72-79.

${ }^{105}$ Aydın, "Şeyhülislâmlıktan Diyanet İşleri Başkanlığına", 225; Okumuş, “Dindarlık ve Diyanet", 40.

${ }^{106}$ Kuruluşundan Günümü̈e Diyanet İşleri Başkanlığı, 501-503.

${ }^{107}$ Duman-Aydın, "Türkçe Ezan", 2272-2274.

108 Süleyman Ateş, “Başyazı: Din Siyasete Âlet Edilemez”, Diyanet Gazetesi 182 (1978), 1, 14-15.

${ }_{109}$ Başkanlık görevinden ayrıldıktan sonraki bir tarihte kaleme aldığı bu yazısında Altıkulaç eğitim ve yönlendirme politikaları açısından devletin birtakım tedbirler alabileceğini ifade etse de çocuk sayısını sınırlamak ya da kürtaj vb. müdahaleleri uygun görmemekte, burada da Din İşleri Yüksek Kurulunun kararlarına yer vermektedir. Tayyar Altıkulaç, "İslâm ve Doğum Kontrolü”, Diyanet İlmi Dergi 14/1 (1988), 26-35. s. 5-36

110 Tayyar Altıkulaç, Zorlukları Aşarken (Ankara: Türkiye Diyanet Vakfı Yayınları, 2016), 2/645-666.

111 Okumuş, “Dindarlık ve Diyanet", 41. Bardakoğlu'nun konuşmaları ve açıklamalarıyla derlenen eserde bilgiye dayalı ahlâk eksenli bir dindarlık vurgusu açıkça görülmektedir: Ali Bardakoğlu, 21. Yüzyıl Türkiye'sinde Din ve Diyanet (Ankara: Diyanet İşleri Başkanlığı Yayınları, 2010), 1/21-45, 184-198.
} 
ön plana çıkartılarak sosyal içerikli din hizmeti üzerinde durulmuş ${ }^{12}$ ve bu bağlamda cezaevlerinde irşad hizmetleri ya da Aile İşsad Büroları vb. yeni hizmetler oluşturulmuş; ayrıca 90'lı yıllardaki kimlik politikalarının dinî alana yansımaları çerçevesinde ülkedeki farklı mezhebî ve meşrebî mensubiyetlere sahip vatandaşları dikkate alan bir yaklaşım sergilenmiş, ${ }^{113}$ bu kapsamda söz gelimi Şâfîlik İlmihali, Caferîlik İlmihali, Alevî Bektâşî Klasikleri -Klasikler Diyanet Vakfınca yayımlanmıştır.- vb. eserler neşredilmiştir. 1970'li yıllarda Avrupa merkezli yurt dışındaki vatandaşlara yönelik başlatılan, Tayyar Altıkulaç'ın başkanlığında kurumsallaşması hususunda önemli adımların atıldı̆̆ı, 1990'lı yıllarda Sovyetler Birliği'nin dağılmasıyla bağımsızlıklarını kazanan Türk Cumhuriyetleri'nden gelen taleplerle Başkan Mustafa Said Yazıcıŏ̆lu döneminde başlayıp ${ }^{114}$ Başkan Mehmet Nuri Yılmaz döneminde genişleyen, Ali Bardakoğlu'nun başkanlığı döneminde dünyada ve yakın coğrafyamızda yaşanan gelişmelere bağlı olarak büyüyen yurt dışı hizmetleri, yine gelen taleplerin karşılanması adına yürütülen çalışmalarla oldukça genişlemiş ve Başkanlık Başkan Mehmet Görmez döneminde -Burada Türkiye'nin dünyadaki konumuna dair gelişmelerin dikkate alınması gerektiği açıktır.- Asya'dan Avrupa'ya, Afrika'dan Amerika'ya yaklaşık 120 ülkede temsilciliği bulunan ${ }^{115}$ bir kurum hâline gelmiştir. Başkanlığın hizmetlerinin çok geniş bir coğrafyada talep görmesinde İslâm'ın ortak değerleri üzerinden ve her coğrafyanın kendi hassasiyetlerini dikkate alan bir nevi mezhepler üstü hizmet anlayışının ve doğal olarak din söyleminin etkili olduğunda şüphe yoktur.

\subsection{Din İşleri Yüksek Kurulu, Diğer Birimler ve Hizmetler}

Diyanet İşleri Başkanlığının dinî söylemi bağlamında kuruluşundan bugüne Başkanlık bünyesinde yer alan farklı birimlerin faaliyetlerinin ayrı ayrı incelenmesi gerektiği açıktır. Bu meyanda başta Diyanet İşleri Başkanlarının konuşmaları, yazıları, basın açıklamaları, çeşitli vesilelerle yayımladıkları mesajlar olmak üzere Din İşleri Yüksek Kurulunun kararları, mütalaaları, fetvaları, Din Şûraları ve Din İşleri Yüksek Kurulu İstişâre Toplantıları sonuç bildirgeleri, hutbeler, Kurul onayından geçerek yayımlanan vaaz kitapları, basılı yayınlar, süreli yayınlar, takvimler, Avrasya İslâm Şûraları, Dini Yayın Kongreleri ve İl Müftüleri İstişare Toplantıları sonuç bildirgeleri ayrı ayrı; hatta kendi içinde de dünyada ve ülkede yaşanan siyasi, sosyo-ekonomik ve kültürel gelişim ve değişimler, bu gelişim ve değişimlerin yaşandığı ana zaman aralıkları, mevzuatta yaşanan değişiklikler vb. farklı ölçeklerde değerlendirmeye tabi tutulabileceğinde şüphe yoktur.

\footnotetext{
112 Bardakoğlu, Din ve Diyanet, 1/86-92.

${ }^{113} \mathrm{Kutlu}$, “Diyanet İşleri Başkanlığı ve İslâmiçi Dini Gruplar”, 120.

${ }_{114}$ Mustafa Said Yazıcıoğlu, Ne Yan Yana Ne Karşı Karşıya Anılar (İstanbul: Alfa Yayıncılık, 2013), 226-240.

${ }^{115}$ Diyanet İşleri Başkanlığ 1 (DİB), 2011-2013 Yılları Faaliyetler ve Raporlar (Ankara: Diyanet İşleri Başkanlığ Yayınları, 2013), 92.
} 
Başkanlığın dinî söylem ve hizmetlerinin ülke ve dünyada yaşanan gelişmelere göre şekil aldığı hususu gerek hutbeler gerek takvimin yaprak arkası yazıları konusunda yapılan çalışmalarda da kendisini göstermektedir. 1968'den 1991'e 23 yılda Diyanet Gazetesinde yayımlanan ve bütün ülkede okunan 757 hutbenin 34'ü inanç ve ibadetle, 12'si hacla, 10'u cami ile ilgiliyken; 29'unun orduyu teçhiz, vatan sevgisi ve zaferlerimizle, yine 29'unun sağlıkla, 20'sinin millî birlik ve beraberlikle, 12' sinin ağaç yetiştirme ve ormanlarla, 9'unun ise çalışma hayatı ile ilgili olması bunu açıkça ortaya koymaktadır. ${ }^{116}$ Hutbeler hakkında yapılan diğer bir çalışmaya göre 1999 yılında okunan hutbelerin \%30'u itikat, ibadet ve ahlak, \%30'u dinî-millî gün ve geceler, \%40'1 ise sevgi, barış, kardeşlik, çevre, sağlık gibi sosyal konularda hazırlanmıştır. ${ }^{117} \mathrm{Bu}$ çerçevenin Cumhuriyetin ilk yıllarında okunan hutbelerde de söz konusu olduğu görülmektedir. ${ }^{118}$

Diyanet Takvimi yaprak arkası yazılarında 2002 (Mehmet Nuri Yılmaz), 2007 (Ali Bardakoğlu), 2011 (Mehmet Görmez) yıllarında iman, ibadet, ahlak, millî ve mânevi değerlere yer verilmesi üzerine yapılan bir çalışma, dönemlere göre vurgu yapılan konular, yoğunlukları ve ifade edilme biçimleri hakkında farklılıkları ortaya koyması açısından dikkat çekicidir. Buna göre iman konularına 2002'de 42, 2007'de 74, 2011'de 91; ibadetlere 2002'de 114, 2007'de 178, 2011'de 201; ahlâk konularına 2002' de 55, 2007'de 120, 2011'de 86; millî ve mânevi değerlere 2002'de 506, 2007'de 336, 2011'de 311 defa yer verilmiştir. ${ }^{119} \mathrm{Bu}$ durumda bütün konulara her üç Başkan döneminde önemli ölçüde yer verilmiş olup hepsinde daha çok millî ve mânevi değerler vurgulanmış olsa da konulara göre değerlendirildiğinde söz gelimi millî ve mânevi değerlerin Mehmet Nuri Yılmaz, ahlâk konusunun Ali Bardakoğlu, iman ve ibadetlerin Mehmet Görmez döneminde diğer Başkanlara nazaran daha çok ön plana çıkartıldı ğı görülmektedir.

Bu noktada dikkate alınması gereken en önemli birim şüphesiz Din İşleri Yüksek Kuruludur. Zira 2010 yılında "dinî konularda" ifadesiyle yetkilerini sınırlayıcı bir belirleme yapılmış olsa da Din İşleri Yüksek Kurulunun 1965'ten 2010 yılına kadar Kanunla belirlenen en temel özelliği "Başkanlığın en yüksek karar ve danışma organı" olmasıdır. Kanunun Kurula bu bağlamda tanıdığı söz konusu yetkisi çerçevesinde yüklediği görevlere göz atıldığında bu keyfiyet daha net görülmektedir. 1965 ve 1990 yıllarına ait Kanun metinlerinde Kurulun görevleri

\footnotetext{
116 Vahdettin Akgün, “Diyanet Gazetesinde Yayınlanan Hutbeler”, Diyanet İlmi Dergi 30/2 (1994), 77-79.

${ }_{117}$ Ahmet Onay, “Diyanet Hutbelerinin Muhteva Analizi: Diyanet İşleri Başkanlı̆̆g'nın 1999 Yılı Hutbeleri Örneği", İslâmî Araştırmalar 17/1 (2004), 3.

${ }^{118}$ Nitekim Cumhuriyetin ilk yıllarında okunan hutbelerde dinî konular yanında siyasi, sosyal, iktisadi ve askerî gibi farklı alanlarda hutbeler okunmuş, devlet haftada bir bu yolla toplumla irtibat noktasında hutbelerin gücünden yararlanma yoluna gitmiştir. Murat Kılıç, “Cumhuriyet'in İlk Yıllarında Devlet ile Vatandaş Arasında Bir İletişim Aracı Olarak Hutbeler", Çağdaş Türkiye Tarihi Araştırmaları Dergisi 17/35 (2017), 137-164.

119 Rıfat Atay-Halil Arslan, “Üç Dönem, Üç Takvim: 2002, 2007 ve 2011 Yılları Takvimleri Örneğinde Diyanet Söyleminin Analizi”, Dinî Araştırmalar 20/52 (2017), 147-155.
} 
arasında sayılan "dinî eserler telif ve tercüme etmek, Başkanlıkça yayınlanması istenen telif ve tercüme eserlerin yayımına karar vermek, tetkiki istenen eserler hakkında mütalaa bildirmek; hutbe ve vaazların esaslarını tespit etmek ve örnek metinler hazırlamak; Başkanlığın uzun ve kısa vadeli ana hizmet politikasını ve çalışma esaslarını tespit etmek, bu konuda ilgili birimlerce hazırlanacak teklifleri inceleyip görüş bildirmek"120 vb. hususlar söz konusu durumu açıkça ortaya koymaktadır. Bu bağlamda 2010 yılına kadar bütün hutbeler, vaaz kitapları, basılı, süreli bütün yayınlar -söz gelimi Çocuk Dergisindeki bir karikatür dâhil- ya Din İşleri Yüksek Kurulunca hazırlanmış ya da Kurulun onayından geçmiştir. Burada Diyanet İşleri Başkanı Lütfi Doğan ve Ali Bardakoğlu'nun bazı yazıları, konuşmaları, basın açıklamaları, söyleşileri vb. materyalden oluşan ve makalemizde de kaynak olarak kullandığımız eserlerin Din İşleri Yüksek Kurulunun (Doğan 02.01.1986 tarihli ve 1 sayılı; Bardakoğlu 05.05.2010 tarihli ve 45 sayılı) kararlarıyla basılmış olması dikkatlere sunulmalıdır. ${ }^{121}$ 2010'da Kanunla yapılan değişiklikle Başkanlık ana hizmet birimlerine uzmanlık kadroları verilip Kurulla ilgili "dinî konularda" tahsisi yapılınca, -her ne kadar Kurula zaman zaman incelenmek üzere söz gelimi eserler gönderilse de- hutbeler (Din Hizmetleri Genel Müdürlüğü), yayınlar (Dinî Yayınlar Genel Müdürlüğ̈̈) vb. hizmetler, ilgili birimler tarafından yürütülür hale gelmiştir.

Kanunun kendisine vermiş olduğu yetki bağlamında öteden beri Din İşleri Yüksek Kurulunun dinin temel kaynakları (Kitap ve Sünnet) ve başta haliyle fıkıh olmak üzere ilmî disiplinlerin metodolojisiyle karar verip "ilmî özerkliği" koruduğu anlaşılmaktadır. Kurulun farklı alanlarda güncel tartışmalar konusunda kamuoyu ile paylaştığı karar ve görüşleri bunu açıkça göstermektedir. Yukarıda değinilen nüfus planlaması ve başörtüsü örneklerinde görüldüğü üzere Kurul, farklı dönemlerde güncel olarak tartışılan ve gerek siyasi kadroların beklentilerinin gerek bürokratik mülahazaların gerekse popüler tartışmaların olduğu pek çok konuda söz konusu beklenti, mülahaza ve tartışmanın aksine de olsa 14 asırlık bilimsel tecrübe ve birikimi göz önünde bulundurup dinî konudaki tespitini paylaşmıştır. Mesela İmam Hatip Lisesinde okuyan kız öğrencilerin kıyafetleri, ${ }^{122}$ tesettür/başörtüsü, ${ }^{123}$

\footnotetext{
${ }_{120}$ Altunışık, Din İşleri Yüksek Kurulu, 140-141.

${ }^{121}$ Lütfi Doğan, Toplumun Temelini Sarsan Belli Başlı Problemler (Huzur ve Saadetin Esasları) (Ankara: Diyanet İşleri Başkanlığı Yayınları, 10. Baskı, 2016), jenerik sayfası; Bardakoğlu, Din ve Diyanet, jenerik sayfası.

122 Din İşleri Yüksek Kurulu, Millî Eğitim Bakanlığı'nın “kadınların örtülü kıyafetlerinin 'Atatürk ilkelerine tamamen aykırı' olduğunu ifade ettiği ilgili yazısına istinaden 30.12.1980 tarihli ve 77 sayılı Kararında; genel ahlaka ve kanunlara aykırı olmayan bir kıyafetin "Atatürk devrim ve ilkelerine aykırılığının söz konusu olmadığını", "kadınların başlarını örtmelerinin bir adet ve işaret değil, İslâm Dininin bir hükmü olduğunu" belirtmiştir. Altıkulaç, Zorlukları Aşarken" 3/1343-1349.

123 03.02.1993 tarihli ve 6 no.lu Kararında Kurul, başörtüsünün “Dinimizin, Kitap, Sünnet ve İslâm âlimlerinin ittifakı ile sabit olan kesin emri” olduğunu belirtmiştir. Din İşleri Yüksek Kurulu (DİYK) 1993/6 (03 Şubat 1993), https://kurul.diyanet.gov.tr/Karar-Mutalaa-Cevap/2471/tesettur-ile-ilgili-karar.
} 
Türkçe (ana dilde) ibadet ${ }^{124}$ hakkındaki karar ve mütalaalarını bu bağlamda zikretmek mümkündür.

Din İşleri Yüksek Kurulunun söz konusu yetki alanının 19. yüzyıl sonları ile 20. yüzyıl başlarında İslâm dünyasında yaşanan gelişmelere bağlı olarak şekillenen fikirlerle bağlantılı olduğu görülmektedir. Nitekim Osmanlı'nın son dönemleri ile Cumhuriyet'in ilk dönemlerinde ön planda olan kimi âlim ve düşünürler, içtihadın ferdî olmaktan çıkarılıp bir müessese (Meclis-i Âli-i İctihad, Heyet-i İlmiye) hâline getirilmesi fikrinden yana bir tavır sergilemişlerdir. ${ }^{125}$ Nitekim Osmanlı döneminin sonlarında Şeyhülislâmlık bünyesinde Dâru'-Hikmeti'l-İslâmiyye'ye, Millet Meclisi Hükümeti döneminde kurulan Şer'iyye ve Evkâf Vekâleti bünyesinde Heyet-i İftâiyye ve Tedkikat ve Te'lifât-1 İslâmiyye Heyeti'ne, Cumhuriyet döneminde kurulan Diyanet İşleri Reisliği bünyesinde ise Heyet-i Müşâvere'ye yer verilmiş olmas1 ${ }^{126}$ işaret edilen düşüncelerin fiiliyata dönüştüğünü göstermektedir. Dünya çapında yaşanan gelişmelere bağlı olarak heyet fetvası/içtihadı olgusu bugün itibariyle farklı bir mecraya evirilmiştir. Artık söz konusu heyetlerin temsilcilerinin oluşturduğu üst heyetler ya da meclisler teşekkül ettirildiği görülmektedir. ${ }^{27}$ Nitekim 11-14 Ekim 2016 tarihlerinde İstanbul'da toplanan Avrasya İslam Şûrası sonuç bildirgesinde (madde: 11) “...ayrıca Şûra bünyesinde icra komisyonuna ek olarak Fetva Komisyonu, Din Hizmetleri Komisyonu, Din Eğitimi Komisyonu, Hayrî ve İnsanî Yardımlar Komisyonu ve Medya ve Dinî Yayınlar Komisyonunun kurulması"nın ${ }^{128}$ kararlaştırılması üzerine Din İşleri Yüksek Kurulunun yürüttüğü çalışmalarla Avrasya Fetvâ Meclisi kurulmuştur. ${ }^{129}$

124 İslâm tarihinde "ana dilde ibadet"le ilgili tartışmalar Türkiye'de de söz konusu olmuştur. Halil Altuntaş,

"Türkçe İbadet Meselesi", Diyanet İlmi Dergi 34/1 (1998), 51; Kâşif Hamdi Okur, "Ebu Hanife ve Ana Dilde İbadet", İslâmî Araştırmalar 15/1-2 [Ebû Hanîfe Özel Sayısı] (2002), 83. Ülkemiz tarihinde zaman zaman gündeme geldiği anlaşılan Türkçe (ana dide) ibadet tartışmaları ülkemiz yakın tarihinde 28 Şubat dönemi olarak adlandırılan süreçte de tekrar yoğun bir şekilde gündeme gelmiş, Din İşleri Yüksek Kurulu 04.12.1997 tarihli ve 130 sayılı Kararında “Namazda ve ibadet olarak Kur'an-1 Kerim'in aslî lafızları ile okunacağını" belirtmiştir. Din İşleri Yüksek Kurulu (DIYK), 1997/130 (04 Aralık 1997), https://kurul.diyanet.gov.tr/Karar-Mutalaa-Cevap/2610/turkce-ibadet-meselesi.

125 İsmail Kara, Türkiye'de İslâmcllık Düşüncesi (İstanbul: Risale, 2. Baskı, 1987), 1/LXII; Kâşif Hamdi Okur, "Son Dönem Osmanlı Düşüncesinde Fıkıh Alanındaki Tartışma ve Yaklaşımlar", Türkiye Araştırmaları Literatür Dergisi 12/23 (2014), 15. Her ne kadar İslâm tarihinde ilk dönemlerdeki bazı uygulamalar heyet içtihadına örnek teşkil etse de, Din İşleri Yüksek Kurulu ve birkaç örneği hariç bunun yaygınlaşması oldukça yakın döneme ait bir gelişmedir. Mustafa Bülent Dadaş, "Bir Fetva Belirleme Yöntemi Olarak Heyet İçtihadı ve İslâm Dünyasında Bu Amaçla Kurulan Fıkıh Meclisleri", Bilimname: Düşünce Platformu 28 (2015/1), 311-339.

${ }^{126}$ Altuntaş, Din İşleri Yüksek Kurulu, 17-37.

${ }^{127}$ Dadaş, "Bir Fetva Belirleme Yöntemi Olarak Heyet İçtihadı”, 330-334.

${ }^{128}$ IX. Avrasya İslâm Şurası Sonuç Bildirgesi (14 Ekim 2016), https://avrasyaİslâmsurasi.diyanet.gov.tr/tr$\underline{\text { TR/Declaration/ Detail/9. }}$

${ }^{129}$ Avrasya Fetva Meclisi ilk toplantısını 10-11 Mayıs 2017'de Ankara' da gerçekleştirmiştir. Avrasya Fetva Meclisi (AFM) (10-11 Mayıs 2017), https://avrasyafetva.diyanet.gov.tr/sayfa/toplantilar/1-toplanti. 
İçtihadın ferdî olmaktan çok heyet tarafından yürütülmesi anlayışının Din İşleri Yüksek Kurulunu da şekillendirdiği görülmektedir. Nitekim son kanuni düzenlemelere göre Kurul Başkanı ve Başkanvekili ile beraber 16 üyeden oluşan Kurulun 12 üyesi, Diyanet İşleri Başkanlığının farklı kademelerdeki personeli, İlahiyat/İslami İlimler Fakülteleri öğretim üyeleri ve Din Öğretimi Genel Müdürü'nden oluşan Aday Tespit Kurulu tarafından, 4 üye ise Başkan tarafından İlahiyat/İslami İlimler Fakülteleri öğretim üyeleri arasından seçilmektedir. Kurul, kararlarını salt çoğunlukla almaktadır. Diyanet İşleri Başkanı'nın, Kurul toplantılarına katılıp başkanlık yapma yetkisi olsa da "karar için oy hakkı bulunmaması" burada önemle vurgulanmalıdır. ${ }^{130}$

Kurban, teravih namazı ve sigara içmenin hükmü örneklerinde görüldüğü üzere değişik konularda; Kurulun paylaştığı bilgilendirmeden farklı olmanın yanında asıl olarak gerek bu coğrafyadaki yerleşik ibadet hayatı kabulleri gerek yerleşik mezhebî görüş ve uygulamalar ile örtüşmediği için farklı tartışmalara neden olan bazı istisnai beyanları ve tasarrufları131 bulunmakla beraber Diyanet İşleri

\footnotetext{
${ }^{130}$ Kurulun kararları Diyanet İşleri Başkanı'na “Görüldü” formatıyla arz edilmektedir. Yani Başkan'ın Kurul kararlarını onaylama durumu söz konusu değildir.

131 Yukarıda işaret edildiği üzere Başkan Lütfi Doğan ve Ali Bardakoğlu'nun konuşmalarını, makalelerini vb. ihtiva eden eserler Din İşleri Yüksek Kurulu kararıyla yayımlanmışken; Başkan Mehmet Nuri Yılmaz'ın konuşmalarını, makalelerini vb. muhtevi eser, Başkanlık Makamının 13.06.1996 tarihli ve 302 sayılı; 26.11.1996 tarihli ve 627 sayılı onayları ile yayımlanmıştır. Diyanet İşleri Başkanlığı (DİB), Diyanet İşleri Başkanı Mehmet Nuri Yılmaz'ın Konuşmaları ve Makaleleri (Ankara: Diyanet İşleri Başkanlığı Yayınları, 1-7 cilt, 1996-2002), jenerik sayfaları.

Başkan Ali Bardakoğlu kamuoyunca da yakinen bilindiği üzere kurbanın dinî hükmünün "sünnet" olduğu şeklindeki görüşünü, Başkanlığının ilk yıllarında dile getirmiş ve bu noktada farklı tartışmalar yaşanmıştır. Ancak Kurul, kurbanın dinî hükmünün diğer mezheplerde sünnet olarak kabul edilse de Hanefîler nezdinde vacip olduğunu söylemektedir. Din İşleri Yüksek Kurulu, Fetvalar (Ankara: Diyanet İşleri Başkanlığı Yayınları, 4. Baskı, 2018), 345. Başkanlıkça 1990'lı yıllardan itibaren yürütülen ve Bardakoğlu'nun başkanlığı döneminde hız kazanan, hatta başkanlığında düzenlenen Afrika Müslüman Ülke ve Topluluklar Dini Kurum ve Kuruluş Temsilcileri Birinci Toplantısı Sonuç Bildirgesinde (Bardakoğlu, Din ve Diyanet, 2/455-459) Afrika'da vekâletle kurban kesilmesine dair karar alınmasına rağmen çıkartılan kimi zorlukları aşıp -ki bizzat şahit olunmuştur.- bu konudaki hizmet sınırlarını genişleten Bardakoğlu'nun döneminden (2006'da 16 ülkede 2.877, 2007'de 17 ülkede 4.572; 2010'da yurt dışında 30.123 vekâletle kurban kesilmiştir. Diyanet İşleri Başkanlığ1 (DİB), Faaliyet Raporu 2006, 52; Faaliyet Raporu 2007, 65; Faaliyet Raporu 2010, 37) bugüne (2021 yılında 77 ülkede 339 ayrı bölgede vekâletle kurban kesilmiştir. Türkiye Diyanet Vakfı, Kurban. https://tdv.org/tr-TR/faaliyetlerimiz/kurban.) gelinen bu noktada, her ne kadar sünnet dinî hüküm açısından zaten ihmal edilmemesi gereken bir unsur olsa da bu topraklardaki Müslümanlar nezdinde kurban ibadetinin vacip olarak görülmesinin ana etkenlerden biri olduğunda şüphe yoktur.

Başkan Mehmet Görmez döneminde 2011'den sonra yayımlanan Ramazan Genelgelerinde yer verilmek suretiyle -tespit edilebildiği kadarıyla Kuruldan resmî bir görüş alınmadan- teravihlerin 2'şer rekât olarak kılınması hakkında bir uygulamaya -31.05.2013 tarihli Genelge istisnadır. Burada iki rekâtta veya dört rekâtta bir selam denilmektedir.- gidilmiştir. Teravih namazının 2 rekâtta bir selam vererek kılınmasının faziletli olduğu hususuna Kurulun konu hakkındaki bilgilendirmesinde yer verilmiş olsa da (Din İşleri Yüksek Kurulu, Fetvalar, 199) Türkiye ve yakın çevresinde Hanefî mezhebine mensup olanların teravih namazlarını 4 rekâtta bir selamla eda ettikleri herkesin bildiği fiilî bir durumdur. Kurulun, söz konusu bilgilendirmesinde bu uygulamayı da dikkate alarak "dört rekâtta bir selam vererek kılmanın caiz olduğuna" işaret ettiği görülmektedir. Nitekim Enderun usulünde 4 rekâtta bir selam uygulaması ile
} 
Başkanlarının Kurulun önemine vurgu yaptıkları ${ }^{132}$ ve Başkanlar ve Başkanlığın, Din İşleri Yüksek Kurulunun karar, mütalaa, fetva ve görüşlerine önem verip dikkate aldıkları görülmektedir. Başkanların ve Başkanlığın, öteden beri ülkemiz ve yakın çevresinde cereyan eden farklı olaylar hakkında gerek teşkilatı gerek Devlet kurumlarını gerekse kamuoyunu Kurulun karar ve görüşlerinin yanı sıra yine Kurul tarafından düzenlenen uluslararası ya da ulusal kongreler, şurâlar ya da toplantıların sonuç bildirgeleriyle veya Kurulun hazırladığı raporlarla bilgilendirdiği bilinmektedir. Ayrıca Aile planlaması, başörtüsü ve Türkçe ibadet örneklerinde görüldüğü üzere Diyanet İşleri Başkanlarının sıcak gündem maddeleriyle alakalı Başkanlığa gelen konuları Din İşleri Yüksek Kuruluna havale edip Kurulun görüşüne dayanarak işlem yürütmüş olmaları önemle vurgulanmalıdır. Söz gelimi

hatimle teravih uygulamalarında her rekâtta 1 sayfa esasıyla $4 \times 5$ şeklinde her gün bir cüz okunması bu kabulün teravih kültürünün yerleşik bir uygulaması olduğunu teyit etmektedir. Cemaatle kılınan söz konusu teravihlerde imamın her 4 rekâtı ayrı bir makamla kıldırması, müezzinin imamın okuduğu makamdan bir ilahi (toplam 5) okuması, her 4 rekât ve sonrasında okunan ilahilerin genellikle belirlenmiş olan (meselâ bir uygulamaya göre 1. dört 1sfahan veya neva, 2. dört sabâ, 3. dört hüseynî, 4. dört eviç, 5 . dört acemaşiran) makamlarla okunup icrâ edilmesi konuyu açıkça teyit etmektedir. Nuri Özcan, "Kültür ve Geleneğimizde Teravih Namazı-Mûsiki İlişkisi", Din ve Hayat: İstanbul Müftülü̆ğü Dergisi 5 (2008), 6162; Fatih Koca, İslam Medeniyetinde Salâ ve Salavat Geleneği -Anadolu Örneği- (Ankara: Diyanet İşleri Başkanlığı Yayınları, 2. Baskı, 2017), 52-54.

Başkan Ali Erbaş, 2019, 2020 ve 2021 yıllarında verdiği müteaddid beyanlarda "sigara içmenin haram olduğunu" dile getirmiştir. Yukarıda bazı detaylarına değinilip tüp bebek örneğinde işaret edildiği üzere fıkıh ilminde içtihadın değişime imkân veren potansiyeli çerçevesinde Kurul bir konu hakkında verdiği bir karar ya da görüşünü yeni bilimsel veriler vb. ortaya çıkması durumunda değiştirip güncelleyebilmektedir. Aynı durum sigara içmenin hükmü konusunda da söz konusudur. Daha önceki fetvalarında sigara içmenin en azından "tahrimen mekruh" olduğunu belirten Kurul, konu hakkındaki gelişmelere bağlı olarak sigara ile ilgili gerek tahrimen mekruh gerek haram diyenlerin görüşlerini paylaştıktan sonra "caiz olmadığı" hükmünü vermektedir. https://kurul.diyanet.gov.tr/CevapAra/38295/sigara-icmenin-dini-hukmu-nedir-? (Erişim tarihi: 03.10.2021). Kurul sigara içmenin hükmü konusunda konu hakkında yaşanan ilmî gelişmeler ve tıbbî veriler bağlamında "tahrimen mekruh olduğu" şeklindeki görüşünü "câiz değildir" şeklinde değiştirmiş olsa da açıkça "haram" olduğunu söylememiştir.

132 Tayyar Altıkulaç, 9 Şubat 1978 tarihinde Başkan olarak göreve başladığında 8 yıldır seçim yapılamadı̆̆ 1 için teşkil edilemeyen Kurulun teşkili için hemen 2 Mart 1978 tarihinde seçim işlemlerini başlatmış, 17 Mart 1978 tarihinde yapılan Kurul seçimi sonrası göreve başlayan üyelerle 28 Nisan 1978 tarihinde yapılan ilk toplantıda söz konusu 8 yılı ülkenin dinî hayatı için "bunalım yılları” olarak nitelendirmiş, Kurulun işe başlamasıyla artık "kimsenin din konusunda aklına geldiği gibi konuşamayacağını, bu boşluğun Kurul tarafından doldurulacağını" ifade etmiştir. Tayyar Altıkulaç, “Din Şurası”, Diyanet Gazetesi 335 (15 Mayıs 1978), 15. Altıkulaç, Kurulun Başkanlığın “en yüksek karar ve danışma organı olması” hükmüne 2010 yılında getirilen "dinî konularda" sınırlamasının doğru olmadığını ifade etmekte, böylelikle Kurulun etkinlik ve itibarının zaafa uğratıldığını düşünmektedir. Altıkulaç, Zorlukları Aşarken, 1/271-272, 355-356. Başkan Ali Bardakoğlu, Kurulun Başkanlık, ülke ve İslâm dünyası için önemine vurgu yapmaktadır. Bardakoğlu, Din ve Diyanet, 2/82-91. Başkan Mehmet Görmez'in, Kurulun “Diyanet'in kendisi kadar önemli olduğunu, bu bağlamda zaman içerisinde devlet(erkini kullananlar)in dinî alanda özellikle diyanî ve teabbüdî alanlarda yapacağı bir takım yanlışları önleme konusunda çok büyük görevler üstlendiğini, ara ve zor dönemlerde dahi dinin hiçbir hükmünden taviz vermediğini, dinin sabitelerinden sapmadığını" ifade ettiği görülmektedir. https://www.youtube.com/watch?v=HrKvAzy7WKs. Başkan Ali Erbaş da “geçmişten günümüze Kurulun dinî hayatta milletin en güvenilir dayană̆ı olduğunu” vurgulamaktadır. https://diyanet.gov.tr/tr-TR/Kurumsal/Detay/29882/din-isleri-yuksek-kurulu-yeni-baskanini-secti. 
Kurul 1997 yılında aldığı “Türkçe ibadet" hususundaki kararında metne alıp atıfta bulunduğu üzere; yukarıda sözü edilen 1926 yılında cuma namazında Kur'an-1 Kerim'in Türkçe tercümesini okuyan İstanbul Göztepe Camii İmam-Hatibi Cemal Efendi Diyanet İşleri Reisi Rifat Börekçi imzasıyla Müşavere Hey'eti kararına istinaden görevden alınmıştır. ${ }^{133}$ İşaret edilen hususlar ve benzerleri Diyanet İşleri Başkanlığının dinî söylemi açısından Din İşleri Yüksek Kurulunun mutlaka dikkate alınması gerektiği ortaya koymaktadır.

\section{Diyanet Gazetesi ve Diyanet Aylık Dergi'de Başyazılar}

Diyanet İşleri Başkanlığı, Kanunun yüklediği “din konusunda toplumu aydınlatma" görevini, hutbe, vaaz, dinî soruları cevaplandırma, cami dersleri, seminerler, konferanslar vb. yanı sıra kurulduğu yıllardan bu günlere basılı, süreli yayınlar, takvim yazıları, televizyon ve radyo programları gibi yürüttüğü yayın faaliyetleri ile yerine getirmektedir. ${ }^{134} 1954$ yılında Reislik Mecmuası ile başlayıp 1956 yılında yayımlanan ve İlmi Dergi ismiyle bilinen derginin ilk sayısı olarak kabul edilen "Diyanet İşleri Reisliği Mecmuası Ramazan Nüshası" ile sürdürülen Başkanlığın süreli yayın faaliyeti 1961 yılından itibaren daha sistematik bir hale kavuşarak bugünlere kadar gelmiştir. ${ }^{135}$ Bugün itibariyle Başkanlık süreli yayın olarak Diyanet Aylık Dergi, Aile Dergisi, Cim Dergisi, Çocuk Dergisi, İlmi Dergi ve Arapça İlmi Dergi, Arapça Kalem Dergisi, Arapça Çocuk Dergisi Nuceym'i neşretmektedir. ${ }^{136}$

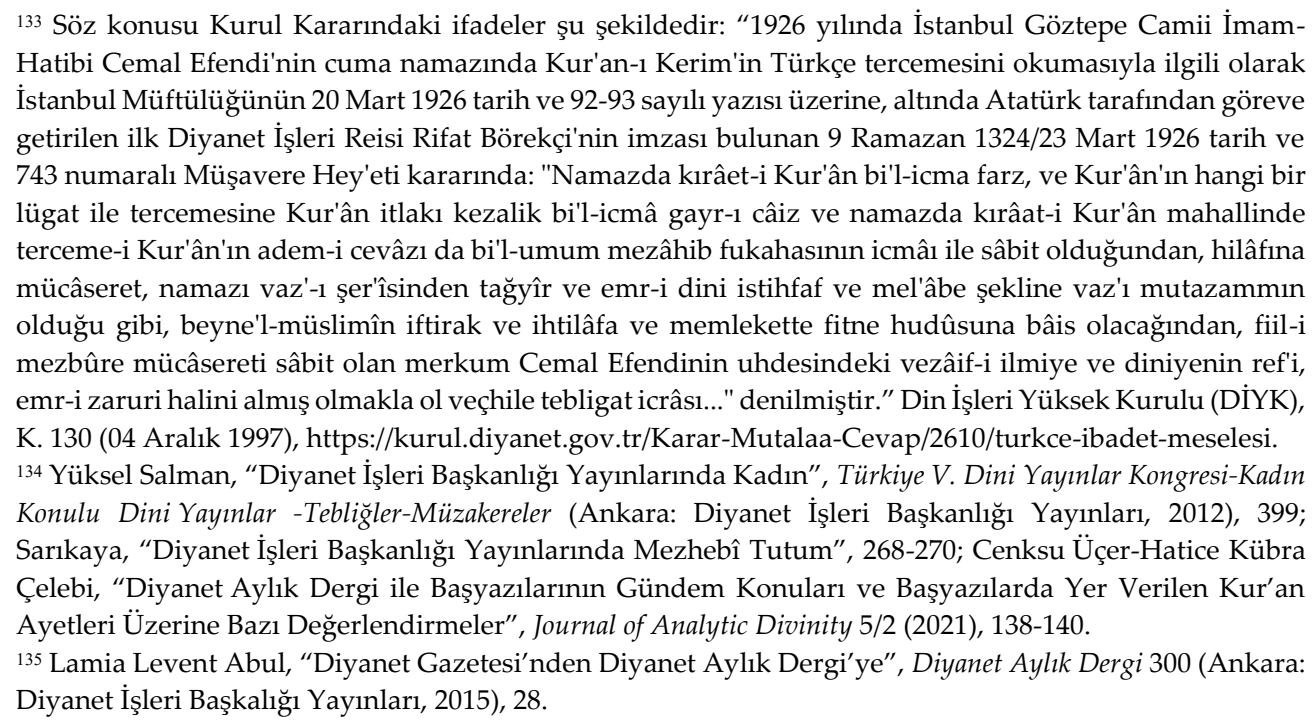

136 DỉB, Diyanet İşleri Başkanlığı, "Dini Yayınlar Genel Müdürlüğü", https://dergi.diyanet.gov.tr/indexarsiv.php. Başkanlık geçmişte Haber Bülteni, Diyanet Avrupa, Çocuk Ek, Aile Ek gibi günümüzde devam etmeyen süreli yayınları da neşretmiştir. Faruk Görgülü, "Dinî Dergicilik ve Süreli Yayınlarımız", Diyanet Aylık Dergi 300 (Ankara: Diyanet İşleri Başkalığı Yayınları, 2015), 24-26. 
Başkanlığın süreli yayınları arasında önemli bir yer tutan yayını şüphesiz bugün itibariyle Diyanet Aylık Dergi adıyla neşrettiği dergidir. Başkanlığın bu süreli yayınına dair faaliyeti 22 Kasım 1968'de yayımlanmaya başlayan ve 15 günde bir neşredilen "Diyanet Gazetesi" ile başlamıştır. Başkanlık Diyanet Gazetesi'ni Kasım 1968'den Aralık 1990'a kadar farklı format ve ebatlarda yayımlamıştır. Başkanlık Aralık 1990'da neşredilen 382. (son) sayıdan sonra Ocak 1991'de Diyanet Gazetesi'nde gerek isim gerek şekil gerekse muhteva olarak bir değişikliğe gitmiştir. $\mathrm{Bu}$ değişikliğe göre Diyanet Gazetesi, "Diyanet Aylık Dergi" ismiyle aylık yayımlanan bir dergiye dönüştürülmüştür. ${ }^{137}$ Ağustos 2021 tarihi itibariyle 368. sayısı yayımlanmış olan Diyanet Aylık Dergi, "dinin sahih bilgisi ve ona dayalı kültür, sanat ve edebiyat birikimini okurlarıyla paylaşmayı amaçlayan; bu itibarla toplumda yaşanan dinî ve sosyo-kültürel gelişmeleri dikkate alarak farklı alanlarda aktüel gündemlerle okurunun karşısına çıan" bir dergidir. ${ }^{138}$

Başkanlığın en üst amiri olan Diyanet İşleri Başkanı, 633 sayılı Teşkilat Kanununda "din hizmetlerinin etkin ve verimli sunulması için gerekli tedbirleri almak, strateji, hedef ve performans kriterlerini belirleyip uygulanmasın temin etmek ve Başkanlığın görev alanına giren konularda meydana gelen gelişmelere ve ihtiyaçlara göre birimlere görev vermek"le yükümlü tutulmuştur. ${ }^{139}$ Başkanlığın topluma vermek istediği mesajı en güçlü şekilde Diyanet İşleri Başkanının dilinden vereceği aşikârdır. Nitekim Diyanet İşleri Başkanları, teşkilatı, toplumu ve dünya kamuoyunu çeşitli yazılar, basın açıklamaları, röportajlar, bildiriler, köşe yazıları, özel gün ve geceler ya da olaylara yönelik yayımladıkları mesajlar, ulusaluluslararası programların açış konuşmaları, ulusal-uluslararası konferanslar, sosyal medya platformları gibi farklı yollarla bilgilendirmişlerdir. ${ }^{140}$

Diyanet Gazetesi ve Diyanet Aylık Dergi'de ilk sayıdan itibaren Diyanet İşleri Başkanlarına ait yazılara yer verilmiştir. Başmakale ya da Başyazı ${ }^{141}$ adıyla yer alan bu yazıların, söz konusu süreli yayınların önemli kısımlarından olduğu muhakkaktır. Bu itibarla Diyanet İşleri Başkanlığının dinî söylemi hakkındaki bu

\footnotetext{
${ }^{137}$ Kuruluşundan Günümüze Diyanet İşleri Başkanlığı, 709-710; Abul, “Diyanet Gazetesi'nden Diyanet Aylık Dergi'ye", 30-31.

${ }^{138}$ Diyanet Gazetesinden Diyanet Aylık Dergi' de ele alınan konular ve ortaya koyulan yaklaşım hakkında bkz. Mustafa Bayar, "Yaygın Din Eğitimi Bağlamında Diyanet İşleri Başkanlığı'nın Süreli Yayın Hizmetleri", Uluslararası Sosyal Araştırmalar Dergisi 8/36 (2015), 457; Abul, "Diyanet Gazetesi'nden Diyanet Aylık Dergi'ye", 30-33; Üçer-Çelebi, "Diyanet Aylık Dergi ile Başyazılarının Gündem Konular1", 141-145.

139633 Sayılı Diyanet İşleri Başkanlığı Kuruluş ve Görevleri Hakkında Kanun, m. 3.

${ }^{140}$ Diyanet İşleri Başkanlarından bazılarının söz konusu bilgilendirmeleri yayımlanmıştır. Altıkulaç, Zorlukları Aşarken; Diyanet İşleri Başkanlığı (DİB), Diyanet İşleri Başkanı Mehmet Nuri Yılmaz'ın Röportajları, Basın Açıklamaları, Sempozyum ve Panel Konuşmaları, Protokol Konuşmaları, Konferans ve Makaleleri, haz. Ali Yıldırım, Yusuf Ziya Yağcıŏglu (Ankara: Diyanet İşleri Başkanlığı Yayınları, 1995); Bardakoğlu, 21. Yüzyıl Türkiye'sinde Din ve Diyanet.

${ }^{141}$ Bayar, "Yaygın Din Eğitimi Bağlamında Diyanet İşleri Başkanlığı'nın Süreli Yayın Hizmetleri", 457. Bu meyanda bazen Diyanet İşleri Başkan Vekili ve Yardımcılarının da yazı kaleme aldıkları görülmektedir.
} 
çalışmamız, yukarıda işaret edildiği üzere her ne kadar bu konudaki bir çalışma başta Din İşleri Yüksek Kurulunun kararları, mütalaaları, görüşleri ya da faaliyetleri olmak üzere değişik birimler ile hutbeler, takvim yazıları vb. farklı hizmetlerin ayrı ayrı ele alınıp incelenmesini gerektiren bir özelliğe sahipse de, Başkanlığın topluma vermek istediği en güçlü bilgilendirme ve mesajı Diyanet İşleri Başkanı aracılığıyla vereceğinden hareketle Diyanet Gazetesi ve Diyanet Aylık Dergi'de yer alan ve Başkanlara ait Başmakale ve Başyazı'lar üzerinden konuyu değerlendirmektedir.

Öncelikle ifade edilmelidir ki Diyanet Gazetesi'nin her sayısında Başyazı yer almamaktadır. Bu itibarla neşredilen Gazete sayısı ile Başyazı sayısı farklılık göstermektedir. 1968 yılında yayın hayatına başlayan ve 1990 yılına kadar yayımlanan Diyanet Gazetesi 382 sayı olarak neşredilmiş, 382 sayının 277 sayısında Başyazı yer almıştır. Söz gelimi Lütfi Doğan'ın görev süresinde 1968 Kasım'dan 1972 Eylül'e yayımlanan 50 Diyanet Gazetesi'nde 47 Başyazı kaleme alınmış, 3 sayı Başyazı olmadan neşredilmiştir. Bu bağlamda Diyanet Gazetesi'nde yer alan 1972 Eylül'den 1976 Ağustos'a (51-146 arası yayımlanmış 92 sayıda) 85 Başyazı Dr. Lütfi Doğan, 1976 Ağustos'tan 1978 Şubat'a (147-182 arası yayımlanmış 36 sayıda) 36 Başyazı Doç. Dr. Süleyman Ateş, 1978 Şubat'tan 1978 Nisan'a (183-187 arası yayımlanmış 5 sayıda) 5 Başyazı Tayyar Altıkulaç, 1978 Mayıs'tan 1988 Mart'a (188349 arası yayımlanmış 150 sayıda) 2 Başyazı Başkan Tayyar Altıkulaç, 83 Başyazı Başkan Yardımcıları Halil Sevgin (9 adet), Hamdi Mert (36 adet), Lütfi Şentürk (15 adet), Niyazi Baloğlu (11 adet), Ahmet Gürtaş (3 adet) ve Halit Güler (9 adet) tarafından kaleme alınmış, 6 Başyazı ise Diyanet adıyla neşredilmiştir. 1989 Ocak'tan 1990 Aralık'a (359-382 arası yayımlanmış 24 sayıda) 6 Başyazı Başkan Prof. Dr. M. Said Yazıcıoğlu, 5 Başyazı Başkan Yardımcıları Seyfeddin Yazıcı (2 adet), Hamdi Mert (2 adet), Mushafları İnceleme Kurulu Başkanı Ahmet Okutan (1 adet) tarafından kaleme alınmış, 1 sayı ise isimsiz olarak yayımlanmıştır.

Diyanet Aylık Dergi'de ise 1991 Ocak'tan 1992 Ocak'a (1-13) 13 sayının Başyazıları Prof. Dr. Mustafa Said Yazıcıŏ̆lu, 1992 Şubat'tan 2003 Mart'a (14-147) 135 sayının Başyazıları Mehmet Nuri Yılmaz, 2003 Nisan'dan 2003 Haziran'a (148150) 3 sayının Başyazıları Başkan Vekili Rıdvan Çakır, 2003 Temmuz'dan 2010 Kasım'a (151-239) 90 sayının Başyazıları Prof. Dr. Ali Bardakoğlu, 2017 Ekim'den 2021 Ağustos'a (240-319) 81 sayının Başyazıları Prof. Dr. Mehmet Görmez, 2017 Ağustos'tan 2017 Eylül'e (320-321) 2 sayının Başyazıları Başkan Vekili Dr. Ekrem Keleş, 2017 Ekim'den 2021 Ağustos'a (322-368) 48 sayının Başyazıları Prof. Dr. Ali Erbaş'a aittir.

\section{Başyazılardaki Çerçeve}

Gerek Diyanet Gazetesi gerek Diyanet Aylık Dergi'deki Başyazılar bizzat Diyanet İşleri Başkanının doğrudan gerek teşkilata gerek kamuoyuna bilgilendirme ve mesajını içermektedir. Diyanet Gazetesi'nin 22 Kasım 1968 yılının Ramazan ayına denk gelen ilk sayısında dönemin Diyanet İşleri Başkanı Lütfi Doğan bir Başmakale 
kaleme alarak "dinî ve ahlakî esasların en iyi ve en geniş çapta halka ulaştırmanın yolunun neşriyattan geçtiğini" belirtip, o zamana kadar din görevlileri aracillğ̆yla yapılan bu hizmetin bundan sonra yayın yoluyla da yapılacağını; zira "cemiyetin düşünce seyrinin ancak matbuatla yükseltileceğini" ifade etmiş ve Gazete'nin gayesini şöylece dile getirmiştir: "Dinimizin iman, ibadet ve ahlak düsturlarını, helal ve haramlarını, bütün buyruklarını ve yasaklarını, yurdumuzun en ücra köşelerinde yaşayan vatandaşlarımıza kadar duyurmak, maddî ve manevî yönden faydalı olmak maksadıyla, on beş günde bir ve on altı sahife olarak yayınlanması kararlaştırılan Diyanet Gazetesi bunu gerçekleştirmek üzere çıkacaktır." 1421991 yılının ocak ayında Diyanet Gazetesi'nden Diyanet Aylık Dergi'ye geçiş sürecinde Diyanet Aylık Dergi'nin 1. sayısında -döneminde Kurum personelinin eğitim düzeyinin yükseltilmesini önemseyip İlahiyat ve Üniversitelerle işbirliği hususunu ön planda tutan- Diyanet İşleri Başkanı Prof. Dr. M. Said Yazıcıŏglu143 da "bütünleştirici yayıncılığı esas alan mevkute" olarak bu yeni dergide "halkın ihtiyaç duyduğu konuların işleneceği ve böylece kamuoyunun beklentilerine cevap verileceğini" dile getirmiştir. ${ }^{144}$

Diyanet İşleri Başkanlarının Diyanet Gazetesi ve Diyanet Aylık Dergi'nin ilk sayılarında dile getirdikleri söz konusu amaç ve muhtevanın hem Gazete ve Dergi'nin hem Başyazıların ele aldıkları konu ve gündemleri göz önünde bulundurulduğunda başlangıçtan bugüne kadar bütün Başkanlar tarafından ortak bir tavırla önemle üzerinde durulduğu anlaşılmaktadır.

\subsection{Diyanet Gazetesi Başyazıları}

Diyanet Gazetesi Başyazılarında ele alınan konuların, daha önce Diyanet Aylık Dergi ve Başyazıları hakkında yapılan çalışmadaki esaslar dikkate alınarak, Kanunun Başkanlığa yüklediği görevler bağlamında tasnif edilerek incelenmesinin Başkanlığın dinî söyleminin ana çerçevesini ortaya koymak açısından yerinde olacağ 1 değerlendirilmektedir. Bu itibarla konu Diyanet Gazetesi ve Diyanet Aylık Dergi Başyazı gündem konularının daha çok Kanunun süreç içerisinde Başkanlığa verdiği yükümlülüklere göre iman esasları ve inanç konuları, ibadetler, ahlak -her ne kadar dinî sosyo-kültürel ve aktüel hayatla ilgili konular ahlak genel başlığında yer alabilecek mahiyette olsa da doğrudan ahlak kelimesi kullanılan yazılar olması hasebiyle önemine binaen burada ayrıca değerlendirilmiştir.- birlik ve beraberlik,

\footnotetext{
${ }^{142}$ Lütfi Doğan, “Başlarken”, Diyanet Gazetesi 1 (1968), 1, 16; Abul, “Diyanet Gazetesi'nden Diyanet Aylık Dergi'ye", 30.

143 Yazıcıŏglu, Anılar, 157-171. Başkan Yazıcıŏglu ilk defa Din İşleri Yüksek Kurulu üyeliklerine üniversiteden (ilahiyat fakültesi) seçime girmeksizin Başkanın doğrudan teklifi ile 4 adet öğretim üyesi atanmasını sağlamış ve bu hususu konu hakkında çıkarılan KHK ile mevzuata bağlamıştır. Yazıcıŏglu, Anilar, 286-289.

${ }^{144}$ M. Said Yazıcıŏ̆lu, “Başyazı”, Diyanet Aylık Dergi 1 (1991), I; Üçer-Çelebi, “Diyanet Aylık Dergi ile Başyazılarının Gündem Konuları", 142-143.
} 
dinî sosyo-kültürel ve aktüel hayat - Bu başlık altında yer verilen konular da aslında ahlak genel başlığında yer alabilecek mahiyettedir, ancak konumuz açısından önemli görülerek ayrı başlık altında ele alınmıştır.- şeklinde tasnif edilerek işlenmiştir. ${ }^{145}$

1968 yılının Kasım ayındaki ilk sayısıyla yayın hayatına başlayan ve 1990 yılının Aralık ayında 382. sayısıyla 22 yıllık yayın hayatına son verip bayrağı Diyanet Aylık Dergi'ye devreden Diyanet Gazetesi'nin 277 sayısında Başyazının yer aldığ görülmektedir. Diyanet Gazetesi'nde kimi Başkanlar kimi Başkan Yardımcıları tarafından; kimi Başkanlık adıyla kimi isimsiz olarak kaleme alınan Başyazıların konulara göre rakamsal dağılımına göz atıldığında şu şekilde bir tablo ortaya çıkmaktadır:

Tablo 1: Diyanet Gazetesi Başyazıların Konulara Göre Rakamsal Dağılımı

\begin{tabular}{|c|c|c|c|c|c|}
\hline $\begin{array}{c}\text { Diyanet İşleri } \\
\text { Başkanları }\end{array}$ & $\begin{array}{c}\text { İman } \\
\text { Esasları } \\
\text { ve İnanç } \\
\text { Konuları } \\
\end{array}$ & $\begin{array}{c}\text { İbadet } \\
\text { Hayatı ve } \\
\text { İbadetler }\end{array}$ & Ahlak & $\begin{array}{l}\text { Birlik ve } \\
\text { Beraberlik }\end{array}$ & $\begin{array}{c}\text { Dinî Sosyo- } \\
\text { Külttürel } \\
\text { Hayat }\end{array}$ \\
\hline Lütfi Doğan & 2 & 4 & 1 & 6 & 34 \\
\hline Dr. Lütfi Doğan & 1 & 6 & 1 & 6 & 71 \\
\hline Süleyman Ateş & - & 1 & 1 & - & 34 \\
\hline Tayyar Altıkulaç & 1 & - & - & - & 7 \\
\hline M. Said Yazıcıŏglu & - & - & - & 1 & 5 \\
\hline $\begin{array}{c}\text { Diyanet İşleri } \\
\text { Başkan } \\
\text { Yardımcıları vd. }\end{array}$ & $\begin{array}{c}\text { İman } \\
\text { Esasları } \\
\text { ve İnanç } \\
\text { Konuları }\end{array}$ & $\begin{array}{c}\text { İbadet } \\
\text { Hayatı ve } \\
\text { İbadetler }\end{array}$ & Ahlak & $\begin{array}{l}\text { Birlik ve } \\
\text { Beraberlik }\end{array}$ & $\begin{array}{c}\text { Dinî Sosyo- } \\
\text { Kültürel } \\
\text { Hayat }\end{array}$ \\
\hline Lütfi Şentürk & - & 2 & 1 & 1 & 11 \\
\hline Halil Sevgin & - & 2 & - & - & 7 \\
\hline Halit Güler & - & 3 & - & - & 6 \\
\hline Hamdi Mert & - & - & 1 & 3 & 34 \\
\hline Niyazi Baloğlu & - & - & - & 1 & 10 \\
\hline Ahmet Gürtaş & & & & & 3 \\
\hline Seyfettin Yazıcı & - & - & - & - & 2 \\
\hline $\begin{array}{l}\text { Ahmet Okutan } \\
\text { (Mus. İnc. Krl. Bşk.) }\end{array}$ & - & - & - & - & 1 \\
\hline Diyanet & - & - & - & - & 6 \\
\hline İsimsiz & - & - & - & - & 1 \\
\hline Toplam & 4 & 18 & 5 & 18 & 232 \\
\hline
\end{tabular}

Diyanet Gazetesi Başyazılarının 4 adet $(\% 1,5)$ iman esasları ve inanç konuları, 18 adet $(\% 6,5)$ ibadetler, 5 adet $(\% 1,8)$ ahlak, 18 adet $(\% 6,5)$ birlik ve beraberlik, 232 adet $(\% 83,7)$ de dinî sosyo-kültürel hayatla ilgili olduğu görülmektedir.

145 Üçer-Çelebi, “Diyanet Aylık Dergi ile Başyazılarının Gündem Konuları”, 136-137. 
Şekil 1. Diyanet Gazetesi Başyazılarının Ana Konulara Göre Yüzdelik Dağılımı

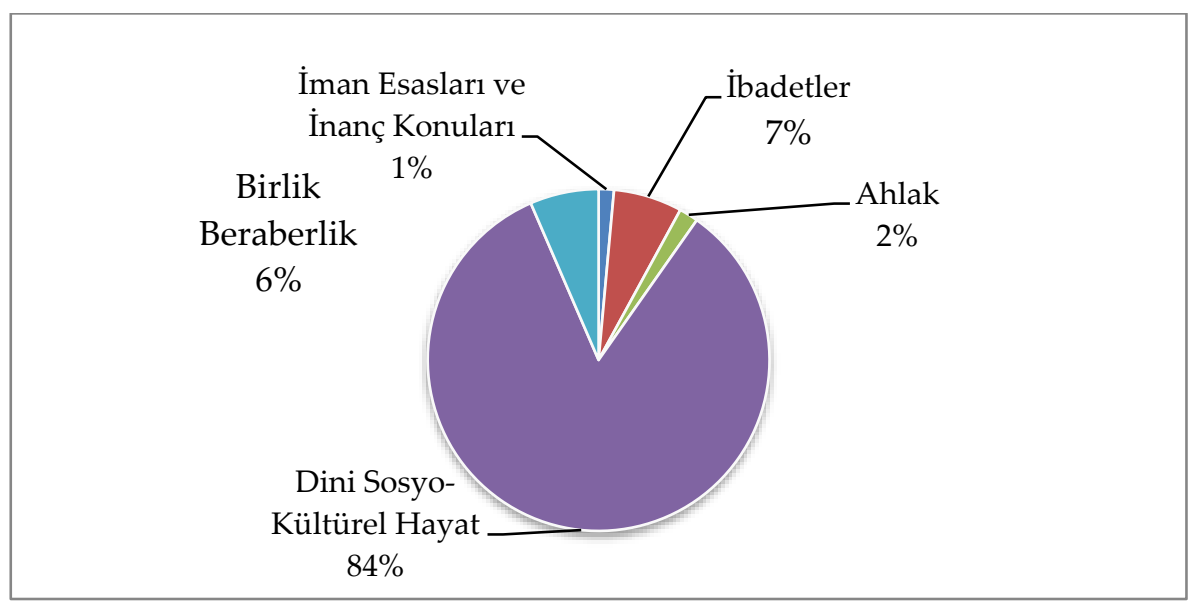

İman esasları ve inanç konuları, ibadetler, ahlak, birlik ve beraberlik, dinî sosyokültürel hayatla ilgili hususlarda Başyazılarda ele alınan konuların detaylarının ortaya konulması Başkanlığın dinî söyleminin görülmesi adına faydalı olacaktır. Bu itibarla yazılan yazılardan bazı seçme başlıklar aşağıda tablo halinde verilmiştir. Burada tablonun dinî sosyo-kültürel hayat ve aktüel konuların biraz daha alt kategorilere ayrılarak oluşturulduğu ifade edilmelidir. Bu bağlamda dinî sosyokültürel hayat ve aktüel konuların Hz. Peygamber; Ramazan ve toplumsal yansımaları; cami ve din görevlileri; israf, saygı, sevgi, komşuluk, doğruluk, hicret vb. farklı dinî sosyo-kültürel konular; Meşhed, Yugoslavya, Papa ziyareti, İnsan Hakları Beyannamesi vb. aktüel konular; ilim ve eğitim; çevre; helal duyarlılığı; sağlık, millî ve dinî gün ve geceler ve din kongreleri gibi alt başlıklar halinde incelemeye tabi tutulmuştur.

\subsection{1. İman Esasları ve İnanç Konuları}

Tablo 2. İman Esasları ve İnanç Konularında Diyanet Gazetesi Başyazı Gündemleri

\begin{tabular}{|l|l|l|l|l|l|l|l|}
\hline Y1l & Ay & $\begin{array}{l}\text { Başyazı } \\
\text { Gündemi }\end{array}$ & Yazan & Y1l & Ay & $\begin{array}{l}\text { Başyazı } \\
\text { Gündemi }\end{array}$ & Yazan \\
\hline 1968 & Kasım & Başlarken & $\begin{array}{l}\text { L. } \\
\text { Doğan }\end{array}$ & 1976 & Aralı & $\begin{array}{l}\text { Kaderin } \\
\text { Dışında } \\
\text { Kalan Hiçbir } \\
\text { Şey Yoktur }\end{array}$ & S. Ateş \\
\hline 1972 & Mayıs & $\begin{array}{l}\text { İnancın } \\
\text { Verdiği } \\
\text { Huzur }\end{array}$ & $\begin{array}{l}\text { L. Doğan } \\
\text { Doun }\end{array}$ & 1978 & Nisan & $\begin{array}{l}\text { Tevhidin } \\
\text { Neresindeyiz }\end{array}$ & $\begin{array}{l}\text { T. } \\
\text { Altıkulaç }\end{array}$ \\
\hline
\end{tabular}




\subsection{2. İbadetler}

Tablo 3. İbadetler Konusunda Diyanet Gazetesi Başyazı Gündemleri

\begin{tabular}{|l|l|l|l|l|l|l|l|}
\hline Y11 & Ay & $\begin{array}{l}\text { Başyazı } \\
\text { Gündemi }\end{array}$ & Yazan & Yıl & Ay & $\begin{array}{l}\text { Başyazı } \\
\text { Gündemi }\end{array}$ & Yazan \\
\hline 1970 & Kasım & $\begin{array}{l}\text { Ramazan'a } \\
\text { Girerken } \\
\text { Ramazan ve } \\
\text { Yansımaları }\end{array}$ & $\begin{array}{l}\text { L. } \\
\text { Doğan }\end{array}$ & 1975 & Temmuz & Dua & $\begin{array}{l}\text { Dr. L. } \\
\text { Doğan }\end{array}$ \\
\hline 1970 & Aralık & $\begin{array}{l}\text { İçtimai } \\
\text { Yardımlaşmanın } \\
\text { En Adilini } \\
\text { İslamiyet } \\
\text { Kurmuştur. }\end{array}$ & $\begin{array}{l}\text { L. } \\
\text { Doğan }\end{array}$ & 1977 & Ağustos & $\begin{array}{l}\text { Oruçla İlgili } \\
\text { Bazı Özel } \\
\text { Meseleler }\end{array}$ & S. Ateş \\
\hline 1972 & Ocak & Hac Farizası & $\begin{array}{l}\text { L. } \\
\text { Doğan }\end{array}$ & 1978 & Eylül & Hac & $\begin{array}{l}\text { L. } \\
\text { Şentürk }\end{array}$ \\
\hline 1972 & Eylül & Mücahede Azmi & $\begin{array}{l}\text { L. } \\
\text { Doğan }\end{array}$ & 1979 & Eylül & $\begin{array}{l}\text { Namaz ve } \\
\text { Namazın } \\
\text { Yüce Anlamı }\end{array}$ & $\begin{array}{l}\text { H. } \\
\text { Sevgin }\end{array}$ \\
\hline 1973 & Aralık & $\begin{array}{l}\text { Hac Mevsimi } \\
\text { Başladı }\end{array}$ & $\begin{array}{l}\text { Dr. L. } \\
\text { Doğan }\end{array}$ & 1979 & Ekim & $\begin{array}{l}\text { Bir Bayram } \\
\text { Namazı ve } \\
\text { Hatırlattıları }\end{array}$ & $\begin{array}{l}\text { H. } \\
\text { Sevgin }\end{array}$ \\
\hline 1973 & Aralı & Kurban & $\begin{array}{l}\text { Dr. L. } \\
\text { Doğan }\end{array}$ & 1979 & Ekim & Hac & $\begin{array}{l}\text { L. } \\
\text { Şentürk }\end{array}$ \\
\hline 1974 & Şubat & Hac Dönüşü & $\begin{array}{l}\text { Dr. L. } \\
\text { Doğan }\end{array}$ & 1983 & Haziran & $\begin{array}{l}\text { Oruç Allah } \\
\text { İçindir }\end{array}$ & H. Güler \\
\hline 1974 & Aralı & Hac ve Kurban & $\begin{array}{l}\text { Dr. L. } \\
\text { Doğan }\end{array}$ & 1986 & Mayıs & $\begin{array}{l}\text { Kur'an ve } \\
\text { Ramazan }\end{array}$ & H. Güler \\
\hline 1975 & Ocak & $\begin{array}{l}\text { Kurban } \\
\text { Hakkığa } \\
\text { Aç1klama }\end{array}$ & 1986 & Haziran & Oruttuk & H. Güler \\
\hline
\end{tabular}

\subsubsection{Ahlak}

Tablo 4. Ahlak Konusunda Diyanet Gazetesi Başyazı Gündemleri

\begin{tabular}{|l|l|l|l|l|l|l|l|}
\hline Yıl & Ay & $\begin{array}{l}\text { Başyazı } \\
\text { Gündemi }\end{array}$ & Yazan & Y1l & Ay & $\begin{array}{l}\text { Başyazı } \\
\text { Gündemi }\end{array}$ & Yazan \\
\hline 1972 & Haziran & $\begin{array}{l}\text { Utanma } \\
\text { Duygusu } \\
\text { İmandandır }\end{array}$ & L. Doğan & 1978 & Ekim & $\begin{array}{l}\text { İman ile Ahlak } \\
\text { Arasındaki } \\
\text { Münasebet }\end{array}$ & $\begin{array}{l}\text { L. } \\
\text { Şentürk }\end{array}$ \\
\hline 1974 & Mart & Ahlak & L. Doğan & 1979 & Şubat & Meslek Ahlakı & H. Mert \\
\hline 1976 & Ekim & $\begin{array}{l}\text { İnsan } \\
\text { İhtiraslarını } \\
\text { Frenlemelidir }\end{array}$ & S. Ateş & & & & \\
\hline
\end{tabular}




\subsubsection{Birlik ve Beraberlik}

Tablo 5. Birlik ve Beraberlik Konusunda Diyanet Gazetesi Başyazı Gündemleri

\begin{tabular}{|c|c|c|c|c|c|c|c|}
\hline Yil & Ay & $\begin{array}{l}\text { Başyazı } \\
\text { Gündemi }\end{array}$ & Yazan & Yil & Ay & $\begin{array}{l}\text { Başyazı } \\
\text { Gündemi }\end{array}$ & Yazan \\
\hline 1969 & Ocak & $\begin{array}{l}\text { Bayram ve } \\
\text { Hikmetleri }\end{array}$ & $\begin{array}{l}\text { L. } \\
\text { Doğan }\end{array}$ & 1976 & Nisan & Yurt Sevgisi & $\begin{array}{l}\text { Dr. L. } \\
\text { Doğan }\end{array}$ \\
\hline 1970 & Kasım & $\begin{array}{l}\text { Müminler } \\
\text { Ancak } \\
\text { Kardeştirler }\end{array}$ & $\begin{array}{l}\text { L. } \\
\text { Doğan }\end{array}$ & 1976 & Mayıs & Hidrellez & $\begin{array}{l}\text { Dr. L. } \\
\text { Doğan }\end{array}$ \\
\hline 1971 & Mart & $\begin{array}{l}\text { Birlik ve } \\
\text { Yardımlaşma } \\
\text { Her İyiliğin } \\
\text { Esasıdır. }\end{array}$ & $\begin{array}{l}\text { L. } \\
\text { Doğan }\end{array}$ & 1976 & Haziran & $\begin{array}{l}\text { İstanbul'un } \\
\text { Fethi }\end{array}$ & $\begin{array}{l}\text { Dr. L. } \\
\text { Doğan }\end{array}$ \\
\hline 1971 & Mart & $\begin{array}{l}\text { Kardeşlik } \\
\text { Ruhu }\end{array}$ & $\begin{array}{l}\text { L. } \\
\text { Doğan }\end{array}$ & 1979 & Ağustos & $\begin{array}{l}\text { Sevgi ve } \\
\text { Sayg1 }\end{array}$ & $\begin{array}{l}\text { L. } \\
\text { Şentürk }\end{array}$ \\
\hline 1971 & Ağustos & $\begin{array}{l}\text { Cemiyetler } \\
\text { Zafere Birlik, } \\
\text { Sadakat ve } \\
\text { Çalış̧makla } \\
\text { Ulaşır }\end{array}$ & $\begin{array}{l}\text { L. } \\
\text { Doğan }\end{array}$ & 1980 & Mart & $\begin{array}{l}\text { Tek Çıkar } \\
\text { Yol } \\
\text { Bütünleşmek }\end{array}$ & H. Mert \\
\hline 1972 & Haziran & $\begin{array}{l}\text { Birlik ve } \\
\text { Beraberlik } \\
\text { Ruhu } \\
\text { Yükselmenin } \\
\text { Teminatıdır }\end{array}$ & $\begin{array}{l}\text { L. } \\
\text { Doğan }\end{array}$ & 1980 & Mart & $\begin{array}{l}\text { Çanakkale'yi } \\
\text { Anlamak }\end{array}$ & H. Mert \\
\hline 1973 & Mart & $\begin{array}{l}\text { Çanakkale } \\
\text { Zaferi }\end{array}$ & $\begin{array}{l}\text { Dr. L. } \\
\text { Doğan }\end{array}$ & 1980 & Mayıs & $\begin{array}{l}\text { İstanbul'un } \\
\text { Fethi ve } \\
\text { Dünya } \\
\text { Üzerindeki } \\
\text { Etkileri }\end{array}$ & $\begin{array}{l}\text { N. } \\
\text { Baloğlu }\end{array}$ \\
\hline 1973 & Ağustos & Zaferler Ayı & $\begin{array}{l}\text { Dr. L. } \\
\text { Doğan }\end{array}$ & 1981 & Ağustos & $\begin{array}{l}\text { Malazgirt'ten } \\
\text { Büyük } \\
\text { Taarruz'a } \\
\text { Zaferlerimiz } \\
\text { ve Sonrası }\end{array}$ & H. Mert \\
\hline 1975 & Ağustos & Birlik Nimeti & $\begin{array}{l}\text { Dr. L. } \\
\text { Doğan }\end{array}$ & 1990 & Mart & Birlik Ruhu & Diyanet \\
\hline
\end{tabular}




\subsubsection{Dinî Sosyo-Kültürel Hayat}

\subsubsection{Hz. Peygamber}

Tablo 6. Hz. Peygamber Konusunda Diyanet Gazetesi Başyazı Gündemleri

\begin{tabular}{|c|c|c|c|c|c|c|c|}
\hline Yil & Ay & $\begin{array}{l}\text { Başyazı } \\
\text { Gündemi }\end{array}$ & Yazan & Yil & Ay & $\begin{array}{l}\text { Başyazı } \\
\text { Gündemi }\end{array}$ & Yazan \\
\hline 1972 & Nisan & $\begin{array}{l}\text { Mevlid Kandili } \\
\text { Münasebetiyle }\end{array}$ & $\begin{array}{l}\text { L. } \\
\text { Doğan }\end{array}$ & 1976 & Mart & $\begin{array}{l}\text { Sevgili } \\
\text { Peygamberimiz }\end{array}$ & $\begin{array}{l}\text { Dr. L. } \\
\text { Doğan }\end{array}$ \\
\hline 1973 & Nisan & $\begin{array}{l}\text { Salat, Selam } \\
\text { Sana Ya } \\
\text { Resûlallah }\end{array}$ & $\begin{array}{l}\text { Dr. L. } \\
\text { Doğan }\end{array}$ & 1977 & Ocak & $\begin{array}{l}\text { Dışarıya } \\
\text { Açılmalıyız }\end{array}$ & S. Ateş \\
\hline 1974 & Nisan & Mevlid Kandili & $\begin{array}{l}\text { Dr. L. } \\
\text { Doğan }\end{array}$ & 1978 & Mart & Mevlid Kandili & T.Altıkulaç \\
\hline 1975 & Mart & $\begin{array}{l}\text { Peygamberimizi } \\
\text { Örnek Almak, } \\
\text { İnsanlara Örnek } \\
\text { Olmak }\end{array}$ & $\begin{array}{l}\text { Dr. L. } \\
\text { Doğan }\end{array}$ & 1979 & Şubat & Mevlid & L. Şentürk \\
\hline 1975 & Nisan & $\begin{array}{l}\text { Peygamberimiz } \\
\text { ve Çocuk } \\
\text { Sevgisi }\end{array}$ & $\begin{array}{l}\text { Dr. L. } \\
\text { Doğan }\end{array}$ & & & & \\
\hline
\end{tabular}

\subsubsection{Ramazan ve Toplumsal Yansımaları}

Tablo 7. Ramazan ve Toplumsal Yansımaları Konusunda Diyanet Gazetesi Başyazı Gündemleri

\begin{tabular}{|c|c|c|c|c|c|c|c|}
\hline Y1l & Ay & $\begin{array}{l}\text { Başyazı } \\
\text { Gündemi }\end{array}$ & Yazan & Y1l & Ay & $\begin{array}{l}\text { Başyazı } \\
\text { Gündemi }\end{array}$ & Yazan \\
\hline 1970 & Kasım & $\begin{array}{l}\text { Ramazan } \\
\text { Bayramı ve } \\
\text { Vazifelerimiz }\end{array}$ & L. Doğan & 1978 & Eylül & $\begin{array}{l}\text { Ramazan } \\
\text { Bayramı }\end{array}$ & L. Şentürk \\
\hline 1971 & Ekim & $\begin{array}{l}\text { Rahmet ve } \\
\text { Gufran ayı } \\
\text { Ramazan }\end{array}$ & L. Doğan & 1979 & Temmuz & $\begin{array}{l}\text { Mübarek } \\
\text { Ramazan }\end{array}$ & L. Şentürk \\
\hline 1973 & Ekim & $\begin{array}{l}\text { Ramazan } \\
\text { Geldi }\end{array}$ & $\begin{array}{l}\text { Dr. L. } \\
\text { Doğan }\end{array}$ & 1979 & Ağustos & $\begin{array}{l}\text { Ramazanı } \\
\text { anlamak }\end{array}$ & H. Mert \\
\hline 1973 & Ekim & $\begin{array}{l}\text { Ramazan } \\
\text { Bayramı }\end{array}$ & $\begin{array}{l}\text { Dr. L. } \\
\text { Doğan }\end{array}$ & 1979 & Eylül & $\begin{array}{l}\text { Ramazana } \\
\text { Veda } \\
\text { Ederken }\end{array}$ & L. Şentürk \\
\hline 1974 & Eylül & Ramazan Ayı & $\begin{array}{l}\text { Dr. L. } \\
\text { Doğan }\end{array}$ & 1980 & Temmuz & $\begin{array}{l}\text { Ramazan Bir } \\
\text { Muhasebedir }\end{array}$ & H. Mert \\
\hline 1975 & Eylül & $\begin{array}{l}\text { Mübarek } \\
\text { Ramazan-1 } \\
\text { Şerif Şeref } \\
\text { verdi }\end{array}$ & $\begin{array}{l}\text { Dr. L. } \\
\text { Doğan }\end{array}$ & 1981 & Haziran & $\begin{array}{l}\text { Ramazana } \\
\text { Girerken }\end{array}$ & H. Mert \\
\hline 1975 & Ekim & Ramazan Ayı & $\begin{array}{l}\text { Dr. L. } \\
\text { Doğan }\end{array}$ & 1981 & Temmuz & $\begin{array}{l}\text { Ramazan } \\
\text { Manevi Bir } \\
\text { Yenilenme } \\
\text { Olmalıdır }\end{array}$ & H. Mert \\
\hline
\end{tabular}




\begin{tabular}{|l|l|l|l|l|l|l|l|}
\hline 1976 & Eylül & $\begin{array}{l}\text { Mübarek } \\
\text { Ramazan Ay1 }\end{array}$ & S. Ateş & 1982 & Haziran & $\begin{array}{l}\text { Ramazana } \\
\text { Ulaşırken }\end{array}$ & $\begin{array}{l}\text { N. } \\
\text { Baloğlu }\end{array}$ \\
\hline 1977 & Eylül & $\begin{array}{l}\text { Bayram geldi } \\
\text { Ramazan }\end{array}$ & S. Ateş & 1984 & Haziran & $\begin{array}{l}\text { Ramazana } \\
\text { Girerken }\end{array}$ & $\begin{array}{l}\text { T. } \\
\text { Altıkulaç }\end{array}$ \\
\hline 1978 & Ağustos & $\begin{array}{l}\text { Ramazana } \\
\text { Girerken }\end{array}$ & $\begin{array}{l}\text { L. } \\
\text { Şentürk }\end{array}$ & 1985 & Mayıs & $\begin{array}{l}\text { Ramazan'a } \\
\text { Girerken }\end{array}$ & H. Güler \\
\hline 1978 & Ağustos & $\begin{array}{l}\text { Ramazan ve } \\
\text { Özellikleri }\end{array}$ & $\begin{array}{l}\text { H. } \\
\text { Sevgin }\end{array}$ & & & & \\
\hline
\end{tabular}

\subsubsection{Camiler ve Din Görevlileri}

Tablo 8. Camiler ve Din Görevlileri Konusunda Diyanet Gazetesi Başyazı Gündemleri

\begin{tabular}{|c|c|c|c|c|c|c|c|}
\hline Yil & Ay & Başyazı Gündemi & Yazan & Yil & Ay & $\begin{array}{l}\text { Başyazı } \\
\text { Gündemi }\end{array}$ & Yazan \\
\hline 1974 & A ğustos & $\begin{array}{l}\text { Din Görevlilerine } \\
\text { Hitap }\end{array}$ & $\begin{array}{l}\text { Dr. L. } \\
\text { Doğan }\end{array}$ & 1981 & Nisan & $\begin{array}{l}\text { Şehit Mora'lı } \\
\text { ve Arı'nın } \\
\text { Ardından }\end{array}$ & H. Mert \\
\hline 1976 & Aralık & $\begin{array}{l}\text { Din Görevlisi } \\
\text { Arkadaşlarıma }\end{array}$ & S. Ateş & 1982 & Şubat & $\begin{array}{l}\text { Gurur Verici } \\
\text { Tebrik }\end{array}$ & H. Mert \\
\hline 1978 & Şubat & $\begin{array}{l}\text { Din Görevlilerinin } \\
\text { Toplumumuzdaki } \\
\text { Yeri }\end{array}$ & $\begin{array}{l}\text { T. } \\
\text { Altıkulaç }\end{array}$ & 1982 & Ağustos & $\begin{array}{l}\text { Fitne Her } \\
\text { Zaman Var } \\
\text { Olmuştur } \\
\text { Ama Hizmet } \\
\text { Yürüyecektir }\end{array}$ & Diyanet \\
\hline 1978 & May1s & $\begin{array}{l}\text { Anarşi } \\
\text { Konusunda Din } \\
\text { Görevlilerine } \\
\text { Düşen }\end{array}$ & H. Mert & 1983 & Nisan & $\begin{array}{l}\text { Dini } \\
\text { Hizmetler }\end{array}$ & H. Güler \\
\hline 1978 & Kasım & $\begin{array}{l}\text { Din Hizmeti Ve } \\
\text { Partiler }\end{array}$ & H. Mert & 1986 & Ekim & $\begin{array}{l}\text { Camiler } \\
\text { Haftası }\end{array}$ & H. Güler \\
\hline 1978 & Aralık & $\begin{array}{l}\text { Din Hizmeti } \\
\text { Vahdeti Gerektirir }\end{array}$ & H. Mert & 1989 & Temmuz & $\begin{array}{l}\text { Hizmette } \\
\text { Yeni Anlayış }\end{array}$ & $\begin{array}{l}\text { M.S. } \\
\text { Yazıcıŏlu }\end{array}$ \\
\hline 1979 & Ocak & $\begin{array}{l}\text { Din Hizmetinde } \\
\text { Strateji Tespiti }\end{array}$ & H. Mert & 1990 & Ekim & $\begin{array}{l}\text { Dinimizde } \\
\text { Ve Toplum } \\
\text { Hayatımızda } \\
\text { Camilerin } \\
\text { Önemi } \\
\end{array}$ & S. Yazıc1 \\
\hline 1979 & May1s & $\begin{array}{l}\text { Din Hizmetinde } \\
\text { İnsan Sevgisi ve } \\
\text { Hoşgörü }\end{array}$ & H. Mert & & & & \\
\hline
\end{tabular}




\subsubsection{Farklı Dinî Sosyo-Kültürel Konular}

Tablo 9. Farklı Dinî Sosyo-Kültürel Konularda Diyanet Gazetesi Başyazı Gündemleri

\begin{tabular}{|c|c|c|c|c|c|c|c|}
\hline Y11 & Ay & $\begin{array}{l}\text { Başyazı } \\
\text { Gündemi }\end{array}$ & Yazan & Yil & Ay & $\begin{array}{l}\text { Başyazı } \\
\text { Gündemi }\end{array}$ & Yazan \\
\hline 1971 & Şubat & $\begin{array}{l}\text { İslamiyet Güzel } \\
\text { Ameller } \\
\text { Manzumesidir. }\end{array}$ & L. Doğan & 1975 & Şubat & $\begin{array}{l}\text { Çalışmanın } \\
\text { Değeri }\end{array}$ & $\begin{array}{l}\text { Dr. L. } \\
\text { Doğan }\end{array}$ \\
\hline 1971 & Şubat & $\begin{array}{l}\text { Hakka Saygı } \\
\text { Müminin } \\
\text { Şiarıdır. }\end{array}$ & L. Doğan & 1975 & Mayıs & İnsanın Değeri & $\begin{array}{l}\text { Dr. L. } \\
\text { Doğan }\end{array}$ \\
\hline 1971 & Nisan & $\begin{array}{l}\text { İsraftan } \\
\text { Kaçınmak }\end{array}$ & L. Doğan & 1975 & Haziran & $\begin{array}{l}\text { İslam'da Din } \\
\text { Hürriyeti }\end{array}$ & $\begin{array}{l}\text { Dr. L. } \\
\text { Doğan }\end{array}$ \\
\hline 1971 & Nisan & $\begin{array}{l}\text { Başarının Sırrı } \\
\text { Allah İçin } \\
\text { Sevmektir } \\
\end{array}$ & L. Doğan & 1975 & Temmuz & Müminin İşi & $\begin{array}{l}\text { Dr. L. } \\
\text { Doğan }\end{array}$ \\
\hline 1971 & Mayıs & $\begin{array}{l}\text { Dinimizde } \\
\text { Komşuluk } \\
\text { Münasebetler }\end{array}$ & L. Doğan & 1976 & Şubat & Tevekkül & $\begin{array}{l}\text { Dr. L. } \\
\text { Doğan }\end{array}$ \\
\hline 1971 & Haziran & Doğruluk & L. Doğan & 1976 & Temmuz & $\begin{array}{l}\text { İlişkilerimizin } \\
\text { Değeri }\end{array}$ & S. Ateş \\
\hline 1971 & Haziran & $\begin{array}{l}\text { İyi Şeylerin } \\
\text { Düşünülmesi }\end{array}$ & L. Doğan & 1977 & Şubat & Sosyal Adalet & S. Ateş \\
\hline 1971 & Temmuz & $\begin{array}{l}\text { İki Günümüzün } \\
\text { Müsavi } \\
\text { Olmaması } \\
\text { Gerekir. }\end{array}$ & L. Doğan & 1977 & Mart & $\begin{array}{l}\text { İslam'ın } \\
\text { Kadınlara } \\
\text { Getirdikleri }\end{array}$ & S. Ateş \\
\hline 1971 & Ağustos & $\begin{array}{l}\text { Çocuklarımıza } \\
\text { İyilik Yapma } \\
\text { Alışkanlığı } \\
\text { Kazandırmalıyız. }\end{array}$ & L. Doğan & 1977 & Mayıs & $\begin{array}{l}\text { Mümin } \\
\text { Öfkesine } \\
\text { Hakim } \\
\text { Olmalıdır }\end{array}$ & S. Ateş \\
\hline 1971 & Aralık & Din Muameledir & L. Doğan & 1977 & Haziran & $\begin{array}{l}\text { Adam } \\
\text { Kayırma }\end{array}$ & S. Ateş \\
\hline 1972 & Şubat & $\begin{array}{l}\text { Allah'ın Yardımı } \\
\text { Sabredenlerle } \\
\text { Beraberdir. }\end{array}$ & L. Doğan & 1977 & Ekim & $\begin{array}{l}\text { Rüssvet ve } \\
\text { İltimas }\end{array}$ & S. Ateş \\
\hline 1972 & Mart & $\begin{array}{l}\text { Kanaat } \\
\text { Tükenmez Bir } \\
\text { Hazine }\end{array}$ & L. Doğan & 1977 & Ekim & $\begin{array}{l}\text { Batı } \\
\text { Trakya'dan } \\
\text { Geliyorum }\end{array}$ & S. Ateş \\
\hline 1972 & Nisan & $\begin{array}{l}\text { Komşu Hakkına } \\
\text { Sayglı Olmak }\end{array}$ & L. Doğan & 1978 & Haziran & Nimete Şükür & H. Sevgin \\
\hline 1972 & Temmuz & $\begin{array}{l}\text { İstişarenin } \\
\text { Önemi ve } \\
\text { Dinimizdeki Yeri }\end{array}$ & L. Doğan & 1978 & Ekim & Kabir Ziyareti & L. Şentürk \\
\hline 1972 & Ağustos & $\begin{array}{l}\text { Dinimiz } \\
\text { Emanetleri } \\
\text { Güzel Bir Şekilde } \\
\text { Korumamızı } \\
\text { Emreder }\end{array}$ & L. Doğan & 1979 & Mayıs & $\begin{array}{l}\text { Din ve } \\
\text { Toplum }\end{array}$ & L. Şentürk \\
\hline
\end{tabular}




\begin{tabular}{|l|l|l|l|l|l|l|l|}
\hline 1972 & Aralık & $\begin{array}{l}\text { Tutumlu Olmak } \\
\text { Dinin } \\
\text { Esaslarından }\end{array}$ & L. Doğan & 1980 & Haziran & $\begin{array}{l}\text { Köyde } \\
\text { Beklenen } \\
\text { Önder }\end{array}$ & H. Mert \\
\hline 1973 & Ocak & İslam ve Akıl & $\begin{array}{l}\text { Dr. L. } \\
\text { Doğan }\end{array}$ & 1981 & Şubat & $\begin{array}{l}\text { Çağlar } \\
\text { Kuşatan Mesaj }\end{array}$ & H. Mert \\
\hline 1973 & Şubat & Hicret & $\begin{array}{l}\text { Dr. L. } \\
\text { Doğan }\end{array}$ & 1982 & Kasım & $\begin{array}{l}\text { İlam'ı } \\
\text { Anlamak ve } \\
\text { Anlatmak }\end{array}$ & N. Baloğlu \\
\hline 1973 & Haziran & Güven & $\begin{array}{l}\text { Dr. L. } \\
\text { Doğan }\end{array}$ & 1982 & Aralık & $\begin{array}{l}\text { Kültür } \\
\text { Üzerine }\end{array}$ & N. Baloğlu \\
\hline 1973 & Temmuz & Sabır & $\begin{array}{l}\text { Dr. L. } \\
\text { Doğan }\end{array}$ & 1983 & Ekim & $\begin{array}{l}\text { Cumhuriyet } \\
\text { Fazilettir }\end{array}$ & Diyanet \\
\hline 1974 & Ocak & İsraf & $\begin{array}{l}\text { Dr. L. } \\
\text { Doğan }\end{array}$ & 1986 & Eylül & $\begin{array}{l}\text { Afrika'ya } \\
\text { Yardım }\end{array}$ & H. Güler \\
\hline 1974 & Haziran & Kızılay & $\begin{array}{l}\text { Dr. L. } \\
\text { Doğan }\end{array}$ & 1989 & Ocak & $\begin{array}{l}\text { 2000'li Ylllara } \\
\text { Doğru }\end{array}$ & $\begin{array}{l}\text { M.S. } \\
\text { Yazıcığlu }\end{array}$ \\
\hline 1974 & Ekim & Şükür & $\begin{array}{l}\text { Dr. L. } \\
\text { Doğan }\end{array}$ & & & & \\
\hline
\end{tabular}

\subsubsection{Aktüel Konular}

Tablo 10. Bazı Aktüel Konularda Diyanet Gazetesi Başyazı Gündemleri

\begin{tabular}{|l|l|l|l|l|l|l|l|}
\hline Y1l & Ay & $\begin{array}{l}\text { Başyazı } \\
\text { Gündemi }\end{array}$ & Yazan & Yll & Ay & $\begin{array}{l}\text { Başyazı } \\
\text { Gündemi }\end{array}$ & Yazan \\
\hline 1971 & Ekim & $\begin{array}{l}\text { Ö. Nasuhi } \\
\text { Bilmen }\end{array}$ & $\begin{array}{l}\text { L. } \\
\text { Doğan }\end{array}$ & 1977 & Nisan & $\begin{array}{l}\text { Prof. Dr. Tayyib } \\
\text { Okiç }\end{array}$ & S. Ateş \\
\hline 1973 & Mayıs & Seyahat & $\begin{array}{l}\text { Dr. L. } \\
\text { Doğan }\end{array}$ & 1977 & Kasım & $\begin{array}{l}\text { Yugoslavya'ya } \\
\text { Ziyaretim }\end{array}$ & S. Ateş \\
\hline 1974 & Ağustos & $\begin{array}{l}\text { Şeyhülislam } \\
\text { Ebussuud } \\
\text { Efendi }\end{array}$ & $\begin{array}{l}\text { Dr. L. } \\
\text { Doğan }\end{array}$ & 1979 & Kasım & $\begin{array}{l}\text { Hılfu'l } \\
\text { Fudul'dan } \\
\text { İnsan Hakları } \\
\text { Beyannamesi'ne }\end{array}$ & H. Mert \\
\hline 1976 & Mayıs & $\begin{array}{l}\text { Muhammed } \\
\text { İkbal ve } \\
\text { Düşüncesi }\end{array}$ & $\begin{array}{l}\text { Dr. L. } \\
\text { Doğan }\end{array}$ & 1979 & Aralık & $\begin{array}{l}\text { Çocuk Yılı } \\
\text { Değil, İnsanlık } \\
\text { Yllı }\end{array}$ & H. Mert \\
\hline 1977 & Şubat & $\begin{array}{l}\text { Bugünkü } \\
\text { İran }\end{array}$ & S. Ateş & 1980 & Ocak & $\begin{array}{l}\text { Papanın } \\
\text { Ziyaretinden } \\
\text { Kalanlar }\end{array}$ & H. Mert \\
\hline 1977 & Mart & $\begin{array}{l}\text { Meşhed, } \\
\text { Isfahan, } \\
\text { Şiraz }\end{array}$ & S. Ateş & & & & \\
\hline
\end{tabular}




\subsubsection{6. İlim, Bilgi, Eğitim}

Tablo 11. İlim, Bilgi ve Eğitim Konularında Diyanet Gazetesi Başyazı Gündemleri

\begin{tabular}{|c|c|c|c|c|c|c|c|}
\hline Yil & Ay & $\begin{array}{l}\text { Başyazı } \\
\text { Gündemi }\end{array}$ & Yazan & Yil & Ay & $\begin{array}{l}\text { Başyazı } \\
\text { Gündemi }\end{array}$ & Yazan \\
\hline 1970 & Ekim & $\begin{array}{l}\text { Sevindirici Bir } \\
\text { Başlangıç }\end{array}$ & $\begin{array}{l}\text { L. } \\
\text { Doğan }\end{array}$ & 1978 & Mart & $\begin{array}{l}\text { İlmin } \\
\text { Üstünlüğü }\end{array}$ & $\begin{array}{l}\text { T. } \\
\text { Altıkulaç }\end{array}$ \\
\hline 1971 & Aralık & $\begin{array}{l}\text { İlim } \\
\text { Sahiplerinin } \\
\text { Sorumlulukları }\end{array}$ & $\begin{array}{l}\text { L. } \\
\text { Doğan }\end{array}$ & 1979 & Mart & İlim ve Âlim & H. Mert \\
\hline 1972 & May1s & $\begin{array}{l}\text { Çocuğun } \\
\text { Eğitimi, } \\
\text { Terbiyesi }\end{array}$ & $\begin{array}{l}\text { L. } \\
\text { Doğan }\end{array}$ & 1979 & Nisan & $\begin{array}{l}\text { Çocuk } \\
\text { Terbiyesi ve } \\
\text { Günümüzdeki } \\
\text { Problemler }\end{array}$ & H. Sevgin \\
\hline 1972 & Ekim & $\begin{array}{l}\text { Yeni Eğitim } \\
\text { Haftası }\end{array}$ & $\begin{array}{l}\text { L. } \\
\text { Doğan }\end{array}$ & 1980 & Şubat & $\begin{array}{l}\text { Gençlik } \\
\text { Sahipsiz }\end{array}$ & N. Baloğlu \\
\hline 1973 & Eylül & Okumak & $\begin{array}{l}\text { Dr. L. } \\
\text { Doğan }\end{array}$ & 1980 & May1s & $\begin{array}{l}\text { Örnek İnsan } \\
\text { Tipi } \\
\text { Yetiştirmek }\end{array}$ & N. Baloğlu \\
\hline 1973 & Kasim & Bilgin ve Din & $\begin{array}{l}\text { Dr. L. } \\
\text { Doğan }\end{array}$ & 1981 & May1s & $\begin{array}{l}\text { İlahiyat } \\
\text { Fakültesince } \\
\text { Düzenlenen } \\
\text { Din Eğitimi } \\
\text { Seminerinde } \\
\text { Belirlenen } \\
\text { Görüşler }\end{array}$ & H. Mert \\
\hline 1974 & Nisan & Çocuklarımız & $\begin{array}{l}\text { Dr. L. } \\
\text { Doğan }\end{array}$ & 1981 & Haziran & $\begin{array}{l}\text { Aydınlar } \\
\text { Ocağı'nın Milli } \\
\text { Eğitim ve Din } \\
\text { Eğitimi İlmi } \\
\text { Seminerleri } \\
\text { Üzerine }\end{array}$ & H. Mert \\
\hline 1974 & Kasım & $\begin{array}{l}\text { Üniversiteler } \\
\text { Açilırken }\end{array}$ & $\begin{array}{l}\text { Dr. L. } \\
\text { Doğan }\end{array}$ & 1982 & Eylül & $\begin{array}{l}\text { Yeni Anayasa } \\
\text { Tasarısı ve Din } \\
\text { Eğitimi }\end{array}$ & A. Gürtaş \\
\hline 1974 & Aralık & Kitap Sevgisi & $\begin{array}{l}\text { Dr. L. } \\
\text { Doğan }\end{array}$ & 1982 & Ekim & Fikir Ve Laf & N. Baloğlu \\
\hline 1975 & Kasım & $\begin{array}{l}\text { İslam'da İlim } \\
\text { Hürriyeti }\end{array}$ & $\begin{array}{l}\text { Dr. L. } \\
\text { Doğan }\end{array}$ & 1985 & Şubat & $\begin{array}{l}\text { Gençlik } \\
\text { Meselesinde } \\
\text { Yeni Bir } \\
\text { Dönem Mi? }\end{array}$ & H. Mert \\
\hline 1976 & Temmuz & Güzel Söz & $\begin{array}{l}\text { Dr. L. } \\
\text { Doğan }\end{array}$ & 1986 & Nisan & $\begin{array}{l}\text { Çocuğa } \\
\text { Terbiye, Güzel } \\
\text { Hediye }\end{array}$ & H. Güler \\
\hline 1976 & Kasım & $\begin{array}{l}\text { İşçi } \\
\text { Çocuklarının } \\
\text { Eğitimi ile } \\
\text { İlgilenmeliyiz }\end{array}$ & S. Ateş & 1989 & Şubat & $\begin{array}{l}\text { İlahiyat } \\
\text { Meslek } \\
\text { Yüksekokulları } \\
\text { Açılırken }\end{array}$ & $\begin{array}{l}\text { M.S. } \\
\text { Yazıcıŏlu }\end{array}$ \\
\hline 1976 & Kasım & $\begin{array}{l}\text { Müslümanların } \\
\text { İlme } \\
\text { Hizmetleri }\end{array}$ & S. Ateş & 1990 & Kasım & $\begin{array}{l}\text { İslam'ın } \\
\text { İnsanlığa İlk } \\
\text { Emri: Oku }\end{array}$ & S. Yazıc1 \\
\hline
\end{tabular}




\subsubsection{7. Çevre}

Tablo 12. Çevre Konusunda Diyanet Gazetesi Başyazı Gündemleri

\begin{tabular}{|l|l|l|l|l|l|l|l|}
\hline Y1l & Ay & $\begin{array}{l}\text { Başyazı } \\
\text { Gündemi }\end{array}$ & Yazan & Y1l & Ay & $\begin{array}{l}\text { Başyazı } \\
\text { Gündemi }\end{array}$ & Yazan \\
\hline 1974 & Temmuz & $\begin{array}{l}\text { Yeryüzünü } \\
\text { Korumak }\end{array}$ & $\begin{array}{l}\text { Dr. L. } \\
\text { Doğan }\end{array}$ & 1977 & Nisan & $\begin{array}{l}\text { Yurdu } \\
\text { Güzelleştirmek } \\
\text { İçin Ağaç } \\
\text { Dikiniz }\end{array}$ & S. Ateş \\
\hline 1975 & Ocak & $\begin{array}{l}\text { Ağaç } \\
\text { Sevgisi }\end{array}$ & $\begin{array}{l}\text { Dr. L. } \\
\text { Doğan }\end{array}$ & & & & \\
\hline
\end{tabular}

\subsubsection{Helal Duyarlılığı}

Tablo 13. Helal Duyarlılığı Konusunda Diyanet Gazetesi Başyazı Gündemleri

\begin{tabular}{|c|c|c|c|c|c|c|c|}
\hline Y1l & Ay & $\begin{array}{l}\text { Başyazı } \\
\text { Gündemi }\end{array}$ & Yazan & Y1l & Ay & $\begin{array}{l}\text { Başyazı } \\
\text { Gündemi }\end{array}$ & Yazan \\
\hline 1971 & Ocak & $\begin{array}{l}\text { Helal- } \\
\text { Haram }\end{array}$ & L. Doğan & 1972 & Temmuz & $\begin{array}{l}\text { Helal } \\
\text { Kazanç } \\
\text { Temini İçin } \\
\text { Çalışmak } \\
\text { Her } \\
\text { Müslümana } \\
\text { Borçtur }\end{array}$ & L. Doğan \\
\hline
\end{tabular}

\subsubsection{Sağlık}

Tablo 14. Sağlık Konusunda Diyanet Gazetesi Başyazı Gündemleri

\begin{tabular}{|l|l|l|l|l|l|l|l|}
\hline Y1l & Ay & $\begin{array}{l}\text { Başyazı } \\
\text { Gündemi }\end{array}$ & Yazan & Y1l & Ay & $\begin{array}{l}\text { Başyazı } \\
\text { Gündemi }\end{array}$ & Yazan \\
\hline 1973 & Şubat & $\begin{array}{l}\text { İslam ve Ruh } \\
\text { Sağlığ1 }\end{array}$ & $\begin{array}{l}\text { Dr. L. } \\
\text { Doğan }\end{array}$ & 1976 & Ocak & $\begin{array}{l}\text { Din ve } \\
\text { Kadın } \\
\text { Sağllğ1 }\end{array}$ & $\begin{array}{l}\text { Dr. L. } \\
\text { Doğan }\end{array}$ \\
\hline 1973 & Mart & $\begin{array}{l}\text { Kötülüklerin } \\
\text { Anası İçki }\end{array}$ & $\begin{array}{l}\text { Dr. L. } \\
\text { Doğan }\end{array}$ & 1976 & Nisan & $\begin{array}{l}\text { Sağllk ve } \\
\text { Kadın } \\
\text { Eğitimi }\end{array}$ & $\begin{array}{l}\text { Dr. L. } \\
\text { Doğan }\end{array}$ \\
\hline 1974 & Mart & $\begin{array}{l}\text { Yeşilay } \\
\text { Haftası }\end{array}$ & $\begin{array}{l}\text { Dr. L. } \\
\text { Doğan }\end{array}$ & 1988 & Mart & $\begin{array}{l}\text { Yalnız } \\
\text { Sigara mı? }\end{array}$ & H. Güler \\
\hline 1975 & Nisan & Sağlik & $\begin{array}{l}\text { Dr. L. } \\
\text { Doğan }\end{array}$ & & & & \\
\hline
\end{tabular}




\subsubsection{Dinî ve Millî Gün ve Geceler}

Tablo 15. Dinî ve Millî Gün ve Geceler Konusunda Diyanet Gazetesi Başyazı Gündemleri

\begin{tabular}{|l|l|l|l|l|l|l|l|}
\hline Y11 & Ay & $\begin{array}{l}\text { Başyazı } \\
\text { Gündemi }\end{array}$ & Yazan & Yıl & Ay & $\begin{array}{l}\text { Başyazı } \\
\text { Gündemi }\end{array}$ & Yazan \\
\hline 1971 & Eylül & Miraç & $\begin{array}{l}\text { L. } \\
\text { Doğan }\end{array}$ & 1978 & Haziran & $\begin{array}{l}\text { Regaip } \\
\text { Gecesi }\end{array}$ & L. Şentürk \\
\hline 1971 & Kasım & $\begin{array}{l}\text { Dini } \\
\text { Bayramlarımız }\end{array}$ & $\begin{array}{l}\text { L. } \\
\text { Doğan }\end{array}$ & 1978 & Temmuz & Miraç & L. Şentürk \\
\hline 1972 & Şubat & $\begin{array}{l}\text { Kurban } \\
\text { Bayramının } \\
\text { Manevi Değeri } \\
\text { Büyüktür }\end{array}$ & $\begin{array}{l}\text { L. } \\
\text { Doğan }\end{array}$ & 1978 & Kasım & $\begin{array}{l}\text { Kurban } \\
\text { Bayramı }\end{array}$ & $\begin{array}{l}\text { T. } \\
\text { Altıkulaç }\end{array}$ \\
\hline 1972 & Kasım & $\begin{array}{l}\text { Büyük Olaylar } \\
\text { Karşında } \\
\text { Kadir Gecesi) }\end{array}$ & $\begin{array}{l}\text { Dr. L. } \\
\text { Doğan }\end{array}$ & 1979 & Haziran & $\begin{array}{l}\text { Üç Aylar } \\
\text { ve Kadir } \\
\text { Gecesi }\end{array}$ & L. Şentürk \\
\hline 1973 & Eylül & $\begin{array}{l}\text { Berat } \\
\text { Dr. L. } \\
\text { Doğan }\end{array}$ & 1979 & Haziran & $\begin{array}{l}\text { Miraç } \\
\text { Gecesi }\end{array}$ & L. Şentürk \\
\hline 1976 & Ağustos & Berat Kandili & $\begin{array}{l}\text { Dr. L. } \\
\text { Doğan }\end{array}$ & 1979 & Temmuz & $\begin{array}{l}\text { Berat } \\
\text { Gecesi }\end{array}$ & H. Sevgin \\
\hline 1977 & Temmuz & İsrâ ve Miraç & S. Ateş & 1982 & Temmuz & $\begin{array}{l}\text { Kadir'in } \\
\text { Yüceliği }\end{array}$ & $\begin{array}{l}\text { T. } \\
\text { Altıkulaç }\end{array}$ \\
\hline 1977 & Temmuz & Berat Gecesi & S. Ateş & 1985 & Nisan & $\begin{array}{l}\text { 23 } \\
\text { Nisan'da } \\
\text { Çocuklar } \\
\text { ve Biz }\end{array}$ & Diyanet \\
\hline 1977 & Kasım & $\begin{array}{l}\text { Kurban } \\
\text { Bayramı }\end{array}$ & S. Ateş & & & & \\
\hline
\end{tabular}

\subsubsection{Din Kongreleri}

Tablo 16. Din Kongreleri Konusunda Diyanet Gazetesi Başyazı Gündemleri

\begin{tabular}{|l|l|l|l|l|l|l|l|}
\hline Y1l & Ay & $\begin{array}{l}\text { Başyazı } \\
\text { Gündemi }\end{array}$ & Yazan & Yıl & Ay & $\begin{array}{l}\text { Başyazı } \\
\text { Gündemi }\end{array}$ & Yazan \\
\hline 1977 & Aralık & $\begin{array}{l}\text { İslam } \\
\text { Ülkeleri } \\
\text { Ticaret ve } \\
\text { Sanayi } \\
\text { Odaları } \\
\text { Kongreleri }\end{array}$ & S. Ateş & 1981 & Şubat & $\begin{array}{l}\text { Türkiye } \\
\text { İslam } \\
\text { Zirvesinde }\end{array}$ & H. Mert \\
\hline 1980 & Nisan & $\begin{array}{l}\text { 8. Dünya } \\
\text { İslam } \\
\text { Kongresi }\end{array}$ & $\begin{array}{l}\text { N. } \\
\text { Baloğlu }\end{array}$ & & & & \\
\end{tabular}


Diyanet Gazetesi Başyazılarının konuları hakkında verilen bu tablo ve rakamsal verilere bakıldığında, Başyazıların $4^{\prime} \ddot{u ̈}(\% 1,5)$ iman esasları ve inanç konularında, $18^{\prime} \mathrm{i}(\% 6,5)$ ibadetler ve ibadet hayatı hakkında iken; 5'i $(\% 1,8)$ doğrudan ahlak kelimesini içermek üzere ahlak, 18' $\mathrm{i}(\% 6,5)$ birlik ve beraberlik, 232' si $(\% 83,7)$ ise dinî sosyo-kültürel hayatla ilgili olmak üzere toplamda \%92'lik yüksek bir oranla genel kategori olarak ahlak alanını ilgilendiren bir çerçevede olduğu görülmektedir. Diyanet Gazetesi Başyazılarında gerek iman ve ibadetler gerek ahlak gerekse sosyal hayatla ilgili konuların daha çok insanın ve toplumun maddi ve manevi yönden huzurunu merkeze alarak işlendiği ve dolayısıyla hayatın, dinin rahmet yüklü mesajıyla güzelleştirilmesi amacına matuf kaleme alındıkları açık bir şekilde anlaşılmaktadır. Nitekim inancın insanın huzuruna etkisi, mü'minlerin kardeşliği, yardımlaşma, meslek ahlakı, çalışma, sadakat, sevgi ve saygı, güzel amel, israf, din hürriyeti, tevekkül, komşuluk, doğruluk, sabır, kanaat, öfkeye hâkim olma, nimete şükür, güven, ilim, bilgi, yeryüzünü koruma, ağaç dikme vb. konuların işlenmesi bu durumu açıkça ortaya koymaktadır.

\subsection{Diyanet Aylık Dergi Başyazılar}

Ocak 1991'den itibaren yayın hayatına başlayan Diyanet Aylık Dergi'nin Ağustos 2021 tarihi itibariyle 368. sayısı neşredilmiştir. Daha önce yapılan çalışmada görüldüğü üzere $353^{146}$ sayısının gündem konularının 13 adetinin (\%4) iman esasları ve inanç konuları, 25 adetinin (\%7) ibadetler, 15 adetinin (\%4) ahlak -gerek Dergi gündeminde gerek Başyazılarında "ahlak" kelimesinin bizzat kullanıldığ 1 konular-, 32 adetinin (\%9) birlik ve beraberlik, 268 adetinin (\%76) ise Hz. Peygamber (s.a.s); Ramazan ve toplumsal yansımaları; hicret, vakıf, gençlik, sanat, emek, yeni yıl, şiddet, boşanma gibi farklı dinî sosyo-kültürel (toplumsal) konular; irtica, göç, salgın, Afrika, Küdüs, Ayasofya gibi bazı aktüel konular; ilim, bilgi ve eğitim; medya; çevre; iletişim; azınlıklar ve sağlık gibi dinî sosyo-kültürel hayat ve aktüel konularla ilgili olduğu tespit edilmiştir. ${ }^{147}$

2020 Aralıktan sonra yayımlanan 8 dergiden hem Dergi hem Başyazı gündeminin aynı olduğu görülmektedir. Buna göre 2021 Ocak (tevhid) ve Ağustos (vahiy) sayıları iman esasları ve inanç, 2021 Mayıs (dijital dünyada ahlak) sayısı ahlak, 2021 Temmuz (radikalizm) sayısı birlik ve beraberlik, 2021 Şubat (Yunus

\footnotetext{
146 İlgili çalışmada Ocak 1991'den Şubat 2020'ye kadar yayımlanan 362 sayının 7 (yedi)'sine gerek fiziki gerek dijital ortamda ulaşılamamıştır. Bu çalışmadaki değerlendirmeler Aralık 2020 tarihi itibariyle yayımlanan 360 derginin kendilerine ulaşılan 353 sayısı üzerinden yapılmıştır. Söz konusu 353 sayının birinde (Ağustos 2004) ise Başyazı bulunmamaktadır. Dolayısıyla değerlendirilen sayı adedi 352' dir. İlgili çalışmada bu rakam sehven 253 olarak zikredilmiştir. Üçer-Çelebi, “Diyanet Aylık Dergi ile Başyazılarının Gündem Konuları", 142. Halbuki metin içerisinde verilen sayılar toplandığında rakam 353 olmaktadır. Bu itibarla doğrusu 353'tür.

${ }_{147}$ Üçer-Çelebi, "Diyanet Aylık Dergi ile Başyazılarının Gündem Konuları”, 142-166. Gerek ilgili çalışmada gerek bu çalı̧̧mamızda tablo ve şekiller Microsoft Office Excel programında yapılmıştır.
} 
Emre), Mart (su), Nisan (Ramazan), Haziran (sanat) sayıları ise dinî sosyo-kültürel hayat hakkındadır. Bu durumda 361 sayının gündem konularının 15 adetinin (\%4) iman esasları ve inanç, 25 adetinin (\%7) ibadetler, 16 adetinin (\%4,5) ahlak, 33 adetinin (\%9) birlik ve beraberlik, 272 adetinin $(\% 75,5)$ dinî sosyo-kültürel hayat ve aktüel konularla ilgili olduğu anlaşılmaktadır. Bu durumda Diyanet Aylık Dergi gündem konularının 40 adeti (\%11) iman esasları ve inanç konuları ve ibadetler hakkında iken, 320 adeti doğrudan ahlak kelimesini içermek üzere ahlak, birlik ve beraberlik, dinî sosyo-kültürel hayatla ilgili olmak üzere toplamda \%89'luk yüksek bir oranla genel kategori olarak ahlak alanını ilgilendiren bir çerçevede olduğu görülmektedir.

Şekil 2. Diyanet Aylık Dergi Gündemlerinin Ana Konulara Göre Yüzdelik Dağılımı

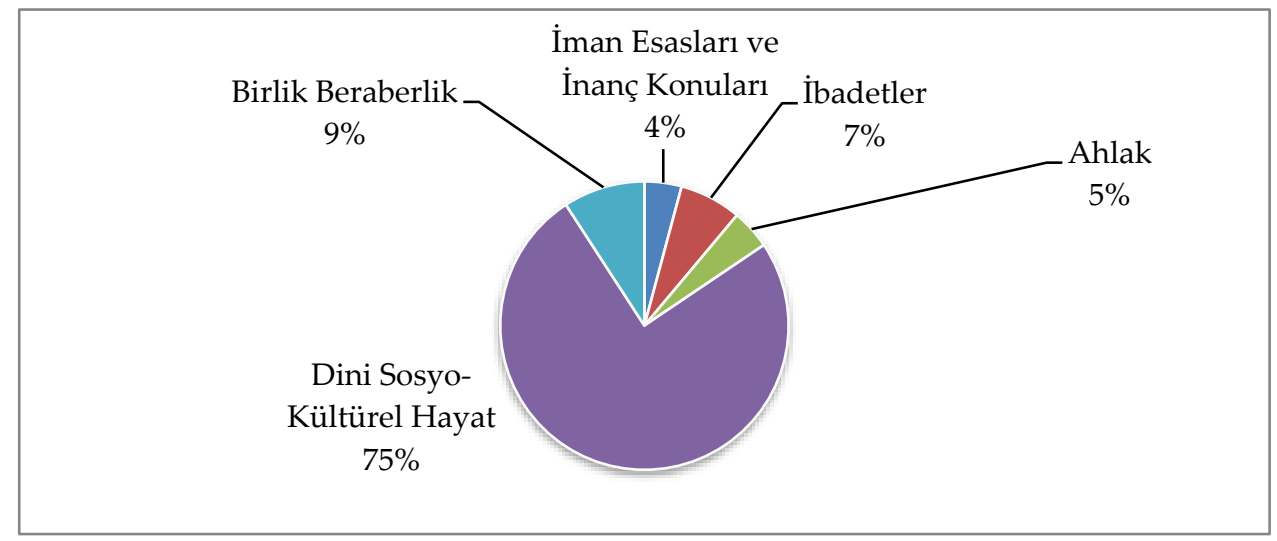

Diyanet Aylık Dergi'nin 2020 Aralık itibariyle neşredilen 352 Başyazısının ${ }^{148}$ konu dağılımları Dergi gündemlerindeki konu dağılımına yakındır. Buna göre Başyazıların 10 adeti (\%3) iman esasları ve inanç, 28 adeti (\%8) ibadetler, 13 adeti (\%3) ahlak, 31 adeti (\%9) birlik ve beraberlik, 270 adeti (\%77) dinî sosyo-kültürel hayat ve aktüel konularla ilgilidir. ${ }^{149}$

Diyanet Aylık Dergi'nin 2021 Ağustos itibariyle neşredilen 360 Başyazısının konu dağılımları Dergi gündemlerindeki konu dağılımına yakındır. Buna göre Başyazıların 12 adeti (yaklaşık \%3,3) iman esasları ve inanç, 28 adeti (yaklaşık \%7,7) ibadetler, 14 adeti (yaklaşık \%3,8) ahlak, 32 adeti (yaklaşık \%8,8) birlik ve beraberlik, 274 adeti (yaklaşı \%76) dinî sosyo-kültürel hayat ve aktüel konularla ilgilidir. Buna göre Diyanet Aylık Dergi'nin Başyazıların da (360) 40 adeti (yaklaşık \%11) iman esasları ve inanç konuları ile ibadetler hakkında iken; 320'si ahlak, birlik ve beraberlik, dinî sosyo-kültürel hayatla ilgili olmak üzere toplamda yaklaşık \%89'lik

148 Fiziki ve dijital olarak ulaşılamayan 7 sayının yanı sıra 1 dergide (Ağustos 2004) Başyazı bulunmamaktadır. Dolayısıyla Başyazılar hakkındaki değerlendirme 352 Başyazı üzerinden yapılmıştır. Üçer-Çelebi, “Diyanet Aylık Dergi ile Başyazılarının Gündem Konuları”, 142.

149 Üçer-Çelebi, “Diyanet Aylık Dergi ile Başyazılarının Gündem Konuları”, 144. 
yüksek bir oranla genel kategori olarak ahlak alanını ilgilendiren bir çerçevede olduğu görülmektedir.

Şekil 3. Aylık Dergi Başyazı Gündemlerinin Ana Konulara Göre Yüzdelik Dağılımı

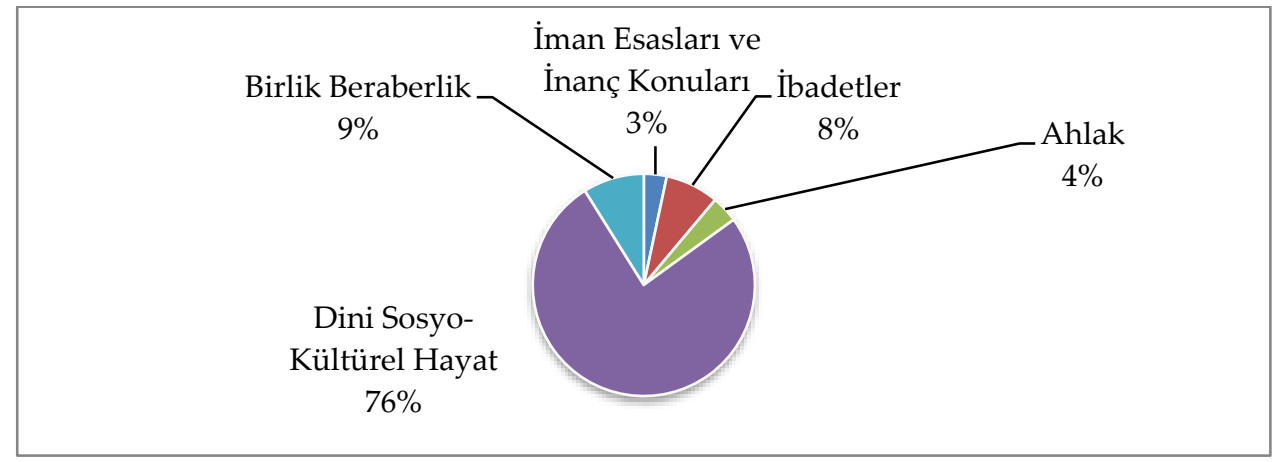

Yukarıda Diyanet Aylık Dergi ve Başyazılarının gündemleri ve konularının bütün Başkanlar beraberce ele alınarak ortaya konulan konu yüzdelikleri hakkında Başkanlar ayrı ayrı ele alındığında da yakın bir tablo ile karşılaşılmaktadır. İman ve ibadetler dışındaki bütün konular ahlak başlığında ele alınabilecek muhtevada olmakla beraber ahlak kelimesinin başlıkta kullanıldığı yazılar olması hasebiyle bunu ayrı bir başlık olarak ele alırken; birlik ve beraberlik hakkındaki konuların da dinî sosyo-kültürel konular başlığı içerisinde ele alınması durumunda ortaya çıkan tablo bunu açıkça teyit etmektedir.

Şekil 4. Prof. Dr. M. S. Yazıcıoğlu'na Ait Başyazı Gündemlerinin Ana Konulara Göre Yüzdelik Dağılımı

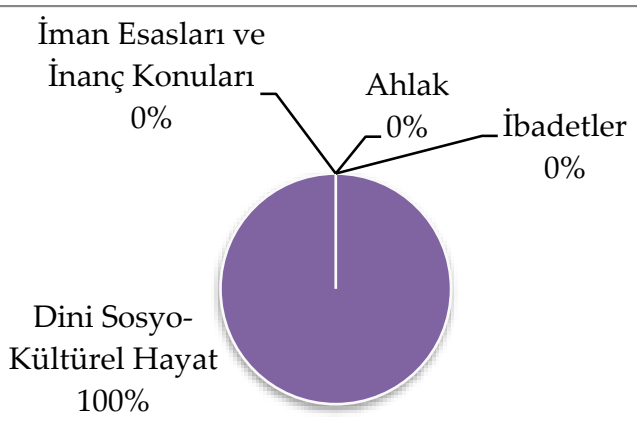


Şekil 5. M. N. Yılmaz'a Ait Başyazı Gündemlerinin Ana Konulara Göre Yüzdelik Dağılımı

\begin{tabular}{|c|c|} 
İman Esasları ve \\
İnanç Konuları \\
Dini Sosyo- \\
Kültürel Hayat \\
85\%
\end{tabular}

Şekil 6. Prof. Dr. A. Bardakoğlu'na Ait Başyazı Gündemlerinin Ana Konulara Göre Yüzdelik Dağılımı

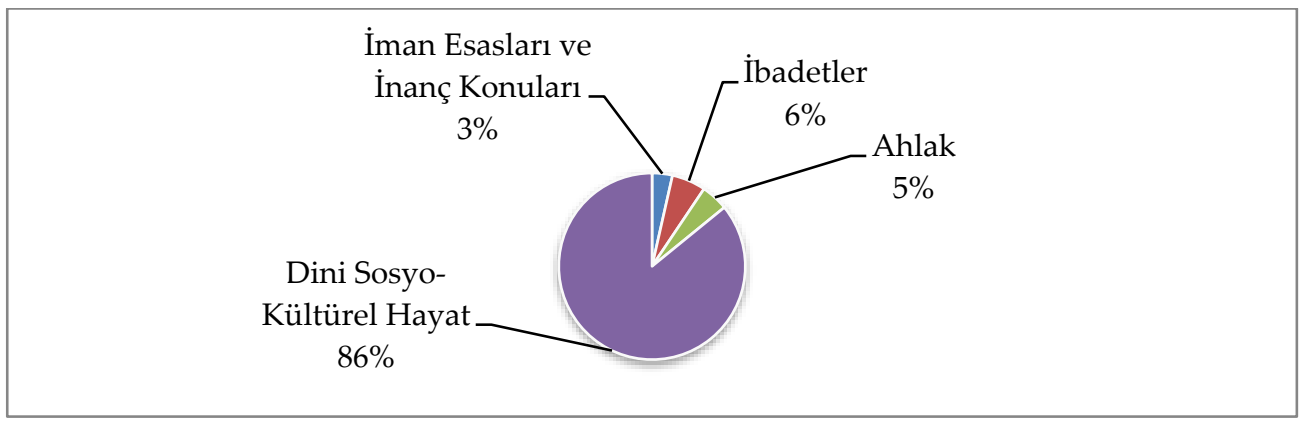

Şekil 7. Prof. Dr. M. Görmez'e Ait Başyazı Gündemlerinin Ana Konulara Göre Yüzdelik Dağılımı

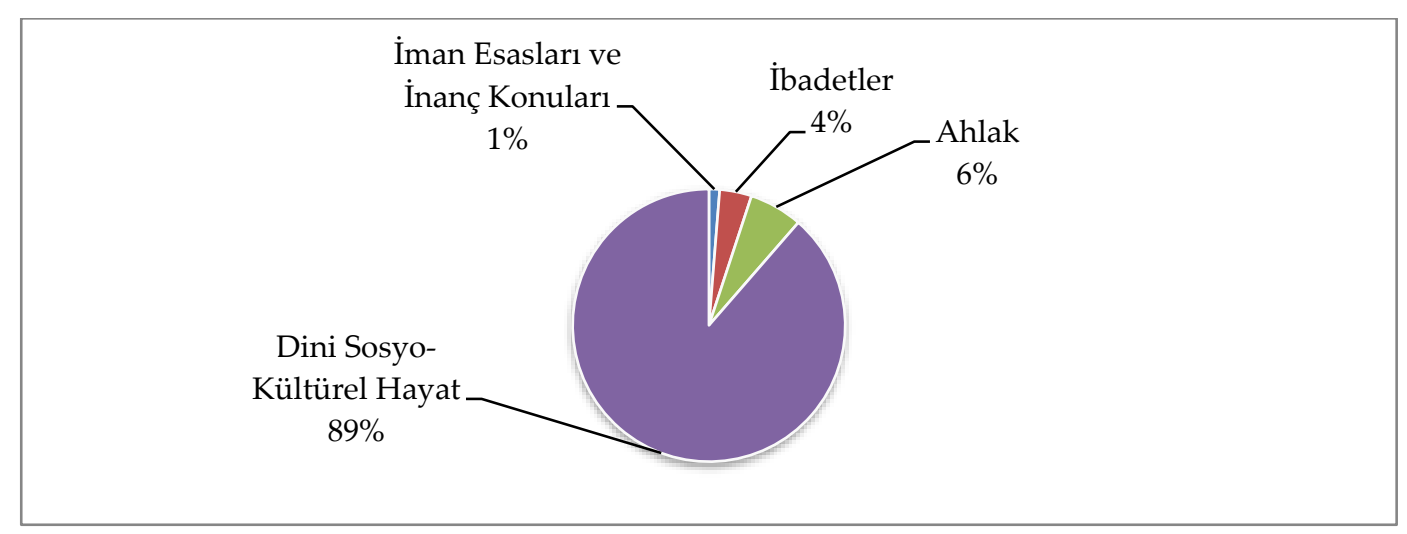


Şekil 8. Prof. Dr. A. Erbaş'a Ait Başyazı Gündemlerinin Ana Konulara Göre Yüzdelik Dağılımı

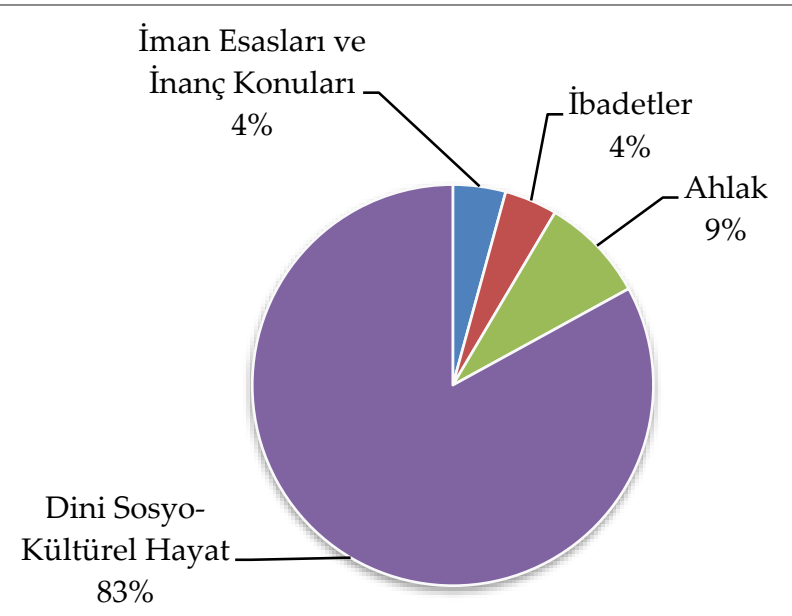

Bu durumda bütün Başkanların daha çok dinî sosyo-kültürel hayatla ilgili konuları merkeze aldığı görülmektedir. Bunda gerek dinî düşünce gerek din devlet ilişkilerinin gerekse hizmet yürüten kurumların yapı ve hizmet anlayışlarının bütün dünyadaki siyasi, fikrî ve fiilî durumlara göre şekil almasının bir sonucunu görmek mümkündür. Zira bir tarafta devletin laiklik ilkesi bağlamında din konusunda resmî bir tercihte bulunmaması, diğer tarafta din hizmetlerini koordine eden ve istikrarlı bir şekilde ifası için gerekli pratik tercihlerde bulunan Diyanet İşleri Başkanlığının kamu kurumu olmasına rağmen resmî bir din görüşü üretmemesi, yanı sıra din konusunda sadece dinî bilgilendirme yapıp bireyin din konusundaki özgürlük alanına müdahalede bulunmamasi; öbür taraftan da dinî söylemin günümüzde sivilleşmesi, öznelleşmesi, kişisel erdemlerden hareketle sosyal ahlakı inşaya yönelmesi ${ }^{150}$ olguları Başkanlığın dinî söylemini de şekillendirmiş, neticede Diyanet İşleri Başkanları kaleme aldıkları Başyazılarda \%90'lara varan bir oranda sosyal içerikli konuları işlemiştir. Bu durumda din söylemi, din üzerine konuşmak bağlamında dinin ana öğretisinin tanıtımı ve hâdiseleri dinle ilişkilendirmek kapsamında dinin dolaylı ilgi alanlarının tespiti ya da üretilmesi açısından değerlendirildiğinde Başkanlığın din söyleminin iman esasları ve ibadet hayatı ile beraber dinin sosyal hayatın pek çok farklı alanıyla ilgili mesajını kamuoyu ile paylaşma yoluna gittiği görülmektedir. Bu Başkanların ve Başkanlığın İslâm dininin ilgi alanı hakkında sosyal alanı dikkate alan bir yaklaşım ve -belki bahsedilen sosyal ahlakı inşaya dönük- fiilî bir tavır sergilediklerini ortaya koymaktadır. ${ }^{151}$

\footnotetext{
150 Bardakoğlu, “Din Söylemi”, 69; Bardakoğlu, Din ve Diyanet, 1/49-59.

${ }^{151}$ Başkanların makaleleri, konuşma metinleri vb. bir araya getiren eserler de bu çerçeveyi teyit etmektedir. Lütfi Doğan'ın ilgili kitabı, İslam ve Tevhid gibi başlangıç konularından sonra Aile ve Önemi, Gençlerimiz,
} 
Başkanlık tarafından yürütülen Camiler ve Din Görevlileri ile Siret/Kutlu Doğum/Mevlid-i Nebî haftalarının gündem konuları da bu çerçeveyi açıkça teyit etmektedir. 1986 yılından itibaren Camiler Haftası olarak kutlanmaya başlanan 2003 yılında Camiler ve Din Görevlileri Haftası ismini alan ${ }^{152}$ ve 2011 yılından itibaren gündemli olarak kutlanan Camiler ve Din Görevlileri Haftasında 2011'de "Cami ve Çocuk", 2012'de "Engelsiz Cami Engelsiz İbadet", 2013'de "Kadın ve Aile", 2015'te "Namazla Arınma", 2016'da “Kitap", 2017' de "Şehir ve Medeniyet", 153 2018' de " Din Hizmetine Adanmış Ömürler", 2019'da "Hayat", 2020'de "İlim", 2021 yılında ise "Cami ve Vefâ' konuları ele alınmıştır.

1985 yılında Başkan Tayyar Altıkulaç tarafından Hicrî/Kamerî Takvime göre 12 Rebîülevvel gününde Mevlid Kandili'ne tevafuk eden haftada "Siret Haftası" -Bu hafta vesilesiyle yapılan bazı etkinliklere Diyanet Gazetesi'nin 322. sayısında (Aralık 1985, s. 22) yer verilmiştir.- adıyla başlatılan; 1989 yılında Başkan Mustafa Said Yazıcıoğlu döneminde yine Hicrî/Kamerî aya göre "Kutlu Doğum Haftası" adıyla Diyanet Gazetesi'nin Ekim 1989 368. sayısında ilan edilmiştir.- yeniden yürürlüğe konulan, 154 Mehmet Nuri Yılmaz döneminde 1994 yılında Hz. Peygamber'in miladî doğum günü olan 20 Nisan tarihi esas alınarak etkinliklerin yapıldığ ve yurt dışında da bu kapsamda etkinliklerle kutlanan, Bardakoğlu döneminde yurt içi ve yurt dışında değişik etkinliklerle devam eden ve 27 Nisan e-muhtırasına konu olan, 23 Nisan Ulusal Egemenlik ve Çocuk Bayramı bağlamındaki tartışmalar nedeniyle de 14-20 Nisan tarihlerinde kutlanması kararlaştırılan, Mehmet Görmez döneminde yine yurt içi ve yurt dışında yürütülen etkinlikler ile 1989' dan itibaren toplam 28 yıl kesintisiz devam eden Kutlu Doğum Haftası etkinliklerinde farklı sosyal konuları içeren panel, konferans, sempozyum gibi farklı etkinlikler yürütülmekle beraber söz gelimi 2008'da “Hz. Peygamber ve Aile", 2010'da "Kur'an-1 Kerîm", 2011'de "Merhamet Eğitimi", 2012'de "Kardeşlik Ahlakı ve Hukuku", 2013'te "İnsan Onuru", 2014'te "Din ve Samimiyet", 2015'te "Birlikte Yaşama Ahlak1", 2016'da "Tevhid, Vahdet, Kardeşlik ve Birlik", 2017'de ise "Hz. Peygamber ve Güven Toplumu" konuları ana gündem olarak belirlenmiştir.

2017 yılında, 28 yıldır kesintisiz yürütülen Kutlu Doğum Haftasının adı 29 Kasım 2017 tarihli ve 30255 sayılı Resmî Gazetede yayımlanan Yönetmelikle Mevlidi Nebî Haftası olarak değiştirilmiş, tarihi de hicrî takvime göre "Rebîu'l-Evvel ayının on ikinci günü başlangıç kabul edilerek" düzenlenmiş ve böylelikle 1994'ten

\footnotetext{
Adalet, Dürüst Çalışmak, Kumar ve Zararları, İsraf, Helal Kazanç, Birlik olma ve Dayanışmanın Önemi, Fuhuş, İçki, Haram Yeme, İnsan Hayatının Korunmuşluğu, Anarşinin Felaket Olması gibi konu başlıklarıyla ele alınmıştır. Doğan, Toplumun Temelini Sarsan Belli Başlı Problemler, 15-277. Ayrıca bkz. Diyanet Işleri Başkanı Mehmet Nuri Yılmaz'ın Röportajları, Basın Açıklamaları, Sempozyum ve Panel Konuşmaları, Protokol Konuşmaları, Konferans ve Makaleleri, 22-92; 207-247; Bardakoğlu, Din ve Diyanet, 1/21-47, 147-232, 388-441.

152 Altıkulaç, Zorlukları Aşarken, 1/484-484.

153 İsmail Arıc1, “Din Görevlilerine Göre Camiler ve Din Görevlileri Haftası”, Atatürk Üniversitesi Sosyal Bilimler Enstitüsü Dergisi 22 (2018), 730.

${ }_{154}$ Altıkulaç, Zorlukları Aşarken, 1/474-481.
} 
önceki tarihlendirmeye geçilmiştir. 1552018 yılındaki Mevlid-i Nebi Haftası etkinliklerinin ana teması "Hz. Peygamber ve Gençlik", 2019'da "Aile", 2020'de "Çocuk", 2021'de ise "Hz. Peygamber ve Vefâ Toplumu" olarak belirlenmiştir. Gerek Camiler ve Din Görevlileri Haftası gerek Siret/Kutlu Doğum/Mevlid-i Nebî Haftası ana tema konuları da Başkanlığın İslâm dininin ilgi alanı hakkında sosyal alanı dikkate alan bir yaklaşım ve sosyal ahlakı inşaya dönük fiilî bir tavır sergilediği hususunu teyit etmektedir.

\section{Sonuç}

Bu çalışmada Diyanet İşleri Başkanlığının dinî söylemi, Diyanet Gazetesi ve Diyanet Aylık Dergi'de yer alan ve Diyanet İşleri Başkanlarının (Vekili ve Yardımcılarının) kaleminden çıan Başyazılar çerçevesinde ele alınmıştır. Cumhuriyet'e geçişte de Başkanlığa mevcut idarî yapı içerisinde yer verilmiş ve kurum din hizmetlerini kamu görevi olarak yürütmekle yükümlü tutulmuştur. Başkanlık süreç içerisinde kurulan farklı idarî birimler vasıtasıyla mevzuatın yükümlü tuttuğu görevleri yerine getirmektedir. Başkanlığın dinî söylemi, "din söylemini, din üzerine konuşmak ve hâdiseleri dinle ilişkilendirmek şeklinde iki şıkka indirip birincisi bağlamında dinin ana öğretisinin tanıtımı, ikincisi bağlamında ise dinin dolaylı ilgi alanlarının tespiti ya da üretilmesi şeklinde anlayan yaklaşım" kapsamında ele alınmıştır. Başkanlığın dinî söylemi bağlamında Diyanet İşleri Başkanlarının konuşmaları, basın açıklamaları, değişik vesilelerle yayımladıkları mesajlar başta olmak üzere, kurulduğu günden bugüne varlığını devam ettiren Din İşleri Yüksek Kurulunun kararları, mütalaaları ve fetvaları, hutbeler, vaazlar, basılısüreli vb. yayınlar ayrı ayrı, hatta kendi içinde de dünyada ve ülkede yaşanan siyasal, sosyo-ekonomik ve kültürel gelişim ve değişimler, bu gelişim ve değişimlerin yaşandığı ana zaman aralıkları, mevzuatta yaşanan değişiklikler ya da devlet idaresindeki kadroların din devlet ilişkilerine bakışı veya görev alan Başkanların hizmet anlayışları vb. farklı ölçeklerde değerlendirmeye tabi tutulabileceğinde şüphe yoktur. Bununla birlikte Başkanlığın hizmet politikalarının ve hassasiyetlerinin Diyanet İşleri Başkanlarının dilinden kamuoyu ile paylaşıldığı malumdur. Diyanet İşleri Başkanları 1950'li yıllardan beri düzenli olarak neşredilen süreli yayınlarda Başyazılar ile topluma mesajlarını sistematik olarak iletmektedir. Bu itibarla bu yazıda Diyanet Gazetesi ve Diyanet Aylık Dergi Başyazıları merkeze alınarak Başkanlığın dinî söylemi hakkında bazı değerlendirmelerde bulunulmuştur.

Gerek kurumların gerek dinî söylemin geçmişten tevarüs edilen bir takım hususiyetlerle birlikte dünyada ve yerelde yaşanan ve daima birbiriyle irtibatlı bir

${ }^{155}$ Kutlu Doğum Haftası İle Camiler Ve Din Görevlileri Haftasını Kutlama Yönetmeliğinde Değişiklik Yapılmasına Dair Yönetmelik , Resmî Gazete 30255 (29 Kasım 2017). 
şekilde biçim alan siyasî, iktisadî, bilimsel, kültürel vb. gelişmelere göre ortaya çıtı̆ğ ya da şekillendiği hususunda şüphe yoktur. Bu itibarla Cumhuriyet öncesinde gerek bu topraklarda kurulmuş devletlerin gerek irtibatlı oldukları coğrafyalarda kurulan devletlerin idarî yapısı, şer'î hukuk örfî hukuk olgusunu da dikkate alarak bu idarî yapı içerisinde kurgulanmış din-devlet ilişkileri; dinî anlayış ve yapılar; yürütülen din hizmetleri gibi unsurların beraberce göz önünde bulundurulması kaçınılmazdır.

Başkanlık, Osmanlı döneminin Şeyhülislâmlık kurumunun adalet, eğitim, vakıflar ve din hizmetlerine dair yürüttüğ̈ görevlerden sadece din hizmetine ait olanlarını mevzuatla belirlenen sınırlar içerisinde yürütmekle mükellef tutulmuştur. İlgili mevzuatın ise ülkede ve dünyada yaşanan gelişmelere göre şekil aldığı muhakkaktır. Bu durumda Başkanlığın dinî söyleminde ülkemizde 20. yüzyıl sürecinde yaşanan siyasî, iktisadî, kültürel vb. gelişmelerin etkisi olması kaçınılmazdır. Bununla birlikte hem kurumsal hem ilmî gelenek hem de insan unsuru bağlamında -zaman zaman Eş́arîlik etkisi olsa da- gerek dinî anlayış gerek Orta Asya'dan Anadolu'ya coğrafya olarak büyük oranda Hanefî-Mâturîdî kültür havzası ile hemhal olmanın ve neticesinde bu gerçekliğin de dinî söyleme ana unsur haliyle tesir edeceği şüphesizdir. Ancak burada dünyada ve ülkede yaşanan gelişmelere bağlı şekillenen anlayışlar ve kurumsal hassasiyetler bağlamında Başkanlığın İslâm ortak kimliğinde ve bir nevi mezhepler üstü bir anlayışla hizmetlerini yürüttüğü mutlaka vurgulanmalıdır. Asya'dan Avrupa'ya, Afrika'dan Amerika'ya çok geniş bir coğrafya ve farklı mezhebî ve kültürel mensubiyetlere sahip Müslümanlar tarafından Başkanlıktan hizmet talebinde bulunulmasında Başkanlığın söz konusu hizmet anlayışının da etkisi göz ardı edilmemelidir.

Başkanlığın bir mezhebî kimliğinden söz etmek mümkün görünmemektedir. Zira Başkanlık, mevzuatında da yer verildiği üzere toplumu vatandaşlık esaslı ve mezhepler üstü bir anlayışla İslâm üst kimliğinde Kitap ve Sünnet merkezli bir aydınlatmayı temel bir hizmet ilkesi olarak benimseyip bunu işletmeye çalışan bir kurumdur. Bunun için Başkanlığın dinî konularda -Bu sınırlayıcı belirleme 2010'daki kanunî düzenleme ile getirilmiştir.- en yüksek karar ve danışma organı olan Din Iş̧leri Yüksek Kurulunun işleyişi ile karar, mütalaa, fetva ve görüşlerinde uyguladığ1 metodik yaklaşım ve çalışmamızın konusu olan Başkanlığın dinî söylemi dikkate alındığında açıç̧a görülmektedir.

Dinî düşünce ve hayatın, dil, toplumsal yapılar ve zihniyet olguları bağlamında mezhebî ve meşrebî sistematiklerle şekillendiği dikkate alındığında Din İşleri Yüksek Kurulunun karar, mütalaa, fetva ve görüşlerinde bu topraklardaki yerleşik ilmî gelenekler bağlamında bir işleyişi son derece makul olmakla birlikte, Kurulun klasik bir konuda Hanefî mezhebinin görüşlerinin; uygulamanın soru soran kişi için ciddî zorluklar doğurması, bir görüşün yeni bilimsel gelişmelere göre tekrar ele alınması gerektiğinin anlaşılması, görüşün çok zayıf olması, geçmişte yaşanmış ancak bugün itibariyle yaşamayan örflere göre verilmiş olması, toplumsal ihtiyaçları ve sorunları gidermede yetersiz kalması, bir zaruret durumunun ortaya çıması, günümüzün değişen şartlarının -seyahat araçları gibi- eski belirlemeleri manasız ve 
imkansız hale getirmesi gibi hallerde hangi mezhebin görüşü ve sistematiği uygunsa ona göre bir tercihte bulunarak bir işlem ve bilgilendirme yaptığı hususu mutlaka göz önünde bulundurulmalıdır. Kurul günümüz şartlarında ortaya çıkan sigorta, estetik ameliyatı, organ nakli, tüp bebek uygulaması gibi yeni konularda ise Kitap ve Sünnet'in ma'kul, maksûd ve mefhûmundan hareket edip fikhın genel/küllî kuralları/kavâidi ile kendi karar, mütalaa, fetva ve görüşlerini oluşturmaktadır. Kurulun bu temel yaklaşımında 19. yüzyıl sonlarıyla 20. yüzyıl başlarında Osmanlı'nın son dönemleriyle Cumhuriyetin ilk yıllarında ülkemizde ve İslâm dünyasında tartışılan içtihadın ferdî olmaktan çıkarılıp bir müessese haline getirilmesi ya da heyet fetvası/ictihadı fikrinin dikkate alınması gerektiği aşikârdır.

Başkanların kaleme aldıkları Başyazılardaki çerçevede Başkanlığın "bir mezhebî kimliğinden söz etmenin zorluğu" durumunu teyit etmektedir. Zira Diyanet İşleri Başkanları bütün yazılarda İslam'ın herkes için genel geçer olan ortak ilkelerinden hareketle bireysel ve sosyal ahlak inşasına dönük bir tavır sergilemişlerdir. Bu itibarla Başkanlığın tek mezhep anlayışı üzerinden hizmet yürüttüğü ile ilgili ileri sürülen iddialar oldukça ihtiyatla karşılanması gerekmektedir.

Diyanet İşleri Başkanlığının tek mezhep çerçevesinde hizmet verdiği hakkındaki tartışmalarda Alevî geleneğin de işin içerisine katıldığı görülmektedir. Özellikle 1990'lı yıllarda dünyada ve ülkede görülen birtakım gelişmeler bağlamında yaşanan kimlik politikası olgusu bağlamında inşa edilmeye çalışılan Alevî kimliği çerçevesinde; Alevî geleneğin ayrı bir inanç olduğu iddiaları da dahil değişik alanlarda yürütülen tartışmalarda Alevî geleneğin bir mezhep olduğu algisıyla ve "Sünnîlik" karşısında konumlandırıldı̆̆ı görülmektedir. Öncelikle Alevî gelenek bir mezhep değil; tasavvuf düşüncesi ve hayatının söz konusu olduğu bir yapıdır. İkincisi Sünnîlik de bir mezhep değildir. İçinde Maturidîlik ve Eşarîlik gibi itikadî; Hanefîlik ve Şâfîlilik gibi fıkhî mezhepleri barındıran bir çerçeve anlayıştır. Bir diğer husus Alevîlik ile Sünnîlik mukayese edilebilir türdeşler değildir. Ayrıca her ne kadar son yıllarda Alevî geleneğe mensup ocak ve gruplar arasında bir nevi Şiîleştirme çabası bir vâkıa olsa da Alevî gelenek Şiîlik de değildir.

Alevî gelenek mensubu ocak ve grupların her biri bir tasavvuf ve tarikat hayatı sürdüren topluluklardır. Nitekim her bir ocak farklı tasavvufî gelenek mensubiyetine ve silsileye sahip olup âdâb ve erkân açısından farklılıklar taşısa da bilgi kaynağı olarak kabul edilen ilhâm ve keşf, "Ulûhiyyet, Nübüvvet, Velâyet" prensibinin ifade şekli olan "Hakk, Muhammed, Ali” anlayışı, dört kapı- kırk makam çerçevesinde oluşturulan âdâb ve erkân, kelime-i tevhidlerin/Hû'ların getirilip zikirlerin çekildiği cemler, "eline, diline, beline sahip olmak/ edeb yâ Hû" ilkesi etrafında şekillendirilen ahlak anlayışı, "mürşid, pîr, şeyh, dede, rehber, tâlib (mürîd)" şeklinde hiyerarşik olarak oluşturulan insan unsuru ve ocak sisteminin uyarlandığı bir tekke yapılanması vb. unsurlar, söz konusu geleneğe mensup ocak 
ve grupların tasavvuf ve tarikat hayatı bağlamında ele alınması gereken yapılar olduğunu açıkça ortaya koymaktadır.

Günümüzde Alevî olarak isimlendirilen, geleneksel olarak ise Hacı Bektaş, Baba Mansur, Dede Garkın, Hasan Dede, Şücaaddin Velî gibi ocak isimleriyle anılan gelenek mensubu ocak ve grup müntesipleri, her ne kadar Caferî mezhebi ile alakalı bir takım sözlü beyanlarda bulunsalar da -alan araştırmalarının da teyit ettiği üzerebüyük oranda amelî uygulamalarında Hanefî mezhebinin esaslarına göre hareket etmektedir.

Ancak Alevî gelenek de içine katılarak yürütülen Diyanet tartışmalarının, Alevî gelenek mensubu ocak ve grupların tasavvufî kimliği ve mezhebî fiilî durumlarının dikkate alınması yerine; 90'lı yıllarda görülen kimlik politikaları çerçevesinde yanlış bir şekilde Sünnîlik karşısına konumlandırılmış bir pozisyon ve içeriklendirme ile yürütülmesi, olayı mecrası dışına taşımıştır. Bu noktadaki tartışmaların sağlıklı olması adına öncelikle Alevî gelenek mensubu ocak ve grupların geleneksel olarak sahip oldukları tasavvuf karakteri ile mezhebî kabul ve uygulamalarının mutlaka göz önünde bulundurulması gerektiği aşikârdır.

Her ne kadar bu topraklarda var olan dinî düşünce ve hayatın önemli bir parçası olan tasavvuf düşüncesi ve hayatına bigane kalmadan Dergilerin ve Başyazıların gündemlerinde Yunus Emre gibi tasavvuf düşüncesinin sembol isimleri, irfan geleneği gibi anlayışın kendisi ve bazı tasavvuf kavramlarına yer vermiş olsa da Başkanlığın 1924'ten bu yana Alevî geleneğe mensup ocak ve gruplar dahil hiçbir tasavvuf ekolünün gerek tekke ve dergâhı gerek âdâb ve erkânı kapsamında herhangi bir görev tanımı bulunmadığı gibi bu meyanda herhangi bir fiilî hizmeti de olmadığı ya da mevcut mevzuat çerçevesinde olmayacağı da açıktır. $\mathrm{Bu}$ itibarla bu gerçek görmezden gelinerek yapılacak olan Alevî geleneğin statüsünden ana dilde ibadete, âdâb ve erkânın icrâ edildiği mekanlar olan cemevlerinden Başkanlıkla ilgili hizmetlere varıncaya kadar her türlü tartışma, çalışma ve işlemin, mecrası dışında yürütülmesine bağlı olarak sağlıksız ve isabetsiz sonuçlar doğuracağı şüphesizdir.

Diyanet İşleri Başkanlığı Kanunun yüklediği “din konusunda toplumu aydınlatma" görevini, hutbe, vaaz, dini soruları cevaplandırma, cami dersleri, seminerler, konferanslar vb. yanı sıra kurulduğu yıllardan bu günlere basılı, süreli yayınlar, takvim yazıları, televizyon ve radyo programları gibi yürüttügüu yayın faaliyetleri ile yerine getirmektedir. Başkanlığın süreli yayınları arasında önemli bir yer tutan yayını şüphesiz bugün itibariyle Diyanet Aylık Dergi adıyla neşrettiği dergidir. Başkanlığın bu süreli yayınına dair faaliyeti 22 Kasım 1968 yayımlanmaya başlayan ve 15 günde bir neşredilen "Diyanet Gazetesi” ile başlamıştır. Başkanlık Diyanet Gazetesi'ni Kasım 1968'den Aralık 1990'a kadar farklı format ve ebatlarda yayımlamıştır. Başkanlık Diyanet Gazetesi'nin 382. (son) sayısından sonra Ocak 1991'den itibaren Diyanet Gazetesi'nde gerek isim gerek şekil gerekse muhteva olarak bir değişikliğe gitmiştir. Bu değişikliğe göre Diyanet Gazetesi, “Diyanet Aylık 
Dergi" ismiyle aylık yayımlanan bir dergiye dönüştürülmüştür. Ağustos 2021 tarihi itibariyle 368. sayısı yayımlanmıştır. Başkanlığın söz konusu dergilerinde dinin sahih bilgisi ve ona dayalı kültür, sanat ve edebiyat birikimini okurlarıyla paylaşmayı amaçladığı; bu itibarla toplumda yaşanan dinî ve sosyo-kültürel gelişmeleri dikkate alarak farklı alanlarda aktüel gündemlerle okurunun karşısına çıktığı görülmektedir.

Diyanet Gazetesi ve Diyanet Aylık Dergide ilk sayıdan itibaren Başmakale ya da Başyazı adıyla Diyanet İşleri Başkanlarına (Bazen Vekil ve Yardımcıları) ait yazılara yer verilmiştir. Bu yazıların söz konusu süreli yayınların önemli kısımlarından olduğu muhakkaktır. Bu itibarla Diyanet İşleri Başkanlığının dinî söylemi hakkındaki bu çalışmamız, her ne kadar bu konudaki bir çalışma başta Din İşleri Yüksek Kurulunun kararları, mütalaaları, görüşleri ya da faaliyetleri olmak üzere değişik birimler ile hutbeler, takvim yazıları vb. farklı hizmetlerin ayrı ayrı ele alınıp incelenmesini gerektiren bir özelliğe sahipse de, Başkanlığın topluma vermek istediği en güçlü bilgilendirme ve mesajı Diyanet İşleri Başkanı aracıllğıyla vereceğinden hareketle Diyanet Gazetesi ve Diyanet Aylık Dergide yer alan ve Başkanlara ait Başmakale ve Başyazıllar üzerinden konuyu değerlendirmiştir.

Diyanet Gazetesi'nin her sayısında Başyazı yer almamaktadır. Bu itibarla neşredilen Gazete sayısı ile Başyazı sayısı farklııık göstermektedir. 1968 yılının Kasım ayında yayın hayatına başlayan ve 1990 yılına kadar yayımlanan Diyanet Gazetesi 382 sayı olarak neşredilmiş, 382 sayının 277 sayısında Başyazı yer almıştır. Ocak 1991'den itibaren yayın hayatına başlayan Diyanet Aylık Dergi'nin Ağustos 2021 tarihi itibariyle 368. sayısı neşredilmiştir. Bunlardan 7'sine gerek fizikî gerek internet ortamında ulaşılamamıştır. Bir dergide de (2004 Ağustos) Başyazı yer almamaktadır. Dolayısıyla değerlendirmeler ulaşılabilen 360 sayı üzerinden yapılmıştır. Başkanlığın dinî söylemi bağlamında Başyazılardaki konular Başkanlı̆̆a Kanunla tanınan yetkilere bağlı olarak şekillenen iman esasları ve bazı inançlar, ibadet hayatı, ahlak, birlik ve beraberlik ve dinî sosyo-kültürel hayat başlıkları altında incelemeye alınmıştır. Gerek birlik ve beraberlik gerek dinî sosyo-kültürel hayatla ilgili konular her ne kadar ahlak ana başlı̆̆ içerisinde değerlendirilebilecek nitelikte olsa da, yazılarda doğrudan ahlak kelimesinin kullanılmasının yanı sıra Kanunda birlik ve beraberliğe dair yapılan vurgu ile yazılarda daha çok dinî sosyokültürel çerçevenin ön plana çıkartılması böyle bir tasnifi zorunlu kılmıştır. Burada konu dinî sosyo-kültürel hayat ve aktüel konular biraz daha alt kategorilere ayrılarak işlenmiştir. Bu bağlamda dinî sosyo-kültürel hayat ve aktüel konular, Hz. Peygamber; Ramazan ve toplumsal yansımaları; cami ve din görevlileri; israf, saygı, sevgi, komşuluk, doğruluk, hicret vb. farklı dinî sosyo-kültürel konular; Meşhed, Yugoslavya, Papa ziyareti, İnsan Hakları Beyannamesi vb. aktüel konular; ilim ve eğitim; çevre; helal duyarlılığı; sağlık, millî ve dinî gün ve geceler ve din kongreleri gibi alt başlıklar halinde incelemeye tabi tutulmuştur.

Diyanet Gazetesi Başyazılarının 4 adetinin $(\% 1,4)$ iman esasları ve inanç konuları, 18 adetinin $(\% 6,4)$ ibadetler, 5 adetinin $(\% 1,8)$ ahlak, 18 adetinin $(\% 6,4)$ 
birlik ve beraberlik, 232 adetinin $(\% 83,7)$ de dinî sosyo-kültürel hayatla ilgili olduğu görülmektedir. Diyanet Gazetesi Başyazılarının konularının ilgili başlıklara taksimi sonucunda ortaya çıkan bu tablo, Başyazıların 22'sinin (\%8) iman esasları ve inanç konuları ile ibadetler ve ibadet hayatı hakkında iken; 255'inin doğrudan ahlak kelimesini içermek suretiyle ahlak, birlik ve beraberlik ve dinî sosyo-kültürel hayatla ilgili olmak üzere toplamda \%92'lik yüksek bir oranla genel kategori olarak ahlak alanını ilgilendiren bir çerçevede olduğunu göstermektedir.

Buna yakın bir çerçeve gerek Diyanet Aylık Dergi'nin gerek Başyazılarının gündemleri ve konuları bağlamında da söz konusudur. Diyanet Aylık Dergi'nin gündem konularına göz atıldığında fizikî ve internet ortamında ulaşılabilen 360 sayıdan 15 adetinin (\%4) iman esasları ve inanç konuları, 25 adetinin (\%7) ibadetler, 16 adetinin (\%4,5) ahlak, 33 adetinin (\%9) birlik ve beraberlik, 271 adetinin $(\% 75,5)$ ise dinî sosyo-kültürel hayat ve aktüel konularla ilgili olduğu anlaşılmaktadır. Bu durumda Diyanet Aylık Dergi gündem konularının 40 adeti (\%11) iman esasları ve inanç konuları ve ibadetler hakkında iken; 320 adeti doğrudan ahlak kelimesini içermek üzere ahlak, birlik ve beraberlik, dinî sosyo-kültürel hayatla ilgili olmak üzere toplamda \%89'luk yüksek bir oranla genel kategori olarak ahlak alanını ilgilendiren bir çerçevede olduğu görülmektedir.

Diyanet Aylık Dergi'nin 2021 Ağustos itibariyle neşredilen 360 Başyazısının konu dağılımları Dergi gündemlerindeki konu dağılımına yakındır. Buna göre Başyazıların 12 adeti (yaklaşık \%3,4) iman esasları ve inanç konuları, 28 adeti (yaklaşık \%7,8) ibadetler, 14 adeti (yaklaşık \%3,8) ahlak, 32 adeti (yaklaşık \%8,8) birlik ve beraberlik, 274 adeti (yaklaşık \%76) dinî sosyo-kültürel hayat ve aktüel konularla ilgilidir. Buna göre Diyanet Aylık Dergi'nin Başyazıların (360) 40 adeti (yaklaşık \%11) iman esasları ve inanç konuları ile ibadetler hakkında iken; 320'si ahlak, birlik ve beraberlik, dinî sosyo-kültürel hayatla ilgili olmak üzere toplamda yaklaşık \%89'lik yüksek bir oranla genel kategori olarak ahlak alanını ilgilendiren bir çerçevede olduğu görülmektedir.

Bu durumda bütün Başkanların Diyanet Gazetesi ve Diyanet Aylık Dergi Başyazılarında daha çok dinî sosyo-kültürel hayatla ilgili konuları merkeze aldığı görülmektedir. Başyazılarda ahlak ve sosyal hayata ait konulara dair mesajların daha çok ön plana çıktığı dikkat çekmekle birlikte gerek iman ve ibadetler gerek ahlak gerekse sosyal hayatla ilgili konuların daha çok insanın ve toplumun maddî ve manevî yönden huzurunu merkeze alarak işlendiği ve dolayısıyla hayatın; dinin rahmet yüklü mesajıyla güzelleştirilmesi amacına matuf kaleme alındıkları açık bir şekilde anlaşılmaktadır. Gerek Camiler ve Din Görevlileri Haftası gerek Siret/Kutlu Doğum/Mevlid-i Nebî Haftası ana tema konuları da bu durumu teyit etmektedir. Bunda gerek dinî düşünce gerek din devlet ilişkilerinin gerekse hizmet yürüten kurumların yapı ve hizmet anlayışlarının bütün dünyadaki siyasî, fikrî ve fiilî durumlara göre şekil almasının bir sonucunu görmek mümkündür. Zira "bir tarafta devletin laiklik ilkesi bağlamında din konusunda resmî bir tercihte bulunmaması, diğer tarafta din hizmetlerini koordine eden ve istikrarlı bir şekilde ifası için gerekli 
pratik tercihlerde bulunan Diyanet İşleri Başkanlığının kamu kurumu olmasına rağmen resmî bir din görüşü üretmemesi, yanı sıra din konusunda sadece dinî bilgilendirme yapıp bireyin din konusundaki özgürlük alanına müdahalede bulunmaması; öbür taraftan da dinî söylemin günümüzde sivilleşmesi ve kişisel erdemlerden hareketle sosyal ahlakı inşaya yönelmesi olguları" Başkanlığın dinî söylemini de şekillendirmiş, neticede Diyanet İşleri Başkanları kaleme aldıkları Başyazılarda \%90'lara varan bir oranda sosyal içerikli yazılar kaleme almıştır. Bu durumda din söylemi, din üzerine konuşmak bağlamında dinin ana öğretisinin tanıtımı ve hâdiseleri dinle ilişkilendirmek kapsamında dinin dolaylı ilgi alanlarının tespiti ya da üretilmesi açısından değerlendirildiğinde, Başkanlığın din söyleminin iman esasları ve ibadet hayatı ile beraber dinin sosyal hayatın pek çok farklı alanıyla ilgili mesajını kamuoyu ile paylaşma yoluna gittiği görülmektedir. Bu, Başkanların ve Başkanlığın İslâm dininin ilgi alanı hakkında sosyal alanı dikkate alan bir yaklaşım ve bahsedilen sosyal ahlakı inşaya dönük fiilî bir tavır sergilediklerini ortaya koymaktadır. 


\section{Kaynakça}

Abul, Lamia Levent. "Diyanet Gazetesi'nden Diyanet Aylık Dergi'ye". Diyanet Aylık Dergi 300 (Ankara: Diyanet İşleri Başkalığı Yayınları, 2015), 28-33.

Adalığlu, Hasan Hüseyin. "Selçuklular Devri Halifelik Telakkisi”. Geçmişten Günümüze Hilafet. ed. Mustafa Sabri Küçükaşçı - Ali Satan - Abdülkadir Macit. 167200. İstanbul: İlem Yayınları, 2019.

AFM, Avrasya Fetva Meclisi (10-11 Mayıs 2017). https://avrasyafetva. diyanet.gov.tr/sayfa/toplantilar/1-toplanti.

Ak, Ahmet. "Büyük Selçuklular Döneminde Mâturîdî Temsilciler". II. Uluslararası Selçuklu Kültür ve Medeniyeti Sempozyumu Selçuklularda Bilim ve Düşünce. 2/299-318. Konya: Selçuklu Belediyesi Yayınları, 2013.

Akgün, Seçil. “Türkçe Ezan”. Tarih Araştırmaları Dergisi 13/24 (1979/1980), 105113.

Akgün, Vahdettin. “Diyanet Gazetesinde Yayınlanan Hutbeler". Diyanet İlmi Dergi 30/2 (1994), 77-94.

Akgündüz, Ahmet. "Ebussuûd Efendi". Türkiye Diyanet Vakfi İslâm Ansiklopedisi. 10:365-371. İstanbul: TDV Yayınları, 1994.

Aksüt, Hamza. Aleviler Türkiye-Iran-Irak-Suriye-Bulgaristan. Ankara: Yurt Kitap-Yayın, 2009.

Akyıldız, Ali. “Osmanlılar: Siyâsî ve İdârî Teşkilat: Modern Dönem”. Türkiye Diyanet Vakfı İslâm Ansiklopedisi. 33/506-509. İstanbul: TDV Yayınları, 2007.

Akyıldız, Ali. "Şer'iyye ve Evkaf Vekâleti". Türkiye Diyanet Vakfi İslâm Ansiklopedisi. 39:7-8. İstanbul: TDV Yayınları, 2010.

Altıkulaç, Tayyar. "Başyazı". Diyanet Gazetesi 183-187 arası 5 sayı Şubat (1978Nisan 1978); 188-349 arası (May1s 1978 - Mart 1988) 150 sayıdan 2 say1.

Altıkulaç, Tayyar. “Din Şurası”. Diyanet Gazetesi 335 (15 Mayıs 1978), 1, 15.

Altıkulaç, Tayyar. “İslam ve Doğum Kontrolü”. Diyanet İlmi Dergi 14/1 (1988), $5-36$.

Altıkulaç, Tayyar. Zorlukları Aşarken. I-III. Ankara: Türkiye Diyanet Vakfı Yayınları, 2016.

Altuntaş, Halil. “Türkçe İbadet Meselesi”. Diyanet İlmi Dergi 34/1 (1998), 51-70.

Altuntaş, Halil. Diyanet İşleri Başkanlığı Din İşleri Yüksek Kurulu (Tarihçe, Oluşum, İşleyiş ve Faaliyetler). Ankara: Diyanet İşleri Başkanlığı Yayınları, 2020.

Arıc1, İsmail. "Din Görevlilerine Göre Camiler ve Din Görevlileri Haftası", Atatürk Üniversitesi Sosyal Bilimler Enstitüsü Dergisi 22 (2018), 729-743. 
Arıkan, Adem. “İslâm Dünyasının Mezhep Haritası ve Nüfus Dağılımı”. İslâmi Araştırmalar 29/2 (2018), 348-379.

Atay, Rıfat. "Türkçe Ezan Uygulamasının Toplumsal Hafızada Yol Açtı̆̆ Travmalar Üzerine". Ortak Dilimiz Ezan. ed. Mahmut Öztürk. 107-147. İstanbul: Nida Akademi, 2018.

Atay, Rıfat - Arslan, Halil. “Üç Dönem, Üç Takvim: 2002, 2007 ve 2011 Yılları Takvimleri Örneğinde Diyanet Söyleminin Analizi". Dinî Araştırmalar 20/52 (2017), 141-157.

Ateş, Süleyman. "Başyazı". Diyanet Gazetesi 147-182 arası 36 sayı. (Ağustos 1976 - Şubat 1978).

Ateş, Süleyman. “Başyazı: Din Siyasete Âlet Edilemez". Diyanet Gazetesi 182 (1978), 1, 14-15.

Avcı, Casim. "Hilâfet". Türkiye Diyanet Vakfı İslâm Ansiklopedisi. 17: 539-546. İstanbul: TDV Yayınları, 1998.

Avcı, Casim. "Abbâsîler ve Hilâfet". Geçmişten Günümüze Hilâfet. ed. Mustafa Sabri Küçükaş̧̧ - Ali Satan - Abdülkadir Macit. 133-166. İstanbul, İlem Yayınları, 2019.

Aydın, Mehmet Akif. "Osmanlılar: Hukukî-Adlî Yapı" Türkiye Diyanet Vakfı İslâm Ansiklopedisi. 33: 515-521. İstanbul: TDV Yayınları, 2007.

Aydın, Mehmet Akif. "Şeyhülislamlıktan Diyanet İşleri Başkanlığına Din Devlet İlişkileri". Türkiye Cumhuriyeti Devletinin Temel Dinamikleri Açısından 3 Mart 1924 Yasaları ve Günümüze Yansımaları Sempozyumu Bildirileri. h. Hale Şıvgın. 221-226. Ankara: Gazi Üniversitesi Yayınları, 2007.

Aydın, Ömür. "Diyanet İşleri Başkanlığının Hukuki Statüsü Üzerine Tartışmalar". Akademik İncelemeler Dergisi 2019, 14/2 (2019), 239-276.

Aytürk, Nihat - Çelik, Yaşar - Şahinaslan, Enver. “Diyanet İşleri Başkanlığı Teşkilat Tarihçesi”. Diyanet İlmi Dergi 15/1 (1989), 31-66.

Baloğlu, Niyazi. “Başyazı”. Diyanet Gazetesi 188-349 arası (Mayıs 1978 - Mart 1988) 150 sayıdan 11 sayı.

Banaz, Şaban. "Çorumlu Caferileşmiş Alevilerin Caferileşme Süreçleri ve Temel İnanç Esasları". Türk Kültürü ve Hacı Bektaş Veli Araştırma Dergisi 95 (2020), 169-197.

Bardakoğlu, Ali. "Başyazı". Diyanet Aylık Dergi 151-239. (Temmuz 2003 Kasım 2010).

Bardakoğlu, Ali. "Hanefî Mezhebi". Türkiye Diyanet Vakfı İslâm Ansiklopedisi. 16:1-21. İstanbul: TDV Yayınları, 1997. 
Bardakoğlu, Ali. “Osmanlı Hukukunun Şer'îliği Üzerine”. Osmanlı: Teşkilât. 12. Cilt. Ankara: Yeni Türkiye Yayınları, 1999), 4/4123-417.

Bardakoğlu, Ali. “İlahiyatçıların Din Söylemi”. İslâmiyât 4/4 (2001), 63-76.

Bardakoğlu, Ali. 21. Yüzyıl Türkiye'sinde Din ve Diyanet. Ankara: Diyanet İşleri Başkanlığı Yayınları, 2010.

Barkan, Ömer Lutfi. “Osmanlı İmparatorluğu Teşkilat ve Müesseselerinin Şer'iliği Meselesi”. İstanbul Üniversitesi Hukuk Fakültesi Mecmuası 11/3-4 (1945), 203224.

Barkan, Ömer Lutfi. "Türkiye'de Din ve Devlet İlişkilerinin Tarihsel Gelişimi". Türk Tarih Kurumu Cumhuriyetin 50. Yıldönümü Semineri, Seminere Sunulan Bildiriler. 49-97. Ankara: Türk Tarih Kurumu Yayınları, 1975.

Bayar, Mustafa. “Yaygın Din Eğitimi Bağlamında Diyanet İşleri Başkanlığının Süreli Yayın Hizmetleri". Uluslararası Sosyal Araştırmalar Dergisi 8/36 (2015), 453-465.

Bedir, Mürteza. “Usûl-i Fıkhın Geçmişte ve Günümüzdeki Müfredatı -Fıkıh Usûlü Tasavvurunda Büyük Değişim: Fıkıh Usûlü Ders İçeriği Üzerinden Bir İnceleme-“. Kelâm İmi ve İslâm Hukukunda İçerik Sorunları: Tartışmalı İmî İhtisas Toplantısı. 305-337. İstanbul: Üsküdar Belediyesi Yayınları, 2017.

Bolat, Ali - Uyar, Mehmet - Cengiz, Muammer. Tasavouf Tarih, Doktrin, Tenkit. Samsun: E Yazı Yayınevi, 2019.

Boyacıoğlu, Ramazan. Hilafetten Diyanet İşleri Başkanlığına Geçiş. Ankara: Ankara Üniversitesi, Sosyal Bilimler Enstitüsü, Doktora Tezi, 1992.

Boyacıoğlu, Ramazan. “Tarihi Açıdan Şeyhülislamlık, Şer'iye ve Evkaf Vekaleti". Cumhuriyet Üniversitesi İlahiyat Fakültesi Dergisi 1 (1996), 161-171.

Bozkuş, Metin. “Alevî Yurttaşlara Yönelik Dinî Hizmetlerin İcrası Bağlamında Bir Teklif Denemesi”. Cumhuriyet Üniversitesi Illahiyat Fakültesi Dergisi 10/1 (2006), 112.

Bulut, Mehmet. “Diyanet İşleri Reisliği (Başkanlığı) 1341 (1925) Malî Yılı Bütçe Müzakereleri". Diyanet İlmi Dergi 36/1 (2000), 99-128.

Büyükkara, Mehmet Ali. “İslam Kaynaklı Mezheplerin Ortadoğu'daki Coğrafi Dağılımı ve Tahmini Nüfusları”. e-Makâlât Mezhep Araştırmaları 6/2 (2013), 321-354.

Câbirî, Muhammed Âbid. Arap-İslâm Kültürünün Akıl Yapısı, Arap-İslâm Kültüründeki Bilgi Sistemlerinin Eleştirel Bir Analizi. çev. Burhan Köroğlu, Hasan Hacak, Ekrem Demirli. İstanbul: Kitabevi 1999.

Coşkun, Mustafa Asım. Geleneksellik ve Modernlik Ekseninde Diyanet İşleri Başkanlı̆̆ı Hizmet İçi Ĕğitim İhtisas Kursları. İstanbul: İstanbul Üniversitesi, Sosyal Bilimler Enstitüsü, Doktora Tezi, 2010. 
Çakır, Rıdvan. “Başyazı”. Diyanet Aylık Dergi 148-150. (Nisan 2003 - Haziran 2003).

Çakır, Ruşen - Bozan, İrfan. Sivil, Şeffafve Demokratik Bir Diyanet İ̧sleri Mümkün mü? İstanbul: Tesev Yayınları, 2005.

Çifçi, Osman Zahid, "Batı'da Din-Devlet İlişkilerinde Ortaya Çıkan Dönemler". ISTEM: İslam Sanat, Tarih, Edebiyat ve Musikisi Dergisi 10/19 (2012), 195208.

Çifçi, Osman Zahid - Erdem, Hüsamettin. "İslam Siyaset Tarihinde Din ve Devlet İlişkisi". ISTEM: İslâm, San'at, Tarih, Edebiyat ve Mûsikîsi Dergisi 11/22 (2013),117-129.

Dadaş, Mustafa Bülent. “Kuruluşundan Günümüze Din İşleri Yüksek Kurulunun Fetva Siyaseti". Türkiye Araştırmaları Literatür Dergisi 13/25-26 (2015), 3774 .

Dadaş, Mustafa Bülent. “Bir Fetva Belirleme Yöntemi Olarak Heyet İçtihadı ve İslam Dünyasında Bu Amaçla Kurulan Fıkıh Meclisleri”. Bilimname: Düşünce Platformu 28 (2015/1), 311-342.

Dağcl, Şamil. Din İşleri Yüksek Kurulu Kararlarına Fetva Konseptinde Bir Yaklaşım". Diyanet İlmi Dergi 38/4 (2002), 5-20.

Demir, Şerif. “Ezanın Türkçe Okunması (1932-1950)”. Ortak Dilimiz Ezan. ed. Mahmut Öztürk. 85-106. İstanbul: Nida Akademi, 2018.

DİB Kanun, Diyanet İşleri Başkanlığı Kuruluş ve Görevleri Hakkında Kanun (Kanun No. 633). Resmî Gazete 12038 (2 Temmuz 1965). Erişim 5 Eylül 2021. https://www.mevzuat.gov.tr/MevzuatMetin/1.5.633.pdf.

DİB Değişiklik Kanun, Diyanet İşleri Başkanlığı Kuruluş ve Görevleri Hakkında Kanun ile Bazı Kanunlarda Değişiklik Yapılmasına Dair Kanun (Kanun No: 6002). Resmî Gazete 27640 (13.07.2010). Erişim 5 Eylül 2021. https://www.resmigazete.gov.tr/eskiler/2010/07/20100713-2.htm.

DíB, Diyanet İşleri Başkanlığı. “Dini Yayınlar Genel Müdürlüğü”. Erişim 05 Eylül 2021. https://diniyayinlar.diyanet.gov.tr/sayfa/53/tanitim.

DíB, Diyanet İşleri Başkanlığı. Diyanet İşleri Başkanı Mehmet Nuri Yılmaz'ın Röportajları, Basın Açılamaları, Sempozyum ve Panel Konuşmaları, Protokol Konuşmaları, Konferans ve Makaleleri. h. Ali Yıldırım, Yusuf Ziya Yağcıŏglu. Ankara: Diyanet İşleri Başkanlığı Yayınları, 1995.

DİB, Diyanet İşleri Başkanlığı. Diyanet İşleri Başkanı Mehmet Nuri Yılmaz'ın Konuşmaları ve Makaleleri. Ankara: Diyanet İşleri Başkanlığın Yayınları, 1-7 cilt, 19962002. 
DİB, Diyanet İşleri Başkanlığı. 2006 Faaliyet Raporu. Ankara: Diyanet İşleri Başkanlığı Yayınları, 2007.

DİB, Diyanet İşleri Başkanlığı. 2007 Faaliyet Raporu. Ankara: Diyanet İşleri Başkanlığı Yayınları, 2008.

DİB, Diyanet İşleri Başkanlığı. 2010 Faaliyet Raporu. Ankara: Diyanet İşleri Başkanlığı Yayınları, 2010.

DİB, Diyanet İşleri Başkanlığı. 2011-2013 Yilları Faaliyetler ve Raporlar. Ankara: Diyanet İşleri Başkanlığı Yayınları, 2013.

$\begin{array}{llll}\text { DIBB, Diyanet İşleri } \quad \text { Başkanlığı. Hutbe. } & \text { 03.02.2017. }\end{array}$ https://www.diyanet.tv/cuma-hutbesi-canli-cuma-sevinci/video/cuma-hutbesi-3subat-2017.

Din İşleri Yüksek Kurulu, Fetvalar. Ankara: Diyanet İşleri Başkanlığı Yayınları, 4. Bask1, 2018.

Diyanet. “Başyazı”. Diyanet Gazetesi 188-349 arası (Mayıs 1978 - Mart 1988) 150 sayıdan 6 sayı.

DİYK, Din İşleri Yüksek Kurulu. K.1993/6 (03 Şubat 1993). https://kurul.diyanet.gov.tr/Karar-Mutalaa-Cevap/2471/tesettur-ile-ilgili-karar.

DİYK, Din İşleri Yüksek Kurulu. K. 1997/130 (04 Aralık 1997). https://kurul.diyanet.gov.tr/Karar-Mutalaa-Cevap/2610/turkce-ibadet-meselesi.

DİRTV, Diyanet İşleri Reisliği Teşkilat ve Vazifeleri Hakkındaki Kanun. Resmî Gazete 3035 (22 Haziran 1935), Kanun No: 2800, ( 5376-5377). Erişim 03 Eylül 2021. https://www.resmigazete.gov.tr/arsiv/3035.pdf. 1972).

Doğan, Lütfi. “Başyazı”. Diyanet Gazetesi 1-50 arası 47 sayı. (Kasım 1968- Eylül

Doğan, Lütfi. “Başlarken”. Diyanet Gazetesi 1 (1968), 1,16.

Doğan, Lütfi. Toplumun Temelini Sarsan Belli Başlı Problemler (Huzur ve Saadetin Esasları). Ankara: Diyanet İşleri Başkanlığı Yayınları, 10. Baskı, 2016.

Doğan, Dr. Lütfi. “Başyazı”. Diyanet Gazetesi 51-146 92 sayı. (Kasım 1968- Eylül 1972-A ğustos 1976).

Doğanay, Eraslan. Anadolu'da Yaşayan Dergahlar. İstanbul: Can Yayınları, 2000.

Duman, Önder - Aydın Mehmet. “27 Mayıs'ın Gölgesinde Bir “İrtica” Hamlesi: Türkçe Ezan". Uluslararası Tarih Araştırmaları Dergisi 11/6 (2019), 2265-2279.

Dursun, Davut. Yönetim-Din İlişkileri Açısından Osmanlı Devletinde Siyaset ve Din. İstanbul: İşaret Yayınları, 2. Baskı, 1992.

Erbaş, Ali. “Başyazı”. Diyanet Aylık Dergi 322-362. ( Ekim 2017 - Ağustos 2021). 
Ersal, Mehmet. Alevilik Kavramlar ve Ocak Sistemi -Çubuk Havzası Örneği-. Ankara: Türk Kültürü ve Hacı Bektaş Veli Araştırma Merkezi Yayınları, 2016.

Erşahin, Seyfettin. "Bir Cumhuriyet Kurumu Olarak Diyanet İşleri Başkanlığının Tarihi Kökeni (Ümmet Yapısından Millet Yapısına)". Din Hizmetleri ve Din Eğitiminde Türkiye Tecrübesi. 9-45. Ankara: Diyanet İşleri Başkanlığı Yayınları, 2019.

Fayda, Mustafa. "Hulefâ-yi Râşidîn". Türkiye Diyanet Vakfı İslâm Ansiklopedisi. 18: 324-338. İstanbul: TDV Yayınları, 1998.

Gez, Başak Ocak. "İbadet Dilinin Türkçeleştirilmesi Aşamalarından Biri: Türkçe Ezan ve Uygulamaları". Çă̆daş Türkiye Tarihi Araştırmaları Dergisi 2/6-7 (1996-1997), 157-167.

Göl, Yavuz Selim. "Abbasîler Döneminde Kâd1-'1-Kudâtlık”. Karadeniz Teknik Üniversitesi İlahiyat Fakültesi Dergisi 5/1 (2018), 11-59.

Görgülü, Faruk. "Dinî Dergicilik ve Süreli Yayınlarımız". Diyanet Aylık Dergi 300 (Ankara: Diyanet İşleri Başkalığı Yayınları, 2015), 24-26.

Görmez, Mehmet. "Başyazı". Diyanet Aylık Dergi 240-319. (Aralık 2010 Temmuz 2017).

Gözaydın, İştar. Diyanet Türkiye Cumhuriyeti'nde Dinin Tanzimi. İstanbul: İletişim, 2020.

Güler, Halit. “Başyazı”. Diyanet Gazetesi 188-349 arası (Mayıs 1978 - Mart 1988) 150 sayıdan 9 sayı.

Gürtaş, Ahmet. "Başyazı". Diyanet Gazetesi 188-349 arası (Mayıs 1978 - Mart 1988) 150 sayıdan 3 sayı.

İğde, Muhyeddin. "Selefiliğin Tarihi Arka Planı".e-Makâlât Mezhep Araştırmaları 8/2 ( 2015), 151-181.

İnalcık, Halil. "Kanunnâme”. Türkiye Diyanet Vakfı İslâm Ansiklopedisi. 24: 333337. İstanbul: TDV Yayınları, 2001.

İpşirli, Mehmet. “Osmanlılar: Siyâsî ve İdârî Teşkilat: Klasik Dönem”. Türkiye Diyanet Vakfı İslâm Ansiklopedisi. 33: 502-505. İstanbul: TDV Yayınları, 2007.

İpşirli, Mehmet. "Şeyhlisâm”. Türkiye Diyanet Vakfı İslâm Ansiklopedisi. 39: 9196. İstanbul: TDV Yayınları, 2010.

İsimsiz. “Başyazı”. Diyanet Gazetesi 259-382 arası (Ocak 1989 - Aralık 1990) 24 sayıdan 1 sayı.

Kalayc1, Mehmet. "Eşarilik". İslam Mezhepleri Tarihi. Ed. Hasan Onat-Sönmez Kutlu. 395-422. Ankara: Grafiker Yayınları, 2. Baskı, 2013. 
Kalaycı, Mehmet. "Mâtürîdî-Hanefî Aidiyetin Osmanlı'daki İzdüşümleri", Cumhuriyet İlahiyat Dergisi 20/2 (2016), 9-72.

Kara, İsmail. Türkiye'de İslâmcılık Düşüncesi. 2 cilt. İstanbul: Risale , 2. Baskı, 1987.

Kara, İsmail. “Din ile Devlet Arasında Sıkışmış Bir Kurum: Diyanet İşleri Başkanlığı". Marmara Üniversitesi İlahiyat Fakültesi Dergisi 18 ( 2000), 29-55.

Kara, Mustafa. Tasavvuf ve Tarikatlar Tarihi. İstanbul: Dergah Yayınları, 1990.

Karslı, Bahset. “Cumhuriyet Dönemi Din-Siyaset Tartışmaları: Ahmet Hamdi Akseki Örneği". Turkish Studies Türkoloji Araştırmaları 9/5 (2014), 279-1298.

Kaya, İsmail. "Makrososyolojik Perspektife Göre İslam Tarihinde Din ve Devlet İlişkisi Modelleri". Tokat İlmiyat Dergisi [Gaziosmanpaşa Üniversitesi Illahiyat Fakültesi Dergisi] 8/1 (2020), 403-428.

Kaya, Remzi. Sosyolojik Açıdan Türkiye'de Din-Devlet İlişkileri ve Diyanet İşleri Başkanlığı. İstanbul: İstanbul Üniversitesi, Sosyal Bilimler Enstitüsü, Doktora Tezi, 1994.

Kaydu, Ekrem. “Osmanlı Devletinde Şeyhülislâmlık Müessesesinin Ortaya Çıkışı”. Atatürk Üniversitesi İslâmî İlimler Fakültesi Dergisi 2 (1977), 201-210.

Kazıcı, Ziya. “Osmanlılarda Şeyhülislâmlık Müessesesi”. İslâm Medeniyeti 5/2 (1981), 39-68.

Keleş, Ekrem. “Başyazı”. Diyanet Aylık Dergi 320-321. (A ğustos 2017 - Eylül 2017).

Kılıç, Murat. “Cumhuriyet'in İlk Yıllarında Devlet ile Vatandaş Arasında Bir İletişim Aracı Olarak Hutbeler". Çă̆daş Türkiye Tarihi Araştırmaları Dergisi 17/35 (2017), 137-166.

KHK 703, Anayasada Yapılan Değişikliklere Uyum Sağlanması Amacıyla Bazı Kanun ve Kanun Hükmünde Kararnamelerde Değişiklik Yapılması Hakkında Kanun Hükmünde Kararname (Kararname No: 703). Resmî Gazete 30473 (3. Mükerrer) (09 Temmuz 2018), KHK No: 703, m. 141. Erişim 5 Eylül 2021. https://www.resmigazete.gov.tr/eskiler/2018/07/20180709M3.pdf.

Koca, Fatih. Íslam Medeniyetinde Salâ ve Salavat Geleneği -Anadolu Örneği-. Ankara: Diyanet İşleri Başkanlığı Yayınları, 2. Baskı, 2017.

Koç, Ahmet. "Diyanet İşleri Başkanlığı ve Yaygın Din Eğitimi”. Din Hizmetleri ve Din Eğitiminde Türkiye Tecrübesi. 113-172. Ankara: Diyanet İşleri Başkanlığı Yayınları, 2019.

Koç, Turan. Din Dili. İstanbul: İz Yayıncılık, 1998. 
Koşum, Adnan. “Osmanlı Örfi Hukukunun İslam Hukukundaki Temelleri”. Selçuk Üniversitesi İlahiyat Fakültesi Dergisi 17 (2004), 145-160.

Köprülü, M. Fuad. “Ortazaman Türk Hukuki Müesseseleri”. İkinci Türk Tarih Kongresi: İstanbul 20-25 Eylül 1937 Kongrenin Çalışmaları, Kongreye Sunulan Tebliğler. 383-418. İstanbul: Kenan Matbaası, 1943.

Köprülü, M. Fuad. “Türkiye'de Âmme İdaresinin İnkişafı”. Haz. Orhan F. Köprülü. Türk Kültürü 12/ 255 (1984), 434-440.

Kuruluşundan Günümüze Diyanet İşleri Başkanlı̆̆ı Tarihçe-Teşkilat-Hizmet ve Faaliyetler (1924-1997). Ankara: Diyanet İşleri Başkanlığg Yayınları, 1999.

Kutlu Doğum Haftası İle Camiler Ve Din Görevlileri Haftasını Kutlama Yönetmeliğinde Değişiklik Yapılmasına Dair Yönetmelik. Resmî Gazete 30255. 29 Kasım 2017.

Kutlu, Sönmez. İslam Düşüncesinde İlk Gelenekçiler Hadis Taraftarlarının İman Anlayışı Bağlamında Bir Zihniyet Analizi. Ankara: Kitâbiyât, 2000.

Kutlu, Sönmez. "Bilinen ve Bilinmeyen Yönleriyle Imam Mâturîdî", İmam Mâturîdî ve Maturidilik. 17-55. Ankara: Kitâbiyât, 2003.

Kutlu, Sönmez. Alevîlik-Bektaşîlik Yazıları, Alevîliğin Yazılı Kaynakları, Buyruk, Tezkire-i Şeyh Safí. Ankara: Ankara Okulu Yayınları, 2008.

Kutlu, Sönmez. Mezhepler Tarihine Giriş. İstanbul: Dem Yayınları, 2008.

Kutlu, Sönmez. “Diyanet İşleri Başkanlığı ve İslamiçi Dini Gruplarla (Mezhep ve Tarikatlar) İlişkileri”, Din̂̂ Araştırmalar 12/33 (2009), 107-128.

Mert, Hamdi. “Başyazı". Diyanet Gazetesi 188-349 arası (Mayıs 1978 - Mart 1988) 150 sayıdan 36 sayı; 259-382 arası (Ocak 1989 - Aralık 1990) 24 sayıdan 2 sayı.

Okumuş, Ejder. “Din-Devlet İlişkilerine Meşruiyet Kavramı Etrafında Bir Yaklaşım". Marife: Dini Araştırmalar Dergisi 1/3 (2002), 7-29.

Okumuş, Ejder. “Dindarlık ve Diyanet”. Eski Yeni: Üç Aylık Düşünce Dergisi 10 (2008), 39-44.

Okur, Kâşif Hamdi. “Ebu Hanife ve Ana Dilde İbadet". İslâmî Araştırmalar 15/1-2 [Ebû Hanîfe Özel Sayısı] (2002), 83-90.

Okur, Kaşif Hamdi. "İslam Hukukunda Çağdaşlaşma Arayışlarının Arka Planı: Son Dönem Osmanlı Düşüncesinden Günümüze Uzanan Süreç". İslâmî İlimler Dergisi 3/1 Fıkıh Sayısı (2008), 155-174.

Okur, Kaşif Hamdi. "Son Dönem Osmanlı Düşüncesinde Fıkıh Alanındaki Tartışma ve Yaklaşımlar". Türkiye Araştırmaları Literatür Dergisi 12/23 (2014), 9-31. 
Okutan, Ahmet. "Başyazı". Diyanet Gazetesi 259-382 arası (Ocak 1989 - Aralık 1990) 24 sayıdan 1 sayı.

Onat, Hasan. "Değişim Sürecinde Alevîlik". Prof. Dr. Hasan Onat. Erişim adresi: http://www.hasanonat.net/index.php/99-degisim-suerecinde-alevilik.

Onat, Hasan. “Kızılbaşlık Farklılaşması Üzerine”. İslamiyat 6 /3 (2003), 111-126.

Onay, Ahmet. “Diyanet Hutbelerinin Muhteva Analizi: Diyanet İşleri Başkanlığının 1999 Yılı Hutbeleri Örneği”. İslâmî Araştırmalar 17/1 (2004), 1-13.

Öz, Baki. Dünyada ve Türkiye'de Alevi-Bektaşi Dergâhları. İstanbul: Can Yayınları, 2001.

Öz, Mustafa -i̇lhan, Avni. "İmâmet”. Türkiye Diyanet Vakfı İslâm Ansiklopedisi. 20: 201-203. İstanbul: TDV Yayınları, 1998.

Özcan, Azmi. "Hilâfet: Osmanlı Dönemi". Türkiye Diyanet Vakfı İslâm Ansiklopedisi. 17:546-553. İstanbul: TDV Yayınları, 1998.

Özcan, Nuri. “Kültür ve Geleneğimizde Teravih Namazı-Mûsiki İlişkisi”. Din ve Hayat: İstanbul Müftülü̆̆̈̈ Dergisi 5 (2008), 60-63.

Özdemir, Şuayip. “Avrupa Birliğine Giriş Sürecinde Alevilerin Diyanet İşleri Başkanlığında Temsil Meselesine Bakışı -Malatya Örneği-". Uluslararası Bektaşilik ve Alevilik Sempozyumu -I-. 441-454. Isparta: Isparta İlahiyat Fakültesi Yayınları, 2005.

Özkan, Mustafa. Dört Halife ve Emevîler Döneminde Din Devlet İlişkisi. Ankara: Araştırma Yayınları, 2015.

Rençber, Fevzi. Tarihsel ve Kültürel Boyutlarıla Alevîlikte Cem ve Cem Evleri. Şırnak: Şırnak Üniversitesi Yayınları, 2018.

Salman, Yüksel. “Diyanet İşleri Başkanlığı Yayınlarında Kadın”. Türkiye V. Dini Yayınlar Kongresi-Kadın Konulu Dini Yayınlar -Tebliğler-Müzakereler. 399-407. Ankara: Diyanet İşleri Başkanlığg Yayınları, 2012.

Sarıkaya, Mehmet Saffet. Anadolu Alevîliğinin Tarihî Arka Planı (XI-XIII. Yüzyıl)T. İstanbul: Ötüken Yayınları, 2003.

Sarıkaya, Mehmet Saffet. "Alevilik-Bektaşiliğin Tasavvufi Boyutu Üzerine”. Türk Kültürü ve Hacı Bektaş Veli Araştırma Dergisi 82 (2017), 9-23.

Sarıkaya, Mehmet Saffet - Ceylan, Mustafa. "Şeyh Çakır Ocağı Mensuplarının İnanç Esasları ve İbadetler Hakkındaki Kabulleri". Süleyman Demirel Üniversitesi Ilahiyat Fakültesi Dergisi 40 (2018/1), 173-202.

Sarıkaya, Mehmet Saffet. “Diyanet İşleri Başkanlığı Yayınlarında Mezhebî Tutum ve Eğilimler". İslâmi Araştırmalar 29/2 (2018), 268-287.

Sevgin, Halil. "Başyazı". Diyanet Gazetesi 188-349 arası (Mayıs 1978 - Mart 1988) 150 sayıdan 9 sayı. 
Şen, Mehmet Emin. "Abbâsîler Döneminde İdarî ve Malî Kadrolardaki Türkler". ISTEM: İslâm San'at, Tarih, Edebiyat ve Mûsikîsi Dergisi 7/13 (2009), 233-260.

Şentürk, Lütfi. “Başyazı”. Diyanet Gazetesi 188-349 arası (Mayıs 1978 - Mart 1988) 150 sayıdan 15 sayı.

Taş, Kemaleddin. Türk Halkının Gözüyle Diyanet. İstanbul: İz Yayıncılık, 2002.

Taş, Kemalettin. “Osmanlı Yönetim Sisteminde Şeyhülislamlık Kurumu Sosyolojik Bir Çözümleme-". Süleyman Demirel Üniversitesi Sosyal Bilimler Enstitüsü Dergisi 1/1 (2005), 81-102.

Taşğın, Ahmet. “1980 Sonrası Alevilerin Farklı Bir Görüntüsü: Alevi Caferiler ve Aşura Dergisi”. Dinî Araştırmalar 7/18 (2004), 141-148.

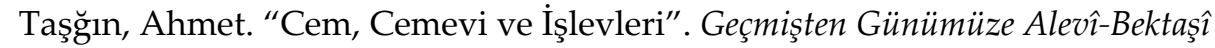
Kültürü. ed. Ahmet Yaşar Ocak. 211-225. Ankara: T.C. Kültür ve Turizm Bakanlığ1 Yayınları, 2009.

Teber, Ömer Faruk. Bektâşî Erkânnâmelerinde Mezhebi Unsurlar. Ankara: Aktif Yayınları, 2008.

Teber, Ömer Faruk. "Mezhebî Ayrışmanın Politik Sonuçları: Safevî Tarikatının Siyasallaşması". Ilahiyat Akademi: Altı Aylık Uluslararası Akademik Araştırma Dergisi 5 (2017), 193-200.

T.C. Anayasası, Türkiye Cumhuriyeti Anayasası (1961, Kanun No: 334). Resmî Gazete $10859 \quad$ (20 Temmuz 1961). Erişim 5 Eylül 2021. https://www.resmigazete.gov.tr/arsiv/10859.pdf.

T.C. Anayasası, Türkiye Cumhuriyeti Anayasası (1982, Kanun No: 2709). Resmî Gazete 17863 (Mükerrer) (09.11.1982). Erişim 5 Eylül 2021. https://www.resmigazete.gov.tr/arsiv/17863 1.pdf.

Türkiye'de Dini Hayat Araştırması. h. Diyanet İşleri Başkanlığı. Ankara: Türkiye Diyanet Vakfı Yayınları, 2014.

Türkiye Diyanet Vakfı. Kurban. Erişim 27.11.2021. https://tdv.org/trTR/faaliyetlerimiz/kurban.

Uçar, Ramazan. “Alevî-Bektâşîlerin Diyanet İşleri Başkanlığı'nda Temsil Problemi Üzerine (Alan Araştırması)". Uluslararası Bektaşilik ve Alevilik Sempozyumu -I-. 455-466. Isparta: Isparta İlahiyat Fakültesi Yayınları, 2005.

Uludağ, Süleyman. İslâm Düşüncesinin Yapısı, Selef, Kelâm, Tasavouf, Felsefe. İstanbul: Dergâh Yayınları, 1979.

Uzunçarşılı, İsmail Hakkı. Osmanlı Devletinin İlmiye Teşkilatı. Ankara: Türk Tarih Kurumu Yayınları, 1984. 
Üçer, Cenksu. “Aleviliğin Neliği ve Şiilik (Caferilik) ile İlişkisinin Çerçevesi". Marife: Dini Araştırmalar Dergisi 8/3 (2008), 205-238.

Üçer, Cenksu. “Cemlerde Kur'an'ın Türkçe Meâlinin Okunması Üzerine Bazı Mülâhazalar". Türk Kültürü ve Hacı Bektaş Veli Araştırma Dergisi 84 (2017), 61-91.

Üçer, Cenksu. "Alevî Nitelemeli Ocak/Gruplara Ait Tekke, Zâviye ve Dergâhlardaki Cami ve Mescidler". e-Makâlât Mezhep Araştırmaları 11/2 (2018), 271307.

Üçer, Cenksu, “Cemevi: Âdâb ve Erkânın İcrâ Edildiği Mekân”. Türk Kültürü ve Hacı Bektaş Veli Araştırma Dergisi 88 (2018), 59-84.

Üçer, Cenksu. "Alevî Nitelemeli Gelenek ya da Ocak ve Gruplar Hakkında Yapılacak Çalışmalarda Ocak Sisteminin Dikkate Alınmasının Önemi". e-makâlât Mezhep Araştırmaları 12/2 (2019), 353-402.

Üçer, Cenksu. Anadolu'da Alevî Ocakları ve Grupları. Ankara: Ankara Okulu Yayınları, 2020.

Üçer, Cenksu - Çelebi, Hatice Kübra. “Diyanet Aylık Dergi ile Başyazılarının Gündem Konuları ve Başyazılarda Yer Verilen Kur'an Ayetleri Üzerine Bazı Değerlendirmeler". Journal of Analytic Divinity 5/2 (2021), 134-172.

Üzüm, İlyas. "Alevilerin Caferi Mezhebine Mensubiyetinin Arka Planı: Alevilik-Caferilik İlişkisi veya İlişkisizliği”. İslâmiyât 4/3 (2003), 127-150.

Yaman, Ahmet. “Osmanlı Pozitif Hukukunun Şer'îliği Tartışmalarına Eleştirel Bir Katkı". İslâmiyat 8/1 (2005), 113-125.

Yaman, Ahmet. "Klasikler Üzerinden Ortak Bir Din Dili Oluşturulabilir mi?". Türkiye IV. Dini Yayınlar Kongresi: Dini Klasikler: Tebliğler-Müzakereler. 247-250. Ankara: Diyanet İşleri Başkanlığı Yayınları, 2011.

Yaman, Ahmet. “T.C. Diyanet İşleri Başkanlığı Din İşleri Yüksek Kurulunun Fetva Yöntemi". Din Hizmetleri ve Din Eğitiminde Türkiye Tecrübesi. 47-70 Ankara: Diyanet İşleri Başkanlığı Yayınları, 2019.

Yaman, Ahmet. "Riâsetü'ş-Şuûni'd-Dîniyye fî Türkiyâ Turuku ve Esâlîbu Isdâri'l-Fetâvâ min Kıbeli'l-Meclisi'l-E'lâ li'ş-Şuûni'd-Dîniyye". Mecelletü'dDiyâneti'l-'Ilmiyye bi'l-Lü̆gati'l-'Arabiyye/Diyanet Arapça İlmi Dergi 1 (2019), 61-95.

Yaman, Ali. Alevilikte Dedeler Ocaklar. İstanbul: Ufuk Matbaacılık, 1998.

Yaman, Mehmet. Alevîlik İnanç-Edeb-Erkân. İstanbul: 2001.

Yaman, Mehmet. Alevilikte Cenaze Hizmetleri. İstanbul: 1999.

Yavuzer, Hasan. Çă̆daş Din Hizmeti ve Diyanet İşleri Başkanlı̆̆ı-Dini Otorite ve Teşkilatların Sosyolojik Analizi. Kayseri: Laçin Yayınları, 2. Basım, 2006. 
Yavuzer, Hasan. “Diyanet İşleri Başkanlığı ve Din Hizmetleri”. Din Hizmetleri ve Din Eğitiminde Türkiye Tecrübesi. 73-111. Ankara: Diyanet İşleri Başkanlığ1 Yayınları, 2019.

Yazıc1, Seyfettin. “Başyazı”. Diyanet Gazetesi 259-382 arası (Ocak 1989 - Aralık 1990) 24 sayıdan 2 sayı.

Yazıcıŏlu, Mustafa Said. “Başyazı”. Diyanet Gazetesi 259-382 arası (Ocak 1989 - Aralık 1990) 24 sayıdan 6 sayı.

Yazıcıŏ̆lu, Mustafa Said. “Başyazı". Diyanet Aylık Dergi 1-13. (Ocak 1991Ocak 1992).

Yazıcıoğlu, Mustafa Said. “Başyazı”. Diyanet Aylık Dergi 1 (1991), I.

Yazıcıŏ̆lu, Mustafa Said. Ne Yan Yana Ne Karşı Karşıya Anılar. İstanbul: Alfa Yayıncılık, 2013.

Yıldırım, Ali. “Din Dili Dinî Dil Ayırımı”. Gaziosmanpaşa Üniversitesi Sosyal Bilimler Araştırmaları Dergisi 11/1 (2016), 323-330.

Yıldırım, Ramazan. “Sünni Siyaset Düşüncesinin Tarih İçindeki Gelişimi ve Etkinliği", İstanbul Üniversitesi İlahiyat Fakültesi Dergisi [Darulfunun İlahiyat] 24 (2011), 5-24.

Yıldız, Hakkı Dursun. "Abbâsîler". Türkiye Diyanet Vakfı İslâm Ansiklopedisi. 1: 31-48. İstanbul: TDV Yayınları, 1988.

Yılmaz, Mehmet Nuri. “Başyazı”. Diyanet Aylık Dergi 14-147. (Şubat 1992- Mart 2003).

Yılmaz, Ömer. Geçmişten Günümüze Tasavvuf ve Tarîkatlar. Ankara: Akçă̆ Yayınları, 2015.

Yücel, İrfan. “Diyanet İşleri Başkanlığının Tarihçesi”. Diyanet Aylık Dergi 41 (1994), 17-21.

Zafer, Cem. "Dinî Alanda Dilin Kullanımı ve Etkileri". Akademik Sosyal Araştırmalar Dergisi 7/89 (2019), 627-640.

Zengin, Sabri. "Zile'de Türkçe Ezana Tepki Olayı". Gaziosmanpaşa Üniversitesi Sosyal Bilimler Araştırmaları Dergisi 1 (2014), 167-180.

IX. Avrasya İslâm Şurası Sonuç Bildirgesi (14 Ekim 2016). https://avrasyaİslâmsurasi.diyanet.gov.tr/tr-TR/Declaration/ Detail/9. 
